

\begin{tabular}{|c|c|}
\hline REPORT DOCUMENTATION PAGE & $\begin{array}{c}\text { READ INSTRUCTIONS } \\
\text { BEFORE COMPLETING FORM } \\
\end{array}$ \\
\hline $\begin{array}{l}\text { 1. REPORT NUMBER } \\
\text { Miscellaneous Paper S-75-18 }\end{array}$ & 3. RECIPIENT'S CATALOG NUMBER \\
\hline \multirow[t]{2}{*}{$\begin{array}{l}\text { 4. TITLE (and Subtite) } \\
\text { AIR FIELD PAVEMENT CONSTRUCTION-SLIPFORM } \\
\text { PAVING METHOD }\end{array}$} & $\begin{array}{l}\text { 5. TYPE OF REPORT \& PERIOD COVERED } \\
\text { Final report }\end{array}$ \\
\hline & 6. PERFORMING ORG. REPORT NUMBER \\
\hline $\begin{array}{l}\text { 7. AUThOR(s) } \\
\text { Frazier Parker, Jr. }\end{array}$ & 8. CONTRACT OR GRANT NUMBER(s) \\
\hline $\begin{array}{l}\text { 9. PERFORMING ORGANIZATION NAME AND ADDRESS } \\
\text { U. S. Army Engineer Waterways Experimeńt Station } \\
\text { Soils and Pavements Laboratory } \\
\text { Vicksburg, Mississippi } 39180\end{array}$ & $\begin{array}{l}\text { 10. PROGRAMELEMENT, PROJECT, TASK } \\
\text { AREA \& WORK UNIT NUMBERS }\end{array}$ \\
\hline \multirow{2}{*}{$\begin{array}{l}\text { 11. CONTROLLING OFFICE NAME AND ADDRESS } \\
\text { Office, Chief of Engineers, U. S. Army } \\
\text { Washington, D. C. } 20314\end{array}$} & $\begin{array}{l}\text { 12. REPORT DATE } \\
\text { June } 1975\end{array}$ \\
\hline & 13. NUMBER OF PAGES \\
\hline \multirow{2}{*}{ 14. MONITORING AGENCY NAME Q ADDRESS(If different from Controlling Office) } & $\begin{array}{l}\text { 15. SECURITY CLASS. (of this report) } \\
\text { Unclassified }\end{array}$ \\
\hline & $\begin{array}{l}\text { 15a. DECLASSIFICATION/DOWNGRADING } \\
\text { SCHEDULE }\end{array}$ \\
\hline
\end{tabular}

Approved for public release; distribution unlimited.

17. DISTRIBUTION STATEMENT (of the abstract entered in Block 20, if different from Report)

18. SUPPLEMENTARY NOTES

19. KEY WORDS (Continue on reverse side if necessary and identify by block number)

Airfield pavements

Paving equipment

Rigid pavements

Slipform

20. ABSTRACT (Continue on reverse side if necessary and identify by block number)

This report presents the results of a study conducted to evaluate the use of slipform paving equipment for the construction of airfield pavements. Nine construction projects were observed and smoothness measurements made on eight of these projects. Currently used equipment and construction practices are presented and analyzed; problem areas and corrective measures are discussed. Results from the smoothness measurements are presented and considered in terms of current construction requirements and the effect of the surface smoothness on the functional performance of the pavement. Although the elimination of fixed side forms is the most appealing feature of the slipform method, it also causes the most complications. The sophisticated equipment and grade and alignment control systems require highly trained personnel. Large quantities of low-slump

(Continued) 


\section{ABSTRACT (Continued):}

concrete are needed to ensure uniform forward movement of the paver. It is also imperative that the concrete have a uniform consistency. The construction of keys and keyways and the installation of dowels in longitudinal construction joints require special techniques. The free-standing or slipformed edges will slump to a certain extent. The magnitude of edge slump is directly proportional to slab thickness. Edge slump results in deviations of the surface from a straightedge which are greater along paving lane edges than in the interior of the paving lanes. If uncontrolled, excessive edge slump can cause problems during the construction of fill-in lanes and can result in depressions along longitudinal construction joints. Within the interior of paving lanes, the smoothness of the surface is comparable in the longitudinal and transverse directions and appears to be independent of slab thickness. Slipform pavers can be used to construct airfield pavements that are structurally and functionally adequate for aircraft operation. However, it will require a concentrated effort on the part of the engineer and the contractor to ensure that the design and specifications, field adjustments, and quality control procedures result in a pavement with the desired characteristics. 
THE CONTENTS OF THIS REPORT ARE NOT TO BE USED FOR ADVERTISING, PUBLICATION, OR PROMOTIONAL PURPOSES. CITATION OF TRADE NAMES DOES NOT CONSTITUTE AN OFFICIAL ENDORSEMENT OR APPROVAL OF THE USE OF SUCH COMMERCIAL PRODUCTS. 


\section{PREFACE}

The investigation reported herein was sponsored by the Office, Chief of Engineers, as part of the "Engineer Criteria for Design and Construction" project and the "Short-Range Heavy-Duty Pavement Research Program."

The investigation was conducted during the period of July 1971-June 1973 under the supervision of Mr. J. P. Sale, Chief, Soils and Pavements Laboratory, U. S. Army Engineer Waterways Experiment Station (WES). This report was prepared by Dr. Frazier Parker, Jr.

Directors of WES during the investigation and the preparation and publication of this report were BG E. D. Peixotto, CE, and COL G. H. Hilt, CE. Technical Director was Mr. F. R. Brown. 
CONVERSION FACTORS, U. S. CUSTOMARY TO METRIC (SI) UNITS OF MEASUREMENT

PART I: INTRODUCTION

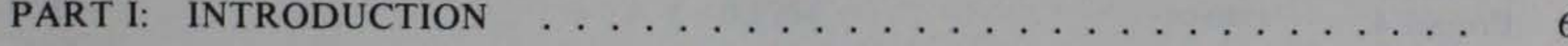

PART II: DESCRIPTION AND DEVELOPMENT OF SLIPFORM METHOD _. . . 7

Description of Method . . . . . . . . .......... 7

Historical Development of Method . . . . . . . . . . . . . . . . . . . . . . . . . 7

PART III: EQUIPMENT . . . . . . . . . . . . . . . . . . . . . . 9

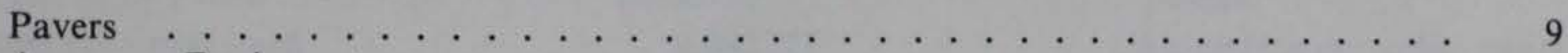

Accessory Equipment . . . . . . . . . . . . . . . . . . . . . 11

PART IV: FIELD OBSERVATIONS AND SMOOTHNESS MEASUREMENTS . . . 13

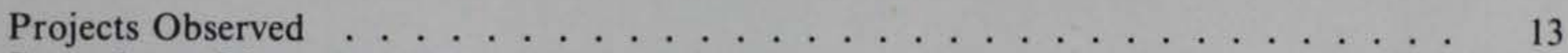

Smoothness Measurements . . . . . . . . . . . . . . 13

PART V: ANALYSIS OF CURRENT CONSTRUCTION PRACTICES . . . . . . . 15

Construction Sequencing . . . . . . . . . . . . . . . 15

Material Considerations . . . . . . . . . . . . . . . . . . 16

Preparation of Underlying Material . . . . . . . . . . . . . . . . 17

Grade and Alignment Control . . . . . . . . . . . . . . . . . . . . . . 17

Production and Transportation of Concrete . . . . . . . . . . . . . . . . . . 18

Distribution of Concrete . . . . . . . . . . . . . . . . . . . . . . 19

Placement of Reinforcing Steel . . . . . . . . . . . . . . . . . . . 19

Formation of Keyed or Keyed and Tied Longitudinal Joints . . . . . . . . . . . 20

Installation of Dowels . . . . . . . . . . . . . . . . . . . . 21

Manual Finishing and Surface and Edge Deficiency Correction . . . . . . . . . 21

PART VI: ANALYSIS OF SMOOTHNESS MEASUREMENTS . . . . . . . . . . . 23

Transverse Measurements . . . . . . . . . . . . . . . . . . . . 23

Longitudinal Measurements . . . . . . . . . . . . . . . . . . . 26

Smoothness Requirements . . . . . . . . . . . . . . . . . . . . . 27

PART VII: PROBLEM AREAS AND CORRECTIVE MEASURES ． . . . . . . . . 29

Problem Areas . . . . . . . . . . . . . . . . . . . . . . . . . . . . . . . . . . . . 29

Corrective Measures . . . . . . . . . . . . . . . . . . 32

PART VIII: CONCLUSIONS . . . . . . . . . . . . . . . . . . . 34

REFERENCES ............................. . . . . . . 35

TABLES 1 and 2

PHOTOS 1-25 


\section{CONTENTS}

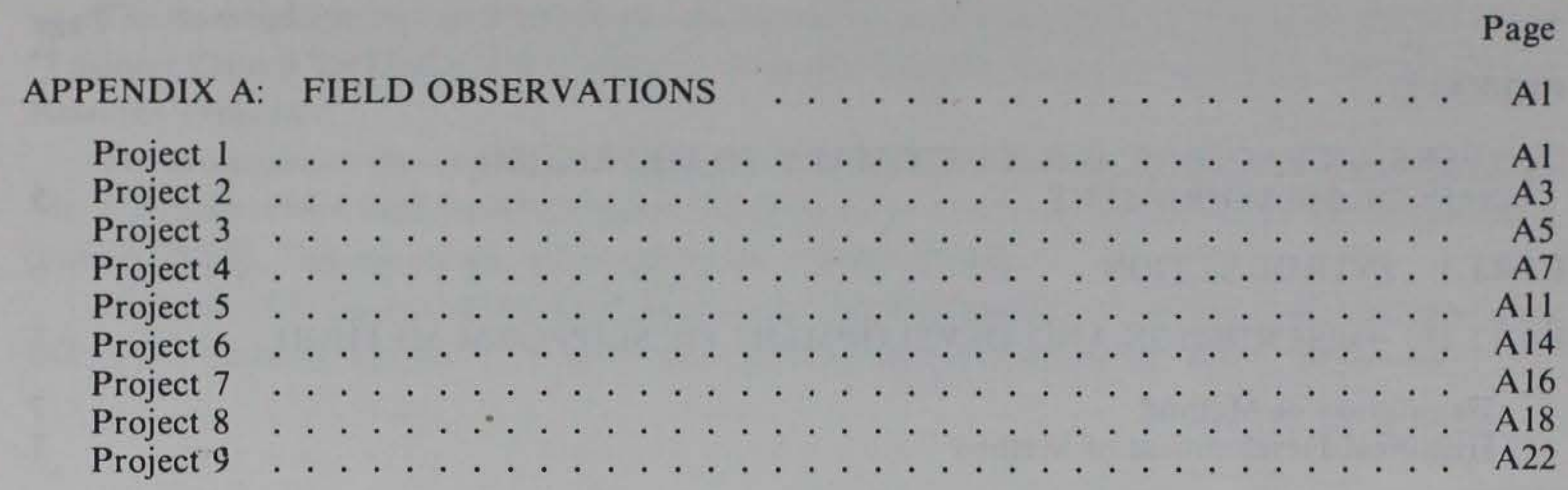




\section{CONVERSION FACTORS, U. S. CUSTOMARY TO METRIC (SI) UNITS OF MEASUREMENT}

U. S. customary units of measurement used in this report can be converted to metric (SI) units as follows:

Multiply

inches

feet

miles (U. S. statute)

pounds (mass)

cubic yards

kips

kips per square inch

pounds per cubic yard

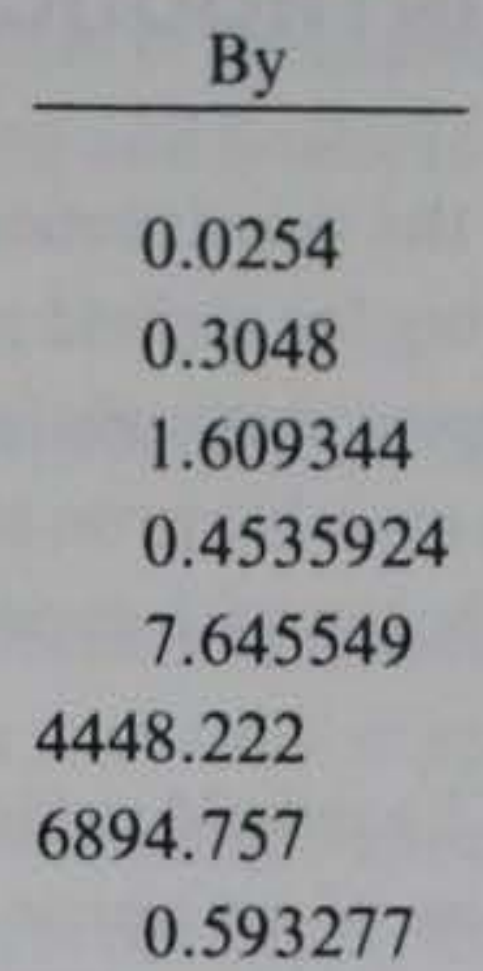

To Obtain 


\section{AIRFIELD PAVEMENT CONSTRUCTION- SLIPFORM PAVING METHOD}

\section{PART I: INTRODUCTION}

1. Slipform pavers have been used for the construction of portland cement concrete highway pavements since 1949. However, slipform paving for airfield pavement construction did not begin until 1960. During the sixties, slipform paving was used sparingly in the United States and Europe for airfield pavement construction; these pavements were mainly apron and taxiway pavements. In 1969, extensive use of slipform paving at commercial airports began with approval being granted for its use on a number of major construction projects.

2. The first major Corps of Engineers (CE) airfield paving contract permitting slipform paving as an alternate method was for the construction of an apron at Luke Air Force Base, Arizona. The pavement was constructed during the period September 1970-October 1971. Lack of CE interest during the 1960's was caused by several factors: the small amount of airfield pavement construction under way, and the failure of several trials to produce a pavement which, in the opinion of the contracting officer, met the required specifications. As a result, contractors were required to use forms in lieu of slipform pavers.

3. In $1970 \mathrm{CE}$ interest in slipform paving was regenerated by the identification of a major airfield pavement construction program and the recognition of potential savings which could be obtained by using slipform pavers. This renewed interest resulted in a study of the capabilities of current slipform paving equipment and techniques, the results of which are contained herein. 


\section{PART II: DESCRIPTION AND DEVELOPMENT OF SLIPFORM METHOD}

4. In this part the term "slipform paving" will be examined in an attempt to determine what is meant be the term. The historical development of the method will be briefly traced from its development to its use for highway pavement construction and finally to its use for construction of all types of airfield pavements.

\section{DESCRIPTION OF METHOD}

5. The term "slipform paving" undoubtedly originated because the short side forms on the paver did not remain in place but moved with the paver and slipped along the edges of the pavement as it was formed. Initially, the equipment had relatively long trailing forms as compared with today's machines. However, the term "slipform" can be thought of as applying to the top surface of the pavement as well as the edges, ${ }^{1}$ since the mechanism for shaping the surface also moves with the paver.

6. In addition to these features, Gillis and Spickelmire ${ }^{2}$ list and discuss a number of other characteristics which distinguish the method from fixed side form construction. Gillis and Spickelmire also list six types of pavers, each of which has some distinguishing feature. Although one could discuss semantics and the various processes at great lengths, if the term is accepted as somewhat of a misnomer and a discussion of the characteristics of different machines delayed, the general features of the method may be considered.

7. The term "slipform method" may be applied to the construction of pavement without the aid of stationary side forms. In addition, modern slipform pavers have the following characteristics:

a. They are self-propelled and crawler-mounted.

b. Horizontal and vertical alignment may be automatically controlled.

c. The machine is capable of spreading, consolidating, and shaping the concrete to the desired cross section in one pass. Spreading may be accomplished by a separate unit but, as defined, would be considered as a part of the paving operation.

d. The pavement, as formed, will require a minimum amount of hand finishing.

8. The preceding characteristics generally apply to all currently used slipform pavers. The two most important features are the elimination of the use of side forms and the formation of the pavement cross section in one pass of one machine.

\section{HISTORICAL DEVELOPMENT OF METHOD}

9. The following paragraphs, taken from References 2,3 , and 4, discuss the early development of slipform paving.

10. The development of the slipform paver is attributed to an Iowa State Highway Department Test Engineer, James W. Johnson. In 1946, Mr. Johnson built the first model paver, which placed a slab

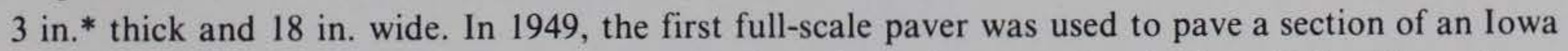
secondary road $1 / 2$ mile long, $20 \mathrm{ft}$ wide, and 6 in. thick; this paver placed a lane $10 \mathrm{ft}$ wide, and two

\footnotetext{
* A table of factors for converting U. S. customary to metric (SI) units of measurement is presented on page 5 .
} 
passes were necessary to complete the 20 - $\mathrm{ft}$ wide roadway. Later that year the machine was used to pave a section 1 mile long.

11. No further attempts were made to use slipform pavers until 1955 when the first production model paver was introduced by the Quad-Cities Construction Company. During the late 1950's and the 1960 's the use of slipform pavers for constructing highway pavements increased rapidly. According to Gillis and Spickelmire, ${ }^{1}$ approximately 10,000 lane miles of pavement had been constructed in the United States by 1965 . Needless to say, tremendous progress has been made to date in equipment and techniques. $^{5}$

12. A slipform paver was first used for airport pavement at Theodore E. Green Airport in Rhode Island in 1959.6 In 1964, several projects were constructed in France using a slipform paver. During the next four years (through 1968) several smaller projects were undertaken with slipform pavers. In 1969, runways in Atlanta, Georgia, and Palmdale, California, were constructed with slipform pavers. As mentioned earlier, most of the previous slipform pavements had been used on taxiways and aprons; a small portion were used on runways. These two jobs appeared to open the door for the use of slipform paving for all types of airfield pavements, and since that time, its use has been virtually universal. The acceptance of the method for airfield pavement construction and an indication of developments in equipment and techniques are clearly illustrated by the construction of the Dallas-Fort Worth Regional Airport. All of the pavements at this vast complex were constructed using slipform pavers, with one machine placing lanes $50 \mathrm{ft}$ wide.

13. In 1971, the Federal Aviation Administration (FAA) issued a change to their standard specification for construction of rigid pavement ${ }^{7}$ which permitted and provided guidance for using slipform paving equipment. In 1973, based on the results of the study reported herein, the Corps of Engineers Guide Specification-Military Construction-Concrete Pavement for Roads and Airfields ${ }^{8}$ was revised to provide for the use of slipform paving as an acceptable alternate and to provide guidance for its use. In addition, TM 5-822-7, "Standard Practice for Concrete Pavements," 9 was revised to reflect these changes. 


\section{PART III: EQUIPMENT}

14. In this part, the various types of slipform pavers currently used for airfield pavement construction will be considered. The distinguishing features of each will be noted and discussed. In addition, certain accessory equipment, such as spreaders, floats, and texturing devices, which have been developed along with the pavers, will be discussed.

\section{PAVERS}

15. Developments in slipform paving equipment have progressed, along with its use, from Mr. Johnson's manually controlled machine which could place a slab 6 in. thick and $10 \mathrm{ft}$ wide to today's modern automatically controlled machines that can place slabs approximately $20 \mathrm{in}$. thick and up to $50 \mathrm{ft}$ wide. During the developmental period a number of types of machines were developed by several companies. Gillis and Spickelmire ${ }^{2}$ describe six machines. Of these, three are currently being manufactured and marketed in quantity. These are machines produced by Guntert and Zimmerman Construction Division, Inc., CMI Corp., and Rexnord, Inc.

16. Guntert and Zimmerman slipform pavers (Photo 1) form the concrete to the desired cross section by: (a) vibrating the concrete until it becomes fluid and (b) confining the concrete, while it is in a maximum state of fluidity and density, with a large forming plate and the side forms until it reverts back to a nonfluid state. Final surface finish is applied with pan floats. Figure 1 illustrates the basic mechanisms for forming the pavement cross section. Since the process depends on the flow of the fluid concrete, it is important that the proper height or head of concrete be maintained in front of the forming plate. If the head is too small, the flow of the concrete will not be adequate to fill the confined space; if it is too large, the flow will be too large, causing surging behind the forming plate which will result in high spots in the pavement.

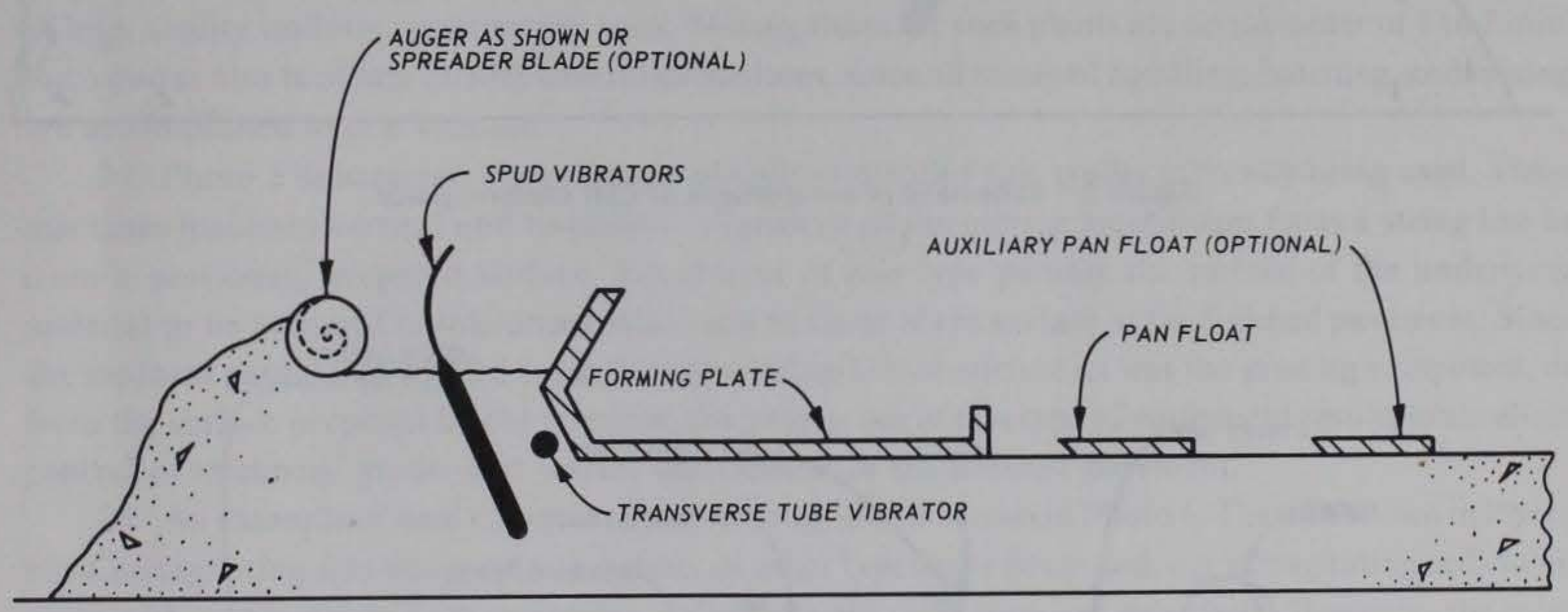

Figure 1. Schematic of components of Guntert and Zimmerman slipform paver

17. CMI slipform pavers (Photo 2) form the concrete to the desired cross section by (a) roughly forming the cross section by metering the flow of concrete under a strike-off; (b) consolidating the concrete with internal vibration and conditioning the surface with surface vibration; and (c) forming the 
surface by filling and cutting with dual oscillating extrusion screeds. Final surface finish is applied with a pan float. Figure 2 illustrates the basic mechanisms for forming the pavement cross section. Since the primary forming mechanism is provided by the dual oscillating screeds which cut and fill the surface, the surface of the concrete must be in a state where it can be manipulated by the screeds without tearing or disfiguring. Surface conditioning is accomplished by a secondary feed meter and grout circulator.

18. Rex slipform pavers (Photo 3 ) form the concrete to the desired cross section with a process which is similar in some respects to both the Guntert and Zimmerman and CMI machines. The cross section is formed by (a) striking off the concrete to roughly the desired cross section; (b) consolidating the concrete and conditioning the surface with internal vibrators and surface tampers; (c) confining the fluid concrete with a relatively large forming plate and the side forms until it reverts back to a nonfluid state. Final surface finish is applied with a pan float or oscillating belts. Figure 3 illustrates the basic mechanisms for forming the pavement cross section. The success of this process will depend on the ability of the equipment to condition the concrete so that it can be shaped by the large conforming plate.

19. While the three types of machines aforementioned are used for almost all airfield slipform paving, there are a number of smaller machines which may be used. There are slipform pavers which form such items as curbs, curbs and gutters, and median barriers. All the slipform pavers are basically

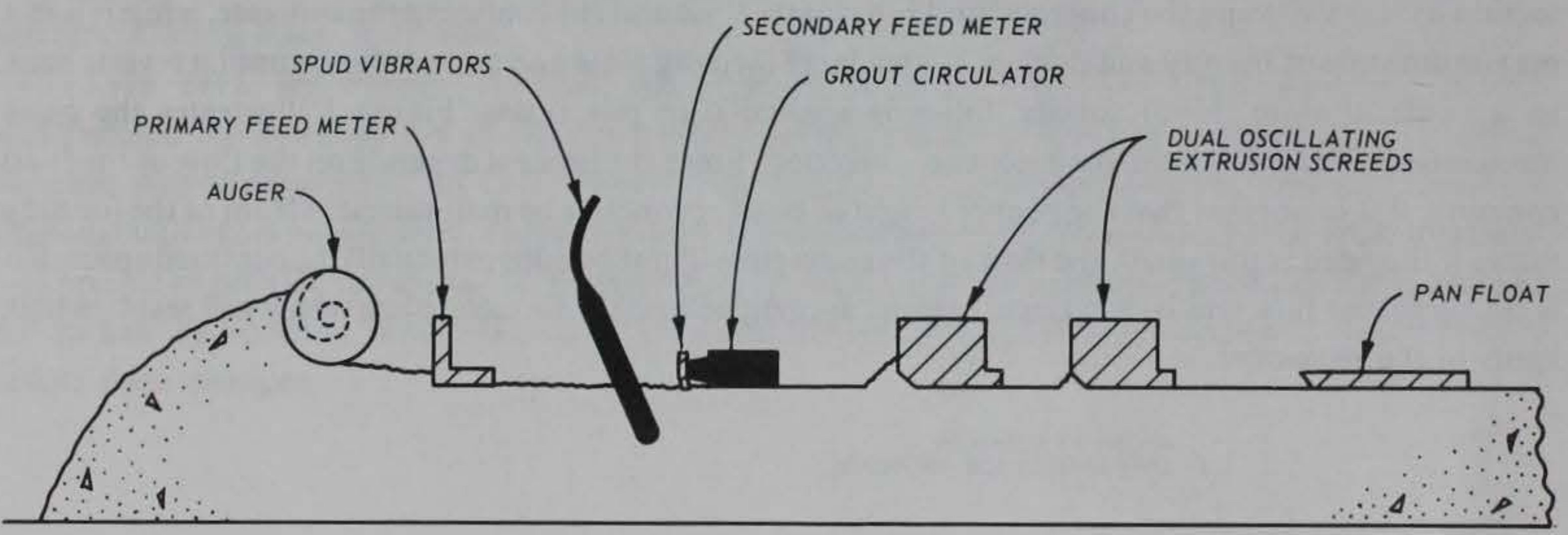

Figure 2. Schematic of components of CMI slipform paver

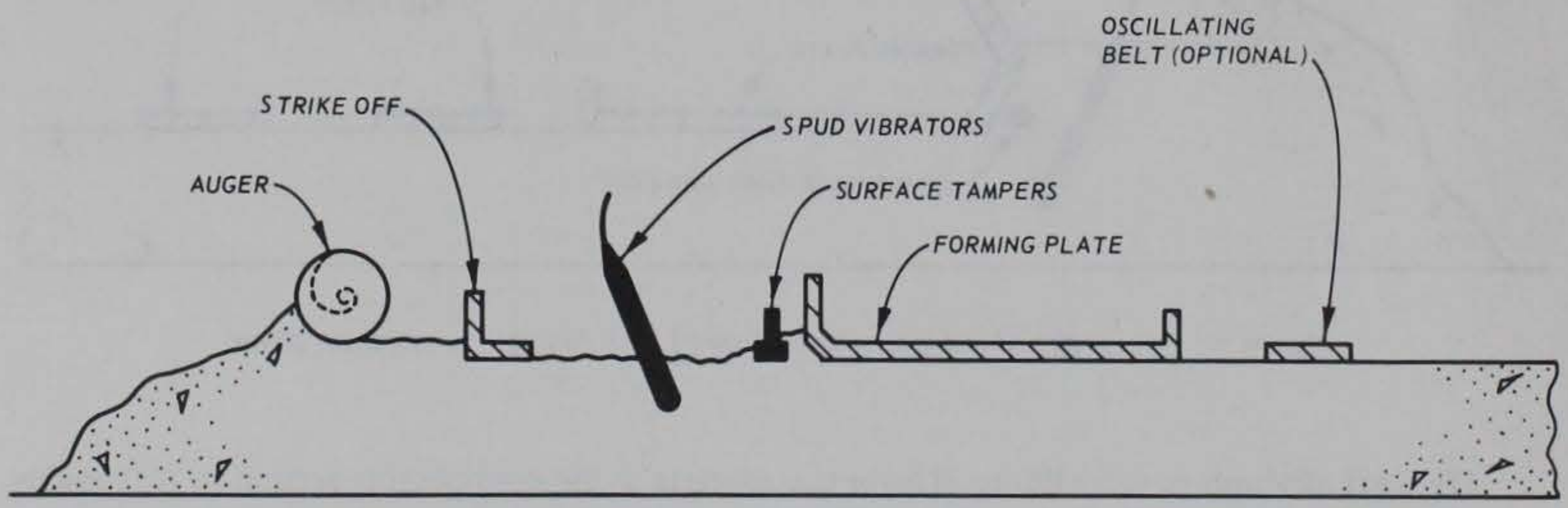

Figure 3. Schematic of components of Rex slipform paver 
alike in that the concrete is consolidated, the desired cross section formed, and the surface finished in one pass of the machine. If operated properly and if uniform concrete with the required consistency is provided, all of the machines have the capability of producing a pavement which requires a minimum amount of manual manipulation.

\section{ACCESSORY EQUIPMENT}

20. There are three primary reasons why new accessory equipment has been developed or modifications have been made to old equipment for use with slipform pavers: (a) the rate at which concrete can be placed with slipform pavers, (b) the uniformity from batch to batch required for proper placement with slipform paver, and (c) the absence of forms from which the equipment could operate. This last factor has lead to the development of automatically controlled fine graders and automatically controlled and self-propelled floats and cure-texture machines.

21. The need for large quantities of uniform concrete has resulted in the use of large central mix plants and large capacity, quick discharging haul trucks. Although the use of such equipment is not absolutely necessary from a strictly operational point of view, from the standpoint of quality of the finished product they are essential. Two of the most important factors in determining the quality of the finished pavement are the steady forward movement of the paver and the uniformity of the concrete as it reaches the paver.

22. At this point it may be advantageous to consider the size of paving jobs where a slipform paver will be used. The general rule would appear to be that any job which is large enough to warrant the use of a slipform paver would be large enough to warrant setting up a central mix plant and providing the specialized accessory equipment. For smaller jobs, particularly repair jobs, it may be advantageous to use less sophisticated equipment.

23. An example of the large mobile central mix plants being used in conjunction with slipform pavers is shown in Photo 4. These plants are highly mobile and permit the production of over 500 cu yd of high quality uniform concrete per hour. Mixing times for such plants are on the order of 1 to $2 \mathrm{~min}$. Such plants also facilitate quality control procedures, since all material handling, batching, and mixing are accomplished at one location.

24. Photo 5 illustrates a typical automatically controlled fine grader currently being used. These machines maintain vertical and horizontal alignment of the cutting mechanism from a string line or from a previously prepared surface. Equipment of this type permits the surface of the underlying material to be prepared to tolerances equivalent to those of the surface of the finished pavement. Since the slipform paver is controlled from the same string line or surface as was the grading equipment, or from the surface prepared by the trimmer, the proper use of this type of equipment results in excellent control of thickness, grade, and surface smoothness of the finished pavement.

25. An example of haul equipment that is being used is shown in Photo 6. The unit shown in Photo 6 is a nonagitating side-dump unit. A variety of other types have been used, e.g. nonagitating end-dump units with and without ejector systems, agitating units, and transient mix units. However, the most widely used appear to be the nonagitating end or side-dump units.

26. When it is possible to allow trucks to operate on the underlying material in front of a paver, the most desirable means for placing concrete is to have the haul trucks discharge onto the underlying material directly in front of the paver. However, this may not always be possible for a variety of reasons, e.g. instability of the underlying material, the installation of reinforcing steel, or the installation of dowels in transverse joints. In these instances, a spreader must transport the concrete from outside the 
paving lane to the paving lane interior. Photos 7-9 illustrate typical equipment currently used for this purpose. Photo 7 shows a belt spreader which is attached to the paver. Concrete is dumped from an enddump truck into a hopper and onto a series of conveyer belts which transport the concrete to the paving lane. The system of belts and chutes is articulated such that the end of the belt moves parallel to the front of the paver permitting the concrete to be spread uniformly across the paving lane. Photo 8 shows a spreader which employs both a conveyor belt and auger for spreading concrete across the paving lane. Concrete is deposited from end-dump trucks into a hopper and onto a conveyor belt. The belt transports the concrete to the interior of the paving lane. Final spreading is accomplished by augers. Photo 9 shows a box-type spreader. As concrete is dumped from side-dump trucks into the hopper of the spreader, the hopper moves across the paving lane depositing a strip of concrete. The height of the bottom of the hopper is adjusted to control the thickness of the strip of concrete flowing from the hopper.

27. A tube float is often used for final surface finishing. A typical self-propelled model is shown in Photo 10 . The aluminum tube is dragged longitudinally along the paving lane to correct minor surface deficiencies such as high or low spots and minor tears. The aluminum tube is usually oriented with the center line of the paving lane at an angle of 30 to $45 \mathrm{deg}$. The most common misuse of this piece of equipment is its overuse. Machines of this type are also used for applying burlap drag texture, and they often carry a roll of polyethylene for protecting the pavement surface against rain.

28. A device similar to that shown in Photo 11 is used to apply broom texture or wire comb texture to the surface; this machine can also apply curing compound.

29. There is a wide variety of equipment available. The choice of the type of equipment will depend to some extent on a contractor's personal preference and, to some extent, on the type of pavement to be constructed, construction requirements, and local conditions peculiar to a particular job. However, based on this study, the most significant finding concerning equipment is that each piece of available equipment will perform adequately if it is operated properly and used for the purpose for which it was designed. 


\section{PART IV: FIELD OBSERVATIONS AND SMOOTHNESS \\ MEASUREMENTS}

30. In this part, the field observation program will be considered. The features of each project observed and the surface smoothness measurements on each project will be discussed.

\section{PROJECTS OBSERVED}

31. The following field observations were made from August 1971 to January 1973. Nine projects were visited; smoothness measurements were made on eight of these. All but one of the projects were on airfield pavements, the one exception being a vehicular pavement on the interstate system.

32. Projects which would permit a wide range of variables to be studied were selected for observation. Special items of interest during the selection and subsequent inspection of projects were:

a. Projects being performed by both experienced and inexperienced contractors.

$b$. Projects with no reinforcing steel and those with various types of reinforcement.

c. Projects on which various types of transverse and longitudinal joints were constructed.

d. Projects on which a variety of types of batching, mixing, hauling, and paving equipment were used.

e. Projects on which a range of types of materials were used.

f. Projects constructed on a variety of foundation conditions.

g. Projects constructed under a range of climatological conditions.

33. Details of each project inspected are contained in the appendix to this report. For each project, there is a list of the details of the pavement construction and a summary of smoothness measurements taken; comments of the observers concerning the job are given also. A qualitative analysis, based on the observation of the construction projects, is contained in the following part covering current construction practices.

\section{SMOOTHNESS MEASUREMENTS}

34. Smoothness measurements were made at eight of the nine projects visited. Deviations of the pavement surface from a straightedge were determined. The distance from the bottom of the straightedge to the pavement surface was measured with a scale. The straightedge was placed parallel and perpendicular to the direction of the paving lane. For longitudinal measurements, the straightedge was placed along the edge and in the interior of paving lanes. For transverse measurements, the straightedge was placed with its end along the lane edges, across longitudinal construction joints, and in the interior of paving lanes. Photos 12-15 illustrate the procedures used in obtaining measurements and several of the straightedge positions for measuring edge slump.

35. The term "edge slump," as used in this report, refers to the deviation or the magnitude of deviation of the unsupported paving lane edge from its original shape. In Figure 4, the term "edge slump" refers to the change in the shape of the pavement edge from the original square shape to that shown, or to the magnitude of the downward movement of the corner $\left(\Delta_{\mathrm{e}}\right)$.

36. On five of the eight projects, measurements were made with a 12 -ft-long straightedge and on one project a 16-ft-long straightedge was used. On two projects, only edge slump measurements were 
made with a 4-ft-long straightedge. The measurements from each project are summarized in the appendix. Included in the summations are the number of measurements, the maximum and average deviations from the straightedge, and percentage of the deviations exceeding certain limits.

37. Transverse measurements are (a) measurements of deviation of the surface from the straightedge at the edge of a paving lane and (b) measurements within a lane exclusive of the deviation along the edge. Longitudinal measurements were made in the same manner as the transverse measurements within the interior of the paving lane. In addition, for transverse and longitudinal measurements, the percentage of measurements which exceed a certain deviation are computed with a base representing both the number of straightedge positions and the number of measurements (locations where the pavement surface deviates from the straightedge).

38. The manner in which measurements were made and summarized may be clarified by Figure 4 . In this sketch, the end of the straightedge is located at the edge of the paving lane. In some cases, when fill-in lanes were in place, the straightedge was placed with the center point of the straightedge at the longitudinal construction joint. The deviation $\Delta_{\mathrm{e}}$ is the deviation of the edge or, as defined, the edge slump. For the one straightedge position, the readings $\Delta_{1}$ and $\Delta_{2}$ represent two measurements or locations where the surface deviates from the straightedge within the interior of the paving lane. Longitudinal measurements are taken in the same way as $\Delta_{1}$ and $\Delta_{2}$.

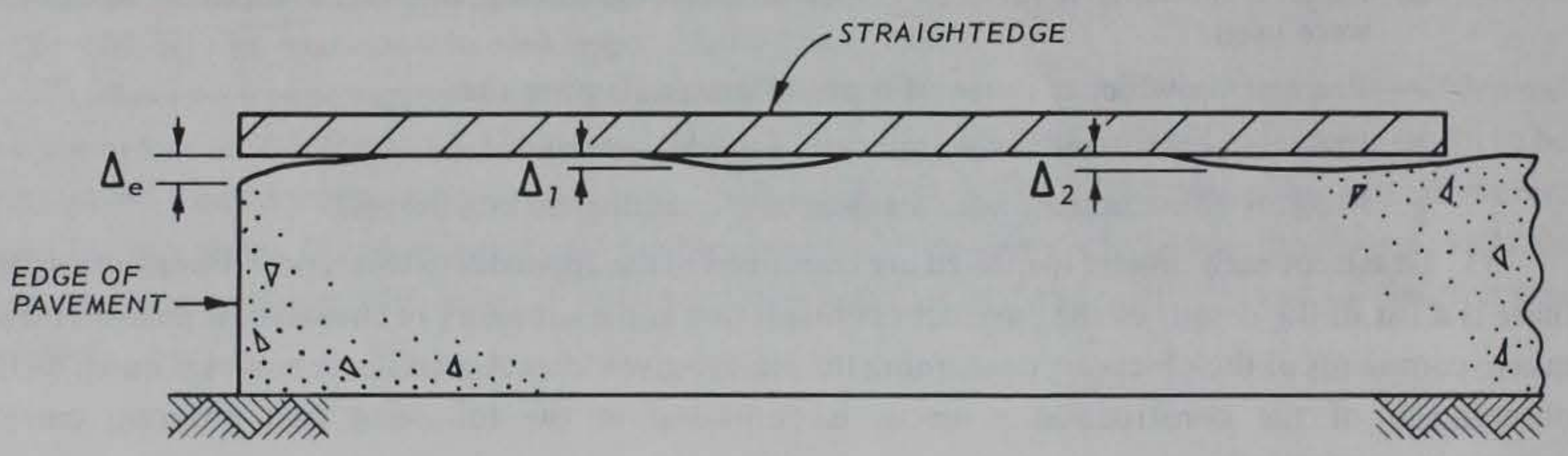

Figure 4. Placement of straightedge and measurement of deviation

39. No attempt was made to select particular areas on the pavement for taking measurements, rather, locations were selected at random. In some instances, a series of measurements were made at a particular location while, at others, only one was made. Deviations from the bottom edge of the straightedge were measured with a scale to the nearest sixteenth of an inch.

40. Surface texture, which included texture applied with a burlap drag, texture applied with a wire comb, and grooves applied with a rotating drum, made accurate measurements difficult. Because of the surface texture, it was difficult to seat the straightedge and the tip of the scale, and as a result, there was considerable scatter in the measurements. The precision of the measurements was also affected by the texture, i.e., more confidence could be placed in a measured deviation of $1 / 4$ in. than could be placed in a deviation of $1 / 8$ in. The difficulties encountered in obtaining valid measurements representative of the surface condition point out the need for standard equipment and procedures for obtaining surface smoothness measurements. The results from the smoothness measurements are analyzed in Part VI. 


\section{PART V: ANALYSIS OF CURRENT CONSTRUCTION PRACTICES}

41. In this part current practices employed during the construction of airfield pavements with slipform pavers will be discussed. The discussion is based on observations made during visits to the previously mentioned construction projects. While the procedures and techniques employed on a particular job depend on the requirements of that particular job and local conditions, there are certain requirements and conditions which are common to a number of jobs. A variety of procedures and techniques were observed on the jobs, but there are, no doubt, numerous workable procedures and techniques other than those considered herein.

\section{CONSTRUCTION SEQUENCING}

42. Because of material handling and equipment limitations, it is necessary to separate the area to be paved into strips. The sequence in which the strips are placed will depend on such factors as location of the concrete mix plant, the use of reinforcing steel, dowels in transverse joints, the use of the prepared surface for hauling concrete, etc.

43. A general rule in sequencing is that the longer sections, i.e., longer in the direction of paving, are paved first and shorter tie-in sections and miscellaneous odd-shaped and curved sections, which usually require handwork, are paved last. The longer portions of the three major areas on an airfield (apron, taxiway, and runway) would be constructed and then tied together. Where structures are encountered, such as buildings or drainage facilities, the pavement around these may be constructed first to provide a platform from which the paver can operate if horizontal clearance is a problem.

44. On an apron, the usual construction procedure is to slipform alternate lanes and then to fill in the space between. However, it is possible that there are circumstances where it would be advantageous to place successive lanes starting from the edge or the middle of the paved area. Both procedures result in the same number of free-standing edges, therefore, there is no inherent advantage to using either.

45. Runways are usually 150 or $200 \mathrm{ft}$ wide. Using pavers which place 25 -ft-wide strips, six or eight paving lanes are constructed. There are numerous sequences in which the lanes may be constructed, but the scheme selected usually involves either working from the middle to the edge or from the edge to the middle. Figure 5 illustrates two sequences used on two of the observed projects. During the construction

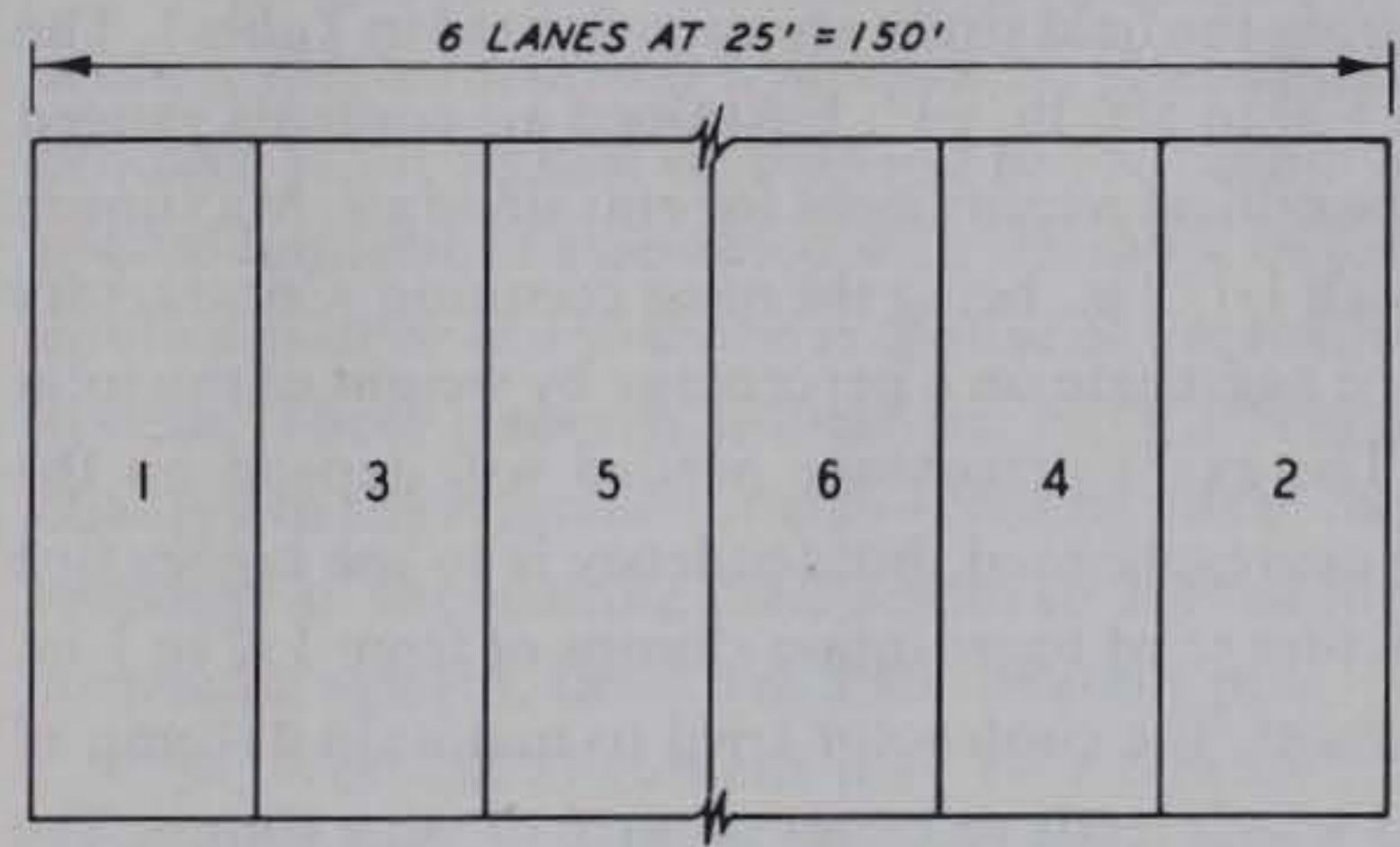

SCHEME 1

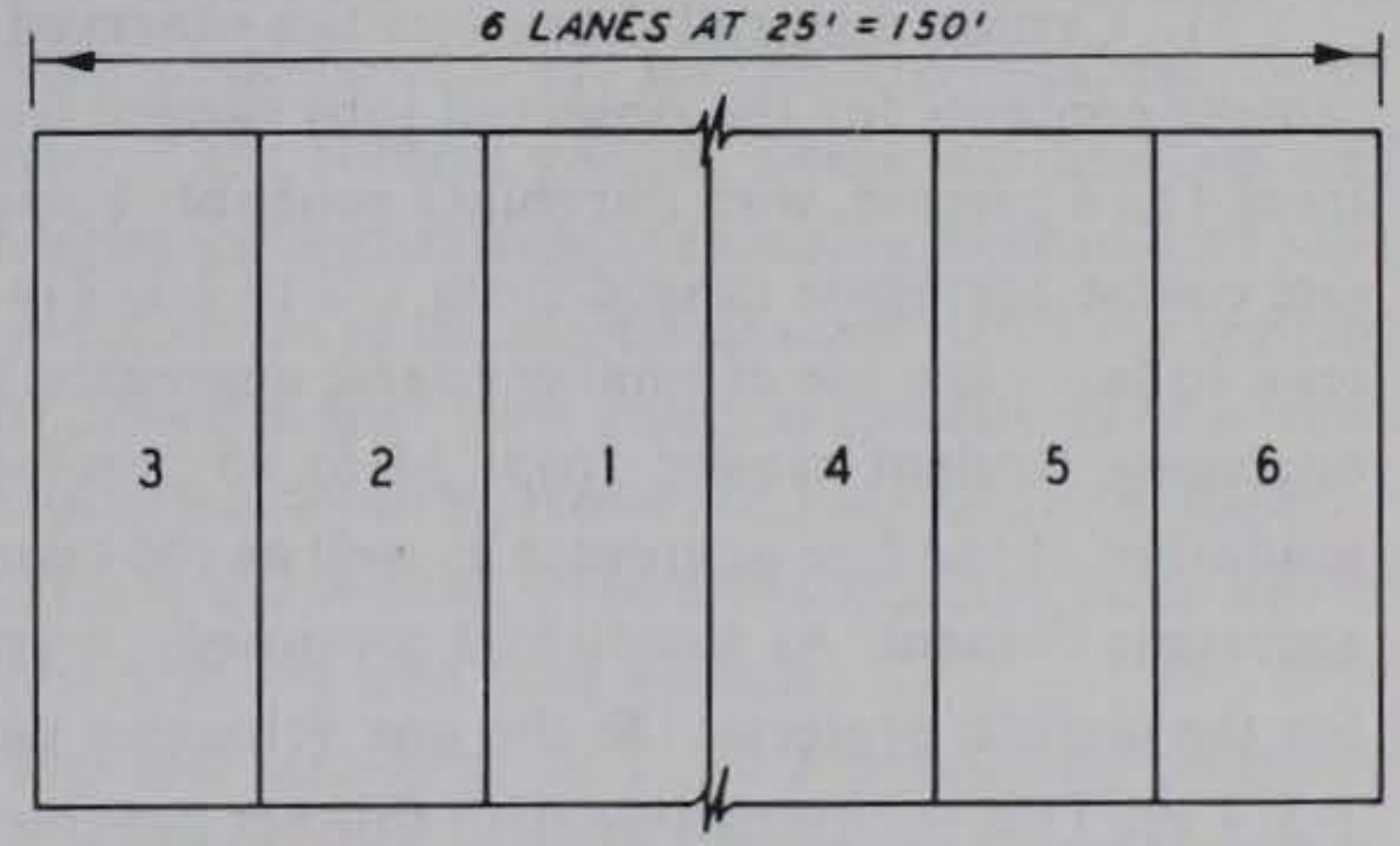

SCHEME 2

Figure 5. Typical sequence for lane construction of 150-ft-wide runway 
of the Dallas-Fort Worth Regional Airport, 200-ft-wide runways were constructed with four 50 -ft-wide lanes. The sequence used called for the construction of one of the inner lanes, the outer lane on the same side as the previously constructed inner lane, the other inner lane, and, finally, the other outer lane. There appears to be no inherent advantage to any sequence since the same number of free edges will result.

46. Taxiways are usually 75 to $100 \mathrm{ft}$ wide. The same principles are applicable to taxiways as were discussed for runways. However, on civil airports which usually have 75 -ft-wide taxiways, the most common sequence employed when 25 -ft-wide pavers are used involves slipforming the two outer lanes and filling in the center lane.

\section{MATERIAL CONSIDERATIONS}

47. When considering the properties of plastic concrete which are most critical to successful placement with slipform paving equipment, one property is always considered most important, the consistency of the concrete. With proper equipment adjustment, concrete with a fairly wide workability range can be placed. However, if the workability varies, proper placement cannot be obtained.

48. Slump, a measure of workability, is used to control the consistency of the concrete mix. For the thickness of airfield pavements it is usually necessary to maintain slumps between $1 / 2$ and 1-1/2 in. However, for vehicular pavements which are generally thinner, higher slumps may be used. For the eight airfield projects observed, all the contractors stated that they tried to maintain the slump between $1 / 2$ and $1 \mathrm{in}$. One contractor tried for $1 / 2$-in. slump, three for 3/4-in. slump, and four for 1 -in. slump.

49. Although the slump test is used as a measure of the workability of a mix, the correct proportions of all ingredients must be found which will result in plastic concrete that can be placed with slipform equipment. That is, a mixture must be found which can be formed to the desired pavement cross section without tears or voids forming in the surface, without the edges sagging or slumping, and without sloughing along the edge. Mixtures so selected will generally have slumps ranging from $1 / 2$ to $1-1 / 2$ in.

50. Unfortunately, there are no rules for selecting a mix. The only feasible way to select a mix appears to be one of trial and error. However, the considerable experience obtained in civil airfields can be used to good advantage. The starting point for a mix design should be a review of any previous slipform construction with local materials. If such information is not available, the logical starting point would be mixes used previously with form paving. From an initial mix, modifications can be made which will yield a mix that can be placed and which provides the desired strength and durability.

51. Certain material characteristics observed during the field study are summarized in Table 1 . The cement contents for the observed jobs ranged from 520 to $580 \mathrm{lb} / \mathrm{yd}^{3}$. Entrained air contents ranged from 4 to 6 percent, with durability probably being the critical requirement for entrained air. Maximum size coarse aggregate ranged from $1 / 2$ to $2-1 / 2$ in. with $1-1 / 2$ in. being the most common. Contractors tend to favor the use of smaller coarse aggregate. Fine aggregate on a percentage by weight of the total aggregate content ranged from 34 to 45 percent. The exact percentage needed will depend on the gradation of the fine aggregate as well as the coarse aggregate used, but tendency is to use higher fine aggregate content. As mentioned previously, contractors tried to maintain slumps of from $1 / 2$ to 1 in. for the airfield projects. On the one vehicular pavement, the contractor tried to maintain a slump of 1-3/4 in. This is compatible with thinner pavements which leads to easier control of edge slump. The practices observed on these jobs represent a rather wide range of conditions and may prove valuable in establishing a good mix. 


\section{PREPARATION OF UNDERLYING MATERIAL}

52. The preparation of the underlying material for slipform paving differs from that for form paving in that the fine grading must be done without aid of the forms. The most common procedure utilizes an automatically controlled fine grader which operates from a preset stringline and is able to accurately finish the surface. When the paver is to be controlled from the surface of the underlying material, the use of an automatically controlled fine grader is essential to meet surface smoothness requirements. When the paver is to be controlled from a preset stringline, accurate preparation of the underlying material is not so important to surface smoothness, but will be important in maintaining thickness control.

53. For slipform paver operation, it is necessary to prepare a path for the tracks of the machine. This is usually accomplished by preparing the underlying material several feet wider than the width of the paving lane. The path from which the paver operates should be stable and able to withstand the load imposed by the paver. The surface should also conform as closely as possible to the stringline from which the paver is controlled. The automatic controls will theoretically eliminate the influences of any irregularities in the track path, but the electro-hydraulic-mechanical system has a limited time-space response capability; thus, accuracy of the finished pavement surface will increase as the required response of the control system is decreased. That is, the more accurate the path along which the paver tracks move, the more accurate will be the finished pavement surface.

\section{GRADE AND ALIGNMENT CONTROL}

54. On all modern slipform paving equipment, both horizontal alignment of the machine and vertical alignment of the forming mechanism are automatically controlled by electro-hydraulicmechanical systems. The reference surface or line is mechanically sensed and any deviation from the preset relationship between the reference and the forming mechanisms is converted into an electrical signal. The electrical signal activates the control system which, in turn, activates a hydraulic system that adjusts the position of the forming mechanism in relationship to the vertical position of the tracks for vertical alignment or adjusts the direction of travel of the tracks for horizontal alignment. Figure 6 is a schematic illustrating a typical control system for controlling vertical grade. Systems for horizontal alignment are similar except that the signal from the control system activates a mechanical or hydraulic system which varies the direction of travel of the tracks.

55. As with any mechanical or hydraulic system, the control system has certain limitations. The sensing mechanism and hydraulic or mechanical loading mechanism are not able to instantaneously produce input signals or respond to the output signals of the control system. There are time lags and spatial limitations associated with the input of the mechanical signal from the sensing mechanism to the control system and with the response of the loading mechanism to the electrical signal from the control system. These response limitations have a beneficial effect in that they dampen the effects of abrupt changes in the reference or erroneous inputs to the sensing mechanism. However, they also attenuate the response of the loading mechanism to desired inputs from the sensing system. As with any electrical or hydraulic system, there are also inherent problems of stability and false signals.

56. Vertical alignment may be referenced to a preset stringline or from a previously prepared surface such as the underlying material or previously constructed pavement. Photo 16 illustrates a type of sensor used with stringline. Photo 17 illustrates a typical sensor used when vertical alignment is referenced to a previously prepared surface. 


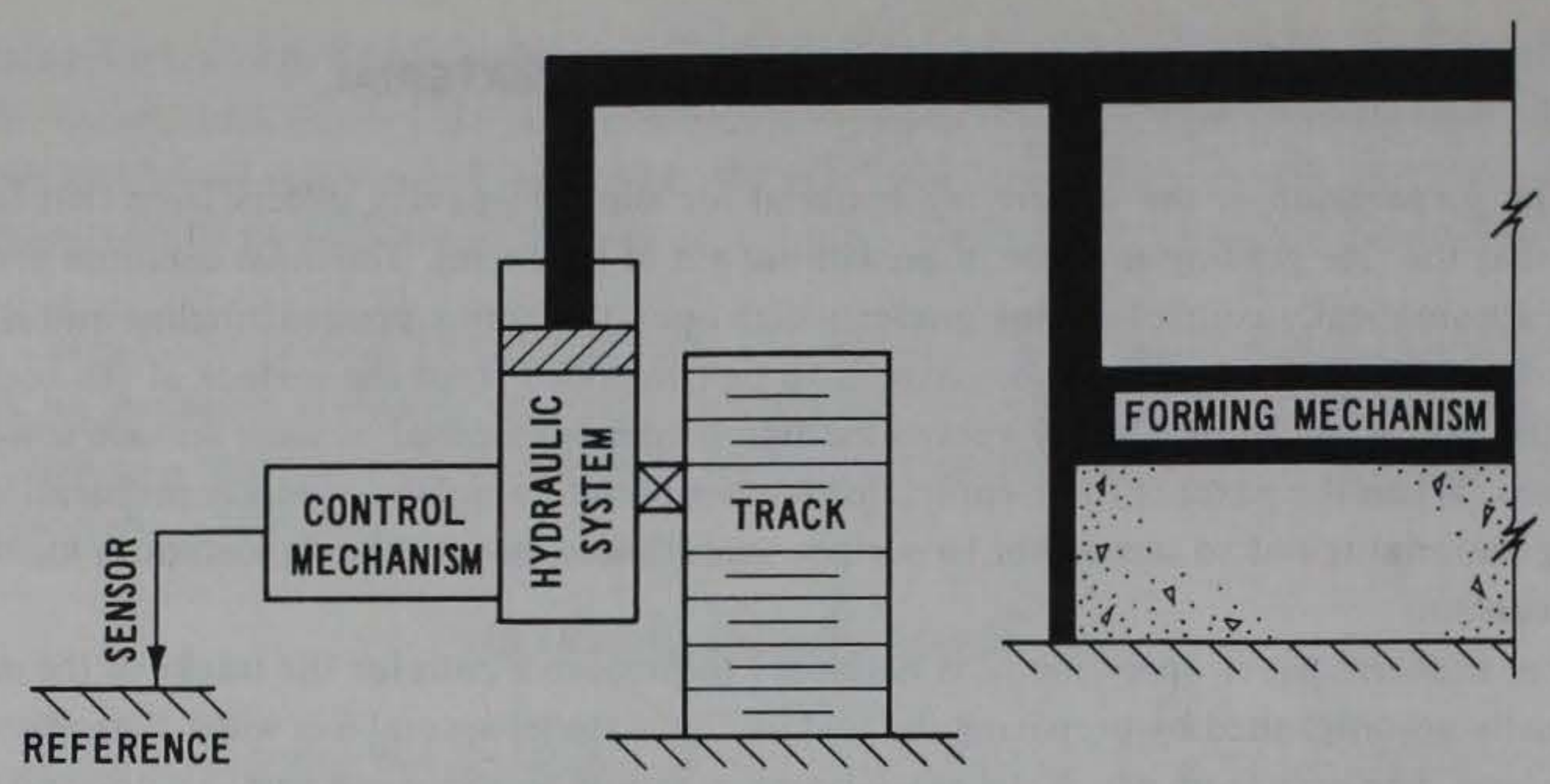

COMPONENTS OF CONTROL SYSTEM

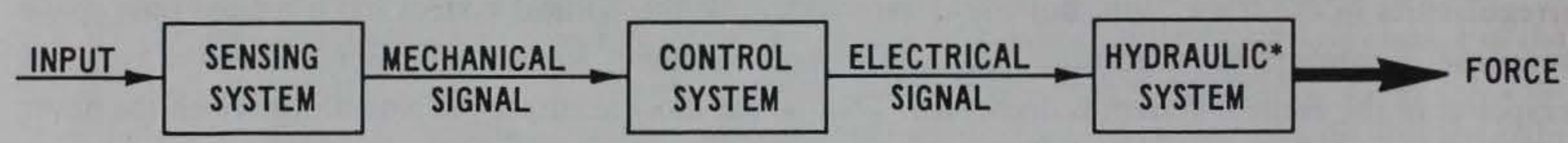

* maY be a mechanical SYStem

\section{FLOW OF SIGNAL THROUGH CONTROL SYSTEM}

Figure 6. Schematic of typical control system

57. Horizontal alignment may be referenced to a preset stringline (Photo 16) or to the edge of previously constructed slabs.

58. In addition to the automatic control systems, the horizontal alignment and vertical grade can also be controlled manually. Another method which can be used for vertical grade control is referred to as "locking on grade." With this method, the relationship between the bottom of the tracks and the forming mechanisms are set and locked. When this is done, the path followed by the forming mechanisms will be parallel to the path followed by the tracks. This method is used when the underlying material is stable and has been graded accurately or when the tracks travel on previously placed slabs.

\section{PRODUCTION AND TRANSPORTATION OF CONCRETE}

59. As was discussed previously, the need for large quantities of uniform consistency low slump concrete with slipform paving has led to use of large capacity central batch and mix plants with large quick discharge haul units. On the nine jobs observed, central batch and mix plants were used on eight. On the ninth job, an automatic batch plant was used but mixing was accomplished in truck mixers. The plants ranged in size from 8- to 12-cu-yd capacity plants. Central batching and mixing facilities (Photo 4) can produce large quantities of uniform low slump concrete required to keep slipform paving trains moving at a uniform speed, even for thick airfield pavements.

60. Mixed concrete is transported in agitating or nonagitating trucks. When hauled in a nonagitating unit, the discharge should be completed 45 min after mixing. 9,10 Since the mixing facility will usually be located near the paving site for airfield pavements, nonagitating trucks are used more 
than agitating units. There are probably other reasons for using this type of unit, e.g. initial cost, multiple use, and speed of discharge. Of the nine projects observed, nonagitating end dumps were used on five, nonagitating side dumps on two, nonagitating end dumps and side dumps on one, and truck mixers on one. Photo 6 shows a side dump in operation; Photos 7 and 8 show end dumps in operation. The selection of a particular type haul unit will be influenced by the system used for distributing the concrete.

\section{DISTRIBUTION OF CONCRETE}

61. The system used for distributing the concrete across the paving lane in front of the paver will be dictated by project conditions such as use of reinforcing steel, use of dowels or other hardware in transverse joints, and whether concrete will be hauled over the prepared underlying material. The use of central mix concrete has virtually eliminated the use of paving mixers which employed a bucket on a boom for distributing concrete. Presently, the two most common procedures involve dumping the concrete directly onto the underlying material or using a mechanical spreader.

62. When the concrete is dumped directly onto the underlying material, spreading or distribution across the paving lane is accomplished by an auger mounted on the paver. This procedure is used when the haul trucks are permitted to travel on the prepared underlying material and when the truck traffic will not interfere with placement of reinforcement or other hardware in the pavement. End-dump trucks are the most commonly used for this distribution procedure.

63. When job conditions prohibit dumping concrete directly onto the underlying material, a spreader must distribute the concrete across the paving lane. Several different types of spreaders are currently in use. Photos 7-9 illustrate several available types. There are two basic types of spreaders: The type shown in Photos 7 and 8 employs a moving belt or a belt and auger combination, and is referred to as a belt spreader; the second employs a moving compartment or box, and is referred to as a box spreader (Photo 9). Either type of spreader satisfactorily transports concrete from outside the paving lane to the paving lane. The haul unit used will depend on the type of spreader used. End-dump trucks are usually used with belt spreaders and side-dump trucks with box spreaders.

64. On two of the jobs observed, concrete was deposited directly onto the underlying material from end-dump trucks and on one job from truck mixers. On two other projects where the pavement was constructed in two lifts, concrete for the first lift was deposited on the underlying material from enddump trucks and concrete for the second lift was distributed with belt spreaders. On another two projects, belt spreaders and end-dump trucks were used; on two more projects, box spreaders and sidedump trucks were used.

\section{PLACEMENT OF REINFORCING STEEL}

65. Reinforcing steel (wire mesh or deformed bars) is placed by four methods: (a) presetting on chairs, (b) placing between lifts of concrete, (c) depressing to desired elevation through unconsolidated concrete, and (d) holding the steel in desired position while concrete is placed.

66. Photo 18 shows transverse and longitudinal reinforcing bars and dowel assemblies preset on chairs and ready for concrete placement. This procedure is usually used only for thin pavements (defined by CE specifications, Reference 8 , as 12 in. or less in thickness). It may be difficult to place concrete through the reinforcement to the bottom of the slab, especially when large quantities of steel are used, and to properly consolidate the concrete in the bottom of the slab. 
67. Photo 19 illustrates the two-lift method of construction. With this procedure, the first lift of concrete is placed and the reinforcing steel, prefabricated reinforcing bar mats or sheets of wire fabric, is placed on top of the first lift. The second lift of concrete is then placed on the first lift. Photo 19 shows the first lift and the steel in place and the spreader and paver placing the second lift.

68. Photo 20 shows wire mesh being depressed into a layer of preplaced and unconsolidated concrete. The mechanism for depressing the mesh is a series of curved shoes which oscillate vertically to depress the steel to the desired elevation. The mesh depressor is mounted on the front of the paver which consolidates and finishes the concrete.

69. Photo 21 shows bar mats being lifted by a mechanism attached to the front of the spreader and held in position while concrete is placed. The spreader is followed by a paver which consolidates and finishes the pavement. This procedure is commonly used for continuous reinforcement.

70. Reinforcing steel was used on five of the nine projects observed. On one job, wire mesh was depressed; on two jobs, wire mesh was placed between lifts of concrete; on one project, reinforcing bar mats were placed between two lifts of concrete; and on one project, continuous reinforcement was lifted and held in position while concrete was placed.

\section{FORMATION OF KEYED OR KEYED AND TIED LONGITUDINAL JOINTS}

71. Keyed or keyed and tied longitudinal construction joints may be constructed by forming the key or the keyway. Both procedures have produced satisfactory results and problems. These problems are (a) sagging and sloughing of the key or upper lip of the keyway and (b) voids due to inadequate compaction of the concrete around the forming mechanism. The sagging and sloughing can be reduced by providing uniform concrete; the voids can be reduced by providing increased vibration near the edge and by keeping the maximum size aggregate less than one-half the smallest vertical dimension of the key or keyway lip. The use of metal keyway liners appears to add stability to the edge and reduces sagging of the upper keyway lip. Photo 22 illustrates good and poor key construction; Photo 23 illustrates good and poor keyway construction. The key in Photo $22 \mathrm{~b}$ has completely sloughed off, and the upper lip of the keyway in Photo $23 \mathrm{~b}$ has sagged and some sloughing has occurred.

72. Based on the field observations, it appears that keyed joints, when untied, are usually constructed by slipforming the key. There are exceptions and keyways, with and without metal liners, have been slipformed. However, the metal liners appear to work best when used with bent tie bars. One contractor inserted bent tie bars about every $10 \mathrm{ft}$ for the sole purpose of holding the liner in place, even though tie bars were not required in the particular area being paved.

73. On four jobs, keyed and tied joints were constructed with metal keyway liners and bent tie bars. On one job, keyed and tied joints were constructed by slipforming the key and driving tie bars into the consolidated concrete. On one job, keyed and tied joints were constructed initially by slipforming the keyway with a metal liner and driving the tie bars into the consolidated concrete through a slot in the side forms. However, this procedure was abandoned and the tie bars were grouted into holes drilled in the hardened concrete.

74. On four jobs, untied keyed joints were constructed by slipforming the key. On two jobs, untied joints were constructed by slipforming the keyway both with and without metal liners. 


\section{INSTALLATION OF DOWELS}

75. The installation of dowels in transverse contraction joints presents no unique problems. The dowels are mounted on a frame (see Photo 18) and attached to the underlying material. The dowels will be positioned near slab middepth so that the forming mechanism and vibrators can pass over the dowel assembly. The three most important factors to be considered when installing dowels in transverse joints are: (a) the dowels must be aligned properly; (b) the dowel assembly must be sufficiently rigid to prevent movement of the dowels when concrete is placed; and (c) the frame must be securely staked to the underlying material to prevent movement when the concrete is placed.

76. Dowels in transverse construction joints or transverse expansion joints present no unsurmountable problems with a slipform paver. The three most important factors to be considered are those enumerated for transverse contraction joints. The difference is that dowels are attached to the filler material or the header. The paver is brought as close to the header as possible before internal vibrators are lifted. When approaching a header sufficient concrete should be maintained in front of the paver to form a roll of concrete which is carried over the header, thus ensuring that the excess grout or mortar accumulating in front of the paver is not deposited adjacent to the header. Hand vibration is provided near the header to ensure adequate consolidation around the dowels.

77. Dowels in longitudinal construction joints have been installed successfully only by drilling holes in the hardened concrete and grouting the dowels in place with an epoxy grout. A number of other methods have been tried, such as inserting the dowels through slots in the side forms or driving them into the consolidated concrete. All of these methods failed because of one or more of the following reasons: (a) poor alignment, (b) disturbance of the edge, and (c) rate of installation insufficient to keep pace with paver.

78. On two jobs, dowels were installed in a portion of the longitudinal joints. On both jobs, the dowels were installed in holes drilled in the hardened concrete. Based solely on a visual examination, the alignment appeared to be adequate. It will be some time before the pavement receives enough traffic so that the structural adequacy of the joint can be evaluated, but there is no apparent reason that they will not perform adequately.

\section{MANUAL FINISHING AND SURFACE AND EDGE DEFICIENCY CORRECTION}

79. Manual finishing should be kept to a minimum. A characteristic of the slipform method is the machines are capable of forming and finishing the pavement in one pass. There will always be small areas which occasionally need touching up, but if these occur regularly, the mix or the machine should be adjusted.

80. Overworking of the surface can create a surface which is not durable. Overfinishing can remove the air from the concrete near the surface and produce a layer of mortar with a high water content. Overworking the surface is probably more pronounced with slipform pavers than with form pavers since the conditioning of the concrete by the slipform paver must be very vigorous for the surface to be formed in one pass of the forming mechanism without excessive tearing. This means that the mortar content near the surface is probably already fairly high, and any additional manipulation will only increase the probability of excessive mortar on the surface.

81. The same principles that apply to manual finishing apply to surface and edge correction, i.e., it should be kept to a minimum. If deficiencies occur regularly, adjustments should be made to the 
concrete mix or to the paver. Self-propelled tube floats (Photo 10) may be used to correct minor surface deficiencies and to locate high and low spots in the pavement surface. The most common problem with tube floats is that they are overused, with the results equivalent to excessive manual finishing.

82. The area of the surface that usually receives the most attention is the portion along the edges of slipformed lanes. The free standing edges all tend to slump or sag to varying degrees; several methods have been tried to eliminate the influence of edge slump. One involves increasing the thickness along the edge and tilting the top of the forms inward so that after the slumping has occurred the desired flat surface and square corner will be obtained. Another way, probably the least desirable, consists of working the surface and building up the edge with the resulting mortar. On one job, concrete (pea gravel aggregate) was mixed in small quantities and manually placed along the edge to reduce the effects of the edge slump and to produce a square edge. The new concrete was worked into the surface apparently to get good bond; the appearance of the edge produced was satisfactory. However, there are several unanswered questions concerning this procedure. First, is the durability of the surface along the edge affected; second, are the benefits of a square edge worth the considerable cost required to produce it?

83. When edges slump excessively in a localized area or when localized sloughing of keys or keyway lips occurs, it is common practice to provide lateral support (Photo 24) and to repair the edge manually. Another method repairs keys and keyways using epoxy grout after the concrete has hardened. Neither method is recommended for widespread use and, if edge stability problems persist, adjustments should be made to the mix or to the paver. 


\section{PART VI: ANALYSIS OF SMOOTHNESS MEASUREMENTS}

84. Smoothness measurements from all the projects observed are summarized in Table 2. The significance of the various groupings are previously described.

\section{TRANSVERSE MEASUREMENTS}

85. The transverse measurements will be considered first. The measurements showed that the free edges do slump or sag. The area affected by the edge slump appears to be a strip up to $4 \mathrm{ft}$ wide along the edges of the paving lane. The distance affected by edge slump appears to be proportional to the slab thickness and magnitude of edge slump; however, the measurements failed to show this conclusively. Typical measured shapes of several as-placed edges are shown in Figure 7. In these figures, the deviation decreases as the distance from the edge decreases. When adjustments are made or the edges manually manipulated to remove the effects of the edge slump, the shape may be altered.
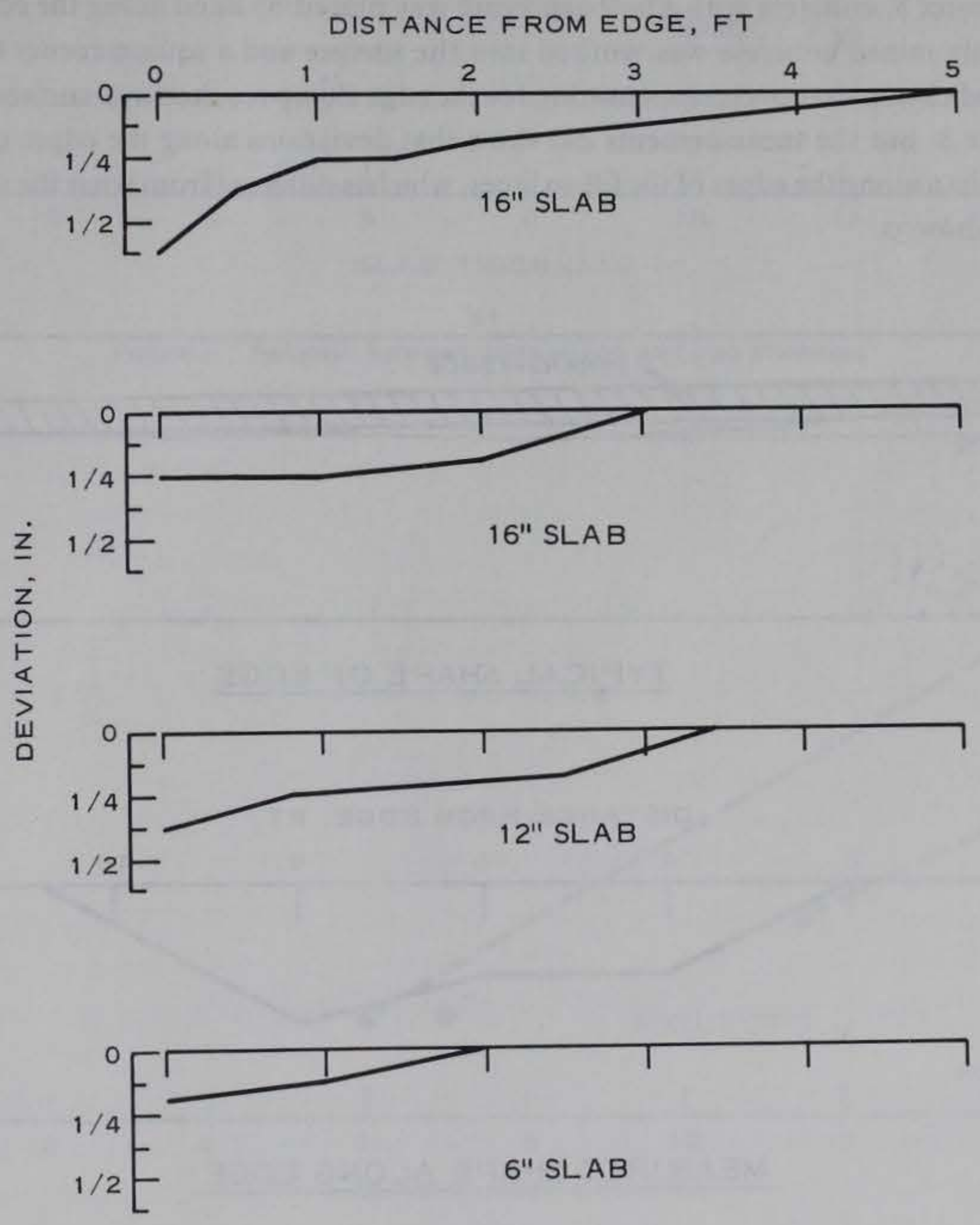

Figure 7. Typical measured shape of free edges 
86. The measurements show that a larger percentage of the measurements along the edge exceed $1 / 4$ in. than do the measurements in the slab interior (Table 2). This is also illustrated by the differences in the average deviation between the slab edge and interior, and by the difference between the deviation along the edge of a slipformed lane and the deviation along the edge of a fill-in lane. The measurements show, in general, that the average deviation is greater along the edge than in the interior, and that the deviations along the edge of the slipformed lanes are larger than those along the edge of fill-in lanes; however, there were several notable exceptions. The measurements at Project 3 showed less deviation along the slab edge than in the interior, as indicated by the percentage of measurements larger than $1 / 4$ in., and by the average measurements. Another exception is Project 8 where the fill-in lane showed a larger percentage of the edge measurements exceeding $1 / 4$ in. and a larger average deviation than did the slipform lanes. This was caused by the manual manipulation of the edges to reduce the effects of edge slump.

87. On Project 3 , the surface was worked extensively, producing large amounts of grout which were used along the edge to build up the edge and eliminate the effects of edge slump. This resulted in a square corner along the edge, but at times overbuilding of the edge created a surface shaped as shown in Figure 8.

88. On Project 8 , concrete with small aggregate was placed by hand along the edge of slipformed lanes. The freshly mixed concrete was worked into the surface and a square corner formed by hand. There was no indication that overcompensating for the edge slump resulted in a surface shaped like that shown in Figure 8, but the measurements did show that deviations along the edges of the slipformed lanes were less than along the edges of the fill-in lanes, which is different from what the measurements on the other jobs showed.

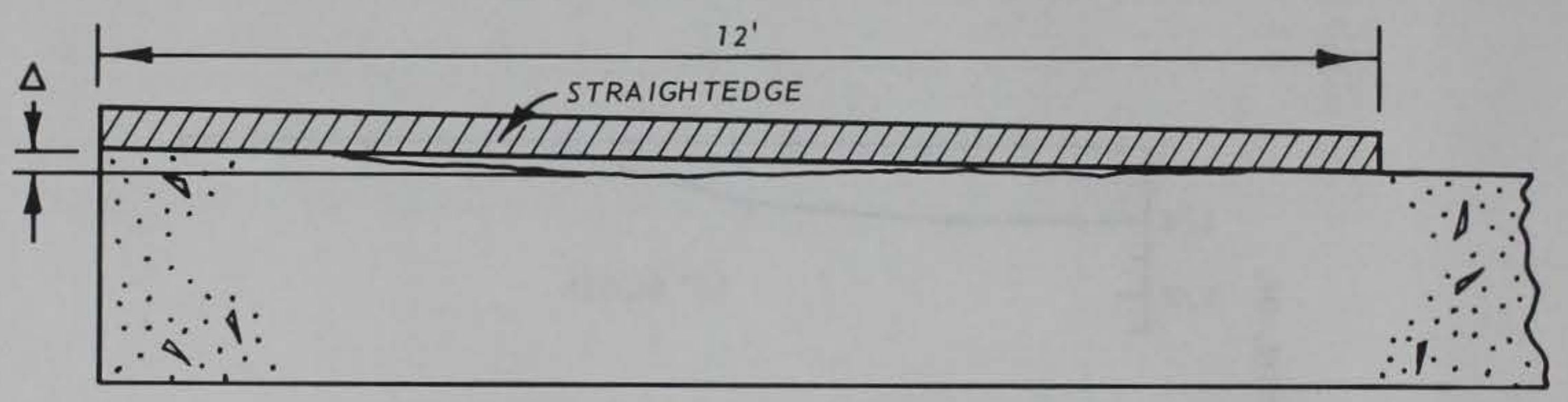

TYPICAL SHAPE OF EDGE

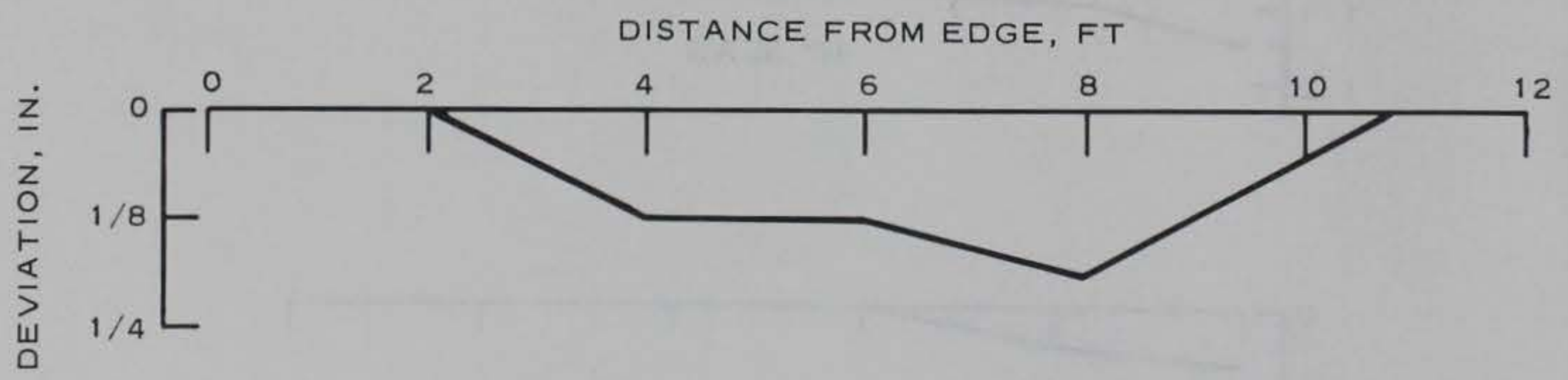

MEASURED SHAPE ALONG EDGE

Figure 8. Edge showing influence of overcompensating for edge slump 
89. The magnitude of the edge slump will be proportional to the slab thickness. Figures 9 and 10 show average edge deviation and percent of measured deviation exeeding $1 / 4$ in. plotted as a function of slab thickness. The two points on each curve which do not follow this pattern are measurements on Projects 3 and 8 , where hand manipulation reduced the effect of edge slump.

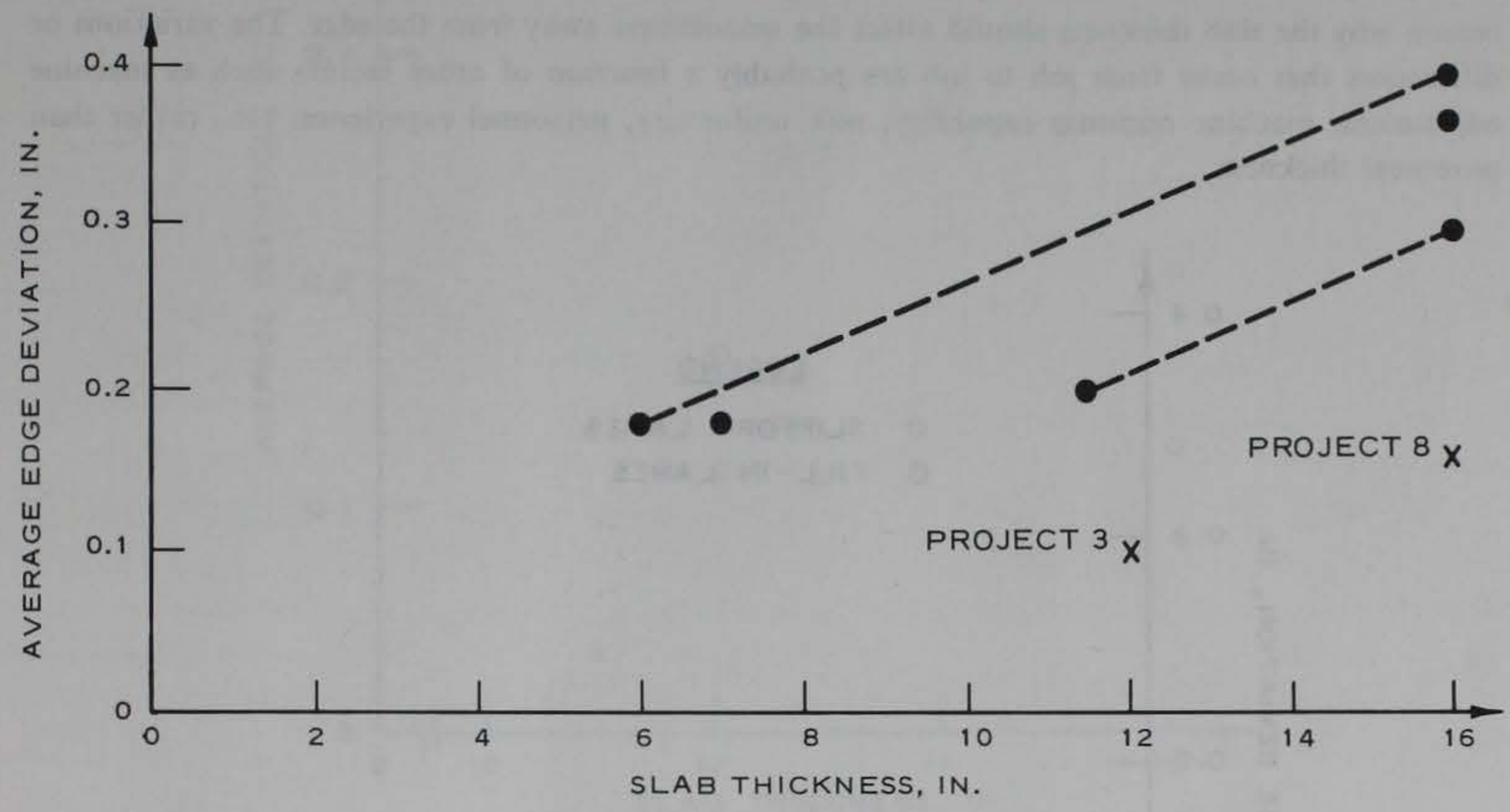

Figure 9. Relation between edge slump and slab thickness

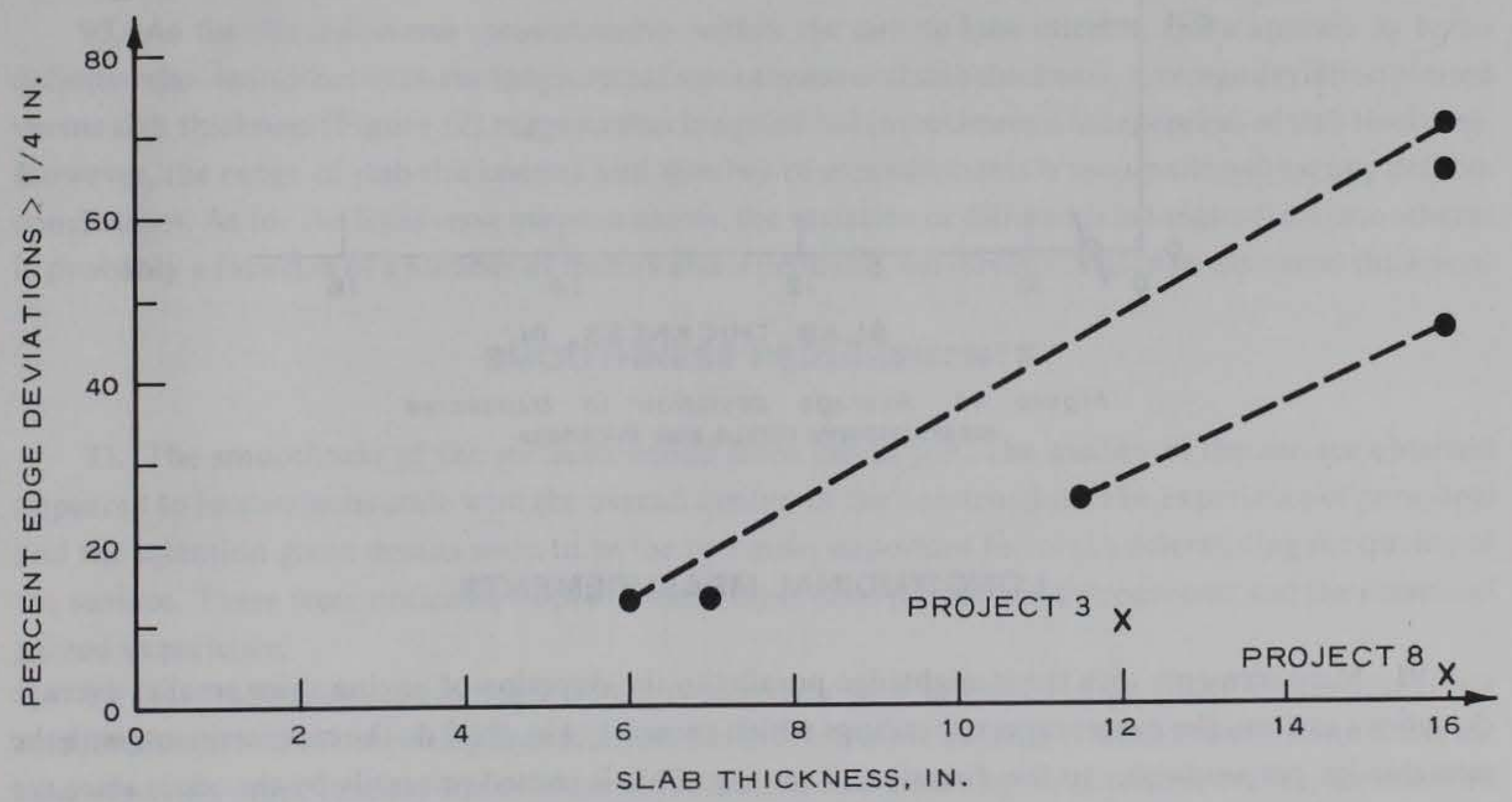

Figure 10. Relation between percentage of edge deviations exceeding $1 / 4 \mathrm{in}$. and slab thickness 
90. From the measurements made, no definite correlation was apparent between the transverse measurements made within the slab interior and slab thickness. The range of thickness was limited (11.5 to 16 in.) but it appears that the average deviation in the interior of the slab may be independent of slab thickness (see Figure 11). The two points plotted for the fill-in lanes tend to substantiate this contention, but more points would be necessary to draw any definite conclusions. However, there is no physical reason why the slab thickness should affect the smoothness away from the edge. The variations or differences that occur from job to job are probably a function of other factors such as machine adjustment, machine response capability, mix uniformity, personnel experience, etc., rather than pavement thickness.

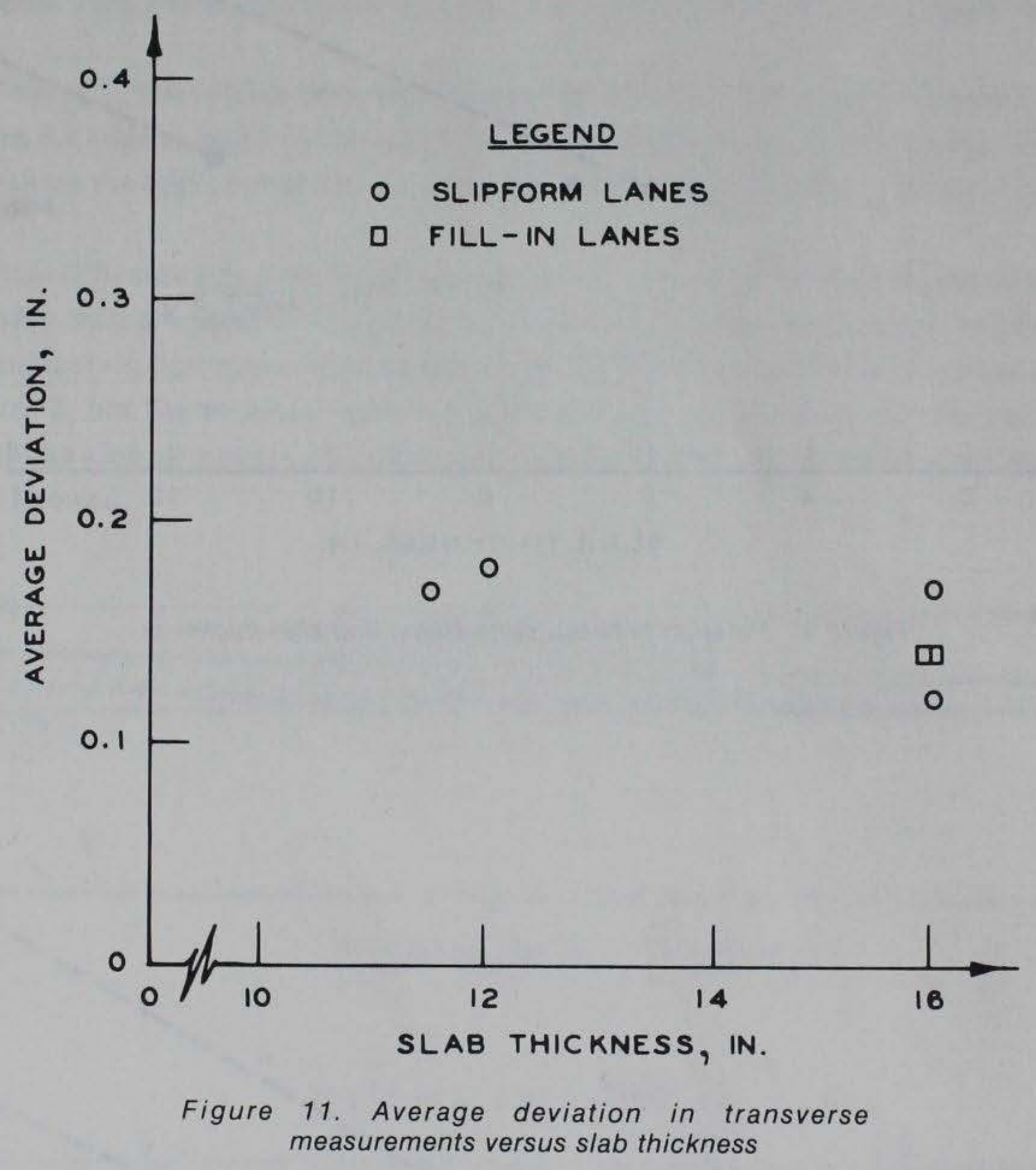

\section{LONGITUDINAL MEASUREMENTS}

91. Measurements with the straightedge parallel to the direction of paving show smaller average deviations and smaller percentages of readings which exceed $1 / 4$ in. than do the measurements with the straightedge perpendicular to the direction of paving. This is caused primarily by the edges since the average deviations and percentages for the transverse measurements in the lane interior are similar to those for the longitudinal measurements. 


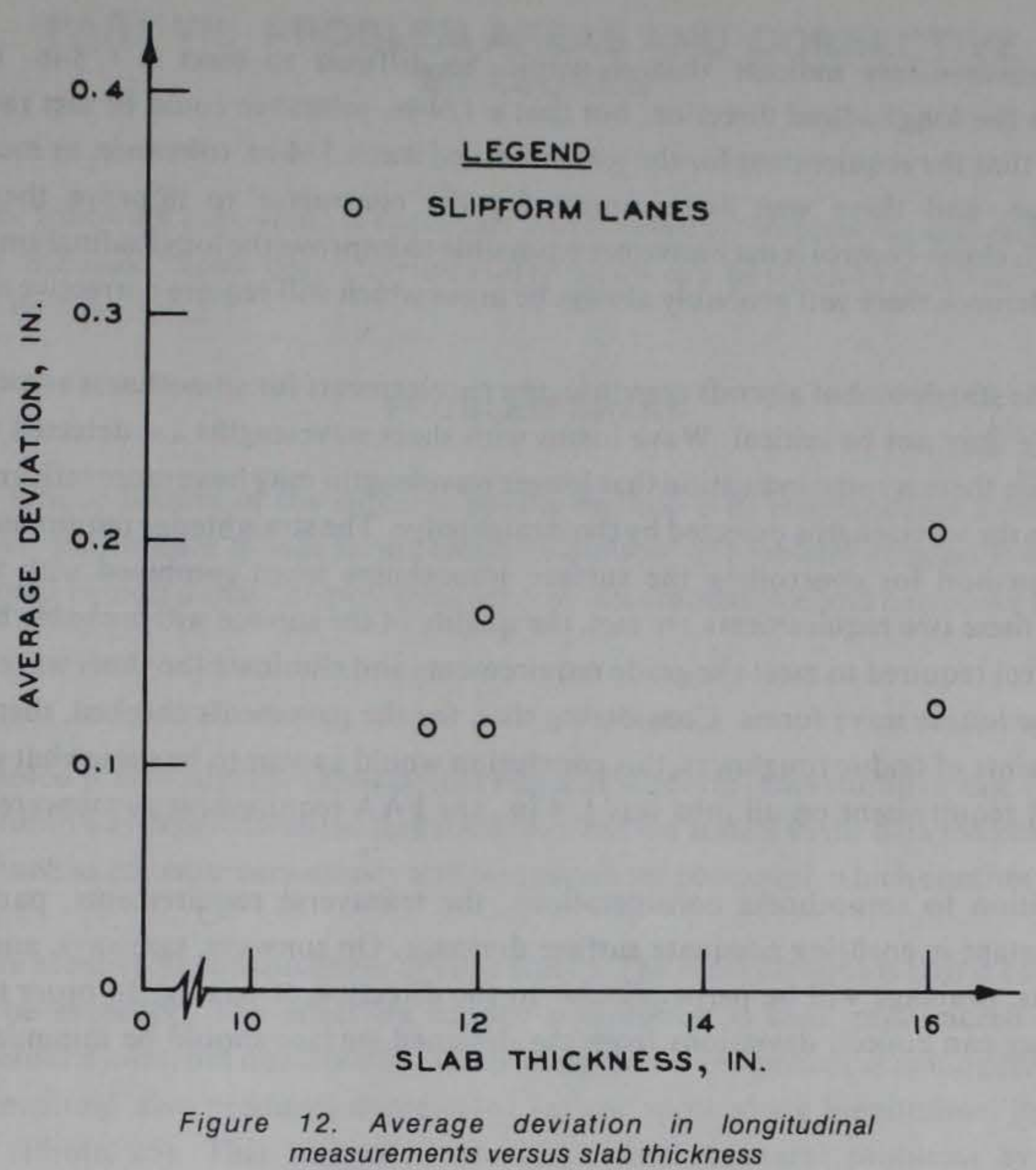

92. As for the transverse measurements within the paving lane interior, there appears to be no definite relationship between the longitudinal smoothness and slab thickness. Average deviation plotted versus slab thickness (Figure 12) suggests that longitudinal smoothness is independent of slab thickness. However, the range of slab thicknesses and number of measurements is too small to draw any definite conclusions. As for the transverse measurements, the variation or difference in longitudinal smoothness is probably a function of a number of factors and is probably not directly related to pavement thickness.

\section{SMOOTHNESS REQUIREMENTS}

93. The smoothness of the surfaces varied from job to job. The quality of the surface obtained appeared to be commensurate with the overall quality of the construction. The experience of personnel and the attention given details seem to be the two most important factors in determining the quality of the surface. There were noticable improvements on several jobs as work progressed and the personnel gained experience.

94. The measurements indicate that it is relatively easy to meet $1 / 4-i n$. tolerance for transverse measurements within the paving lane interior, but that it is more difficult to meet this tolerance along the lane edges. In order to meet smoothness requirements along the edge of slipformed lanes, the machine and concrete mixture must be properly adjusted and the machine must move forward at a uniform rate without frequent stops. 
95. The measurements indicate that it would be difficult to meet a $1 / 8$-in. tolerance for measurements in the longitudinal direction, but that a $1 / 4$-in. tolerance could be met rather easily. It should be noted that the requirement for the jobs observed was a 1/4-in. tolerance, as measured with a 16- $\mathrm{ft}$ straightedge, and there was no incentive for the contractor to improve the longitudinal smoothness. With closer control it may have been possible to improve the longitudinal smoothness, but with a 1/8-in. tolerance there will probably always be areas which will require corrective measures such as grinding.

96. From the standpoint of aircraft response, the requirements for smoothness as measured with a 12-ft straightedge may not be critical. Wave forms with short wavelengths are detected with the $12-\mathrm{ft}$ straightedge, while there is some indication that longer wavelengths may have more influence on aircraft response than do the wavelengths detected by the straightedge. The straightedge requirements provide a relatively easy method for controlling the surface smoothness when combined with vertical grade requirements. If these two requirements are met, the quality of the surface will probably be satisfactory because the control required to meet the grade requirements and eliminate the short wave forms should also eliminate the longer wave forms. Considering that, for the pavements checked, there has been no apparent complaints of undue roughness, this conclusion would appear to be somewhat substantiated. The longitudinal requirement on all jobs was $1 / 4$ in., the FAA requirement as measured with a $16-\mathrm{ft}$ straightedge.

97. In addition to smoothness considerations, the transverse requirements, particularly edge slump, are important in ensuring adequate surface drainage. On runways, taxiways, and, at times, on apron pavements, drainage will be perpendicular to the direction of paving. In order to prevent low areas where water can collect, deviations from the designed surface should be minimized. 


\section{PART VII: PROBLEM AREAS AND CORRECTIVE MEASURES}

98. In the following part, some of the causes and effects of problem areas associated with slipform paving will be discussed. Some corrective measures which can be taken to minimize or eliminate the problems will be considered.

\section{PROBLEM AREAS}

99. The unique feature of the slipform paving method is its independence from stationary side forms. However, the absence of side forms creates a number of problems associated with the slipform method. It should be noted that the problems are not insurmountable and corrective measures will be considered.

\section{Edge Slump}

100. As noted previously, the unsupported edges of slipform lanes slump or sag. It was also noted that the edge slump was proportional to slab thickness, but the scatter in the data indicated that there are other factors, such as concrete consistency and inexperienced personnel, which contribute equally to the edge slump.

101. There are several consequences of edge slump. The most obvious is that it causes smoothness tolerances to be exceeded. The effect on surface smoothness is most pronounced when measured transversely across a joint, but nonuniform slump along the lane edge can cause longitudinal roughness.

102. Edge slump also produces depressions or low spots along longitudinal joints which may collect water (Photo 25). This trapped water can create structural problems by infiltrating the underlying material or cause operational problems, such as reducing skid resistance.

103. Edge slump causes construction problems during placement of fill-in lanes. If the corner of the slipform lane edge is not square and if the thickness of the slab along the edge is not as designed, it will be difficult to form the surface of the fill-in lane along the joint. This results in a poorly formed joint which will not meet smoothness requirements and which may be difficult to seal, especially if preformed compression seals are to be used.

104. The effects of edge slump can be minimized by manual finishing, a procedure not recommended because excessive manual finishing may cause other problems. If fresh concrete is placed along the edge, the cost of the pavement will increase in proportion to the cost of the extra personnel and equipment.

\section{Surface Smoothness, Vertical Grade, and Slab Thickness Control}

105. The classification of these as problem areas may not be justified. Apparently, no definite conclusions, substantiated by comprehensive data, have ever been drawn concerning the comparison of fixed-form or slipform construction. The classification "problem area" arises not from the inability to control smoothness, grade, and thickness with the slipform method, but because of the complexity of the equipment and procedures needed for control of smoothness, grade, and thickness without the aid of fixed forms.

106. With fixed forms, final grading of the surface of the underlying material, placement of the 
concrete, and forming the pavement surface are referenced to the top of the forms. The equipment and procedures used for grading the underlying material and forming the pavement surface are rather simple. Assuming that the forms were accurately and firmly set, the control of smoothness, grade, and thickness involves simply keeping the cutting edge of the subgrade planer and the forming mechanism of the paver in the proper shape and the wheels of the machine in contact with the top of the forms.

107. With slipform pavers, the equipment and procedures are more complex. When a stringline is used to control the automatically controlled fine grader or slipform paver, a sensor follows the stringline and an electro-hydraulic system controls the position of the cutting edge or the forming mechanism relationship to the position of the stringline. This is somewhat more complicated than keeping the wheels of the subgrade planer or paver in contact with the top of the forms. There are more opportunities for equipment malfunction; there is also the time lag factor in the response of the paver to the signal received from the sensor. These factors also apply when the surface of the underlying material is used as the reference for controlling the slipform paver. Thus far, it has been assumed that forms or stringline could be erected to design requirements. There are limitations to the accuracy which can be achieved using forms or stringlines, but the accuracy for either is probably comparable. The maintenance of the top of the forms, the stringline, and the surface of the underlying material after construction are also factors in determining the control of smoothness, grade, and thickness.

108. When stringline is used, it should be constantly monitored to ensure that the inevitable contact with workmen and equipment does not displace it. With all the activity around a paver, it is impossible to isolate the stringline or to erect the supports that are completely fixed.

109. The final grading of the underlying material is referenced to the top of the forms when fixed forms are used. When slipform pavers are used, the final grading may be referenced to a stringline or controlled by some other means. The grading of the underlying material affects the grade, smoothness, and thickness control if the operation of the paver is controlled from the surface. If a stringline is used to control the paver, the grading of the underlying material will affect the thickness control, since the position of the forming mechanism is controlled only by the stringline and is independent of the surface of the underlying material.

110. When the underlying material is used to control the paver, by either sensing the surface or by locking on grade (fixing the distance beteen the forming mechanism and the bottom of the tracks), the pavement surface will reflect the surface of the underlying material. Any depressions or high areas that develop in the path of the sensors (skis or wheels) or the tracks will cause high or low spots on the surface and inadequate or excessive pavement thickness.

111. The maintenance of stringlines and the surface of the underlying material would apparently require more care than the maintenance of fixed forms. However, with fixed forms, the paver rides on the forms and may cause their settlement if the underlying material is not firm enough to sustain the load. With slipform pavers, a similiar problem exists when the paver is locked on grade and the track path deforms under load. This can result in a rough surface and deficient thickness since the distance between the bottom of the tracks and the forming mechanism is set at a fixed value.

112. From the preceding discussion, it is apparent that the basic requirements for controlling pavement smoothness, grade, and thickness are identical for fixed form and slipform methods. These are to provide an accurate and stable reference system and an unyielding foundation from which to operate the paver. Fixed forms provide both the reference and foundation from which the paver operates. For slipform operations, the reference and operating platform may be separate and must be linked with a control system. For this reason, more care and skill is required for adequate control of pavement smoothness, thickness, and grade without the aid of fixed forms. 


\section{Load Transfer Devices in \\ Longitudinal Construction Joints}

113. This is another problem area brought about by movement of the side forms with the paver and the independence of the edges from lateral support. Problems exist with the formation of vertical faces, but the problems are compounded by the formation of keys or keyways and the installation of dowels and tie bars.

114. There are two problems associated with the formation of keys and keyways. The first occurs during the formation process. The concrete must flow to conform to the desired shape of the key or keyway. If sufficient vibration is not applied or if the size of the aggregate exceeds about one-half the size of the smallest vertical dimension of the key or keyway, voids or honeycombs may result.

115. The second problem occurs after the side forms pass and leave the edge without lateral support. For keys and the upper lips of keyways, there is also a horizontal face without vertical support. This can accentuate the problem of edge slump and sloughing.

116. The formation of keyways with permanent metal liners appears to minimize both problems. The formation of a keyway may be defined as a process whereby the form attached to the side form forces concrete away from the edge to form the keyway as opposed to the process of forcing concrete into the form attached to the side form to form the key. The formation of the keyway does not appear to be as sensitive to aggregate size or level of vibration as does the formation of the key. The use of a metal liner also provides vertical support to the upper lip of the keyway after the side forms pass.

117. Tie bars should be in place in the concrete while it is being consolidated to ensure adequate bond since the installation of tie bars after the concrete has been consolidated may result in insufficient bond and disturbance of the edge. However, unless the tie bars are bent or a slot provided in the side forms to permit the tie bars to pass by or through the forms, they must be inserted after the concrete has been consolidated. The most successful method utilized thus far has been to bend the tie bars and insert them through a metal keyway liner. However, with this method, when high strength steel is specified, the bars cannot be bent without seriously affecting their strength.

118. The problems associated with the installation of dowels is aggravated by the fact that dowels cannot be bent. However, since bond of the dowels is not critical, the solution would appear to be to install them behind the paver in the consolidated concrete. Unfortunately, dowel alignment is also critical and proper alignment control cannot be achieved by driving or pushing dowels into the consolidated concrete. As with tie bars, the installation of the dowels disturbs the edges and the surface near the edge. As mentioned previously, the only successful way to install dowels is to grout them into holes drilled into the hardened concrete.

\section{Construction Logistics}

119. The amount of concrete needed to keep a slipform paver moving at a uniform rate when placing thick airfield pavements can result in considerable congestion around the paver. No matter what type of haul equipment or what procedures are used for depositing the concrete in front of the paver, a schedule for placing the paving of the various lanes and haul routes must be formulated which will allow a continuous flow of concrete from the batch or mix facility to the paving site.

120. The method used for controlling the paver will affect the operation at the paving site. The use of stringline will restrict the flow of construction traffic around the paver. 


\section{CORRECTIVE MEASURES}

121. In this section, procedures which can correct or minimize some of the problems noted previously will be discussed.

\section{Proper Mix Selection}

122. Local materials and placement conditions vary. No standard mix design procedure is available, therefore the selection should be based on experience with local materials.

123. The basis for selecting a mix should be the quality of the pavement obtained with the mix. The mix should permit the surface to be finished without undue tearing. One pass of the machine should produce a dense sealed surface which requires only a minimum amount of hand finishing to correct localized unsatisfactory areas.

124. The selection of a good mix will improve the stability of the edges and surface smoothness. The mix influences the quality of keys or keyways. The maximum size coarse aggregate will affect the formation of keys; the maximum size coarse aggregate should be less than or equal to one-half the minimum vertical key dimension.

\section{Concrete With Uniform Consistency}

125. Once a mix is selected, it is important that uniformity be maintained. Adjustments can be made to the paver so that concrete with a fairly wide range of properties can be placed. Adjustments may be necessary in mix proportions to take care of such things as changes in placement conditions. However, once the adjustments are made, the operation of the paver should be as free from interruptions as possible. If the concrete consistency is not uniform, excessive edge slumping, nonuniform surface finish, and an uneven surface may result.

\section{Steady Movement of Paver}

126. Each time the paver stops and starts, the potential for creating a rough spot in the pavement surface or edge slump is increased. Even though the paver may be stopped, the power units will still be running, thereby inducing vibrations in the concrete. When the paver starts, the concrete may surge under the forming mechanisms creating a high spot or the vibration of the forming mechanism may have formed a low spot. The edges are also more susceptible to slumping and sloughing immediately after the paver starts.

127. In order to avoid or minimize these problems, the movement rate of the paver should be adjusted to match the delivery rate of concrete. Based on the field observations, this is practically impossible, but stopping and starting of the paver should be kept to a minimum.

\section{Accurate Preparation and Proper Main- tenance of Underlying Material or Stringline}

128. The surface of the pavement will be a reflection of the surface from which control of the paver was referenced, i.e., a stringline or the surface of the underlying material. This will require the underlying material or stringline to be prepared and maintained at the same tolerances as those required of the pavement surface.

129. The stability of the underlying material in the track path is important. If the track path deforms beneath the weight of the paver, the control system will have to be constantly making adjustments to keep the forming mechanism in the proper relationship to the reference line or surface. 
The control system has a limited response capability. Although the system can make the adjustments normally encountered, the accuracy of the control will increase as the number and magnitude of necessary adjustments are decreased.

130. When the paver is locked on grade, the material in the track path will have to be unyielding to meet smoothness, grade, and thickness requirements. This is necessary because the distance between the bottom of the tracks and the forming mechanism is fixed. If the track path deformed under the track, a low spot in the surface and an area deficient in thickness would result.

\section{Skill of Personnel}

131. The operation of slipform pavers and the accessory equipment in a paving train requires skill considerably greater than that required when operating fixed-form equipment. The skill of the paving crew is the one factor which, more than any other factor, affects the quality of the pavement constructed.

132. As mentioned earlier, the quality of the workmanship on a job usually improves as work progresses and the paving crews become more experienced. One of the jobs observed was a contractor's first experience with a slipform paver. A cursory examination of the pavement placed showed a vast improvement in the pavement quality as the work progressed. These observations were substantiated by the project engineers. A frequent comment was that problems were encountered initially but, after adjustments were made and after the crews determined what needed to be done, the quality improved significantly.

133. Equipment manufacturers recognize this problem and provide special schools for equipment operators and mechanics. The equipment manufacturers also provide trained personnel to aid the contractor in solving special problems. However, other key men in the paving crew, such as field supervisors, batch and mix plant operators, and coordinators between haul trucks and paver operators can significantly affect the quality of the pavement obtained. The only way a contractor can ensure he has the trained personnel needed is to maintain a nucleus of trained personnel and to use these personnel to train replacements. 


\section{PART VIII: CONCLUSIONS}

134. Slipform pavers can be used to construct runway, taxiway, and apron pavements which will be structurally and functionally adequate for aircraft operation. The use of slipform pavers will require a concentrated effort on the part of the contractor and the engineer to ensure that the design, field adjustments, and quality control procedures result in a pavement with the desired characteristics. Of particular importance are the requirements for a steady flow of concrete with uniform consistency to ensure a uniform rate of paver movement, and a comprehensive inspection program for evaluating the surface smoothness. The additional cost incurred because of increased engineering and inspection will be offset by the savings in both time and money achieved through the use of slipform pavers. 


\section{REFERENCES}

1. Gillis, L. R. and Spickelmire, L. S., "Slip-Form Paving-Construction Practices for 3-Lane-at-aTime Paving in California," Highway Research Record No. 98, Jan 1965, National Research Council - National Academy of Sciences, Washington, D. C.

2. "Slip-Form Paving in the United States," Technical Bulletin No. 263, 1967, American Road Builders Association, Washington, D. C.

3. Ray, G. K. and Halm, H. J., "Fifteen Years of Slip-Form Paving," Proceedings, American Concrete Institute, Vol 62, No. 1, 1965, pp 145-158.

4. Deshaye, B. and Fournier, R., "Construction of Reinforced Concrete Pavement by the Slip-Form Method," Proceedings, Canadian Good Roads Association, Sep 1967, pp 203-211.

5. Halm, H. J., "Concrete Paving_-Two Miles per Day," Technical Bulletin No. 5, 1969, American Concrete Paving Association, Oak Brook, Ill.

6. Ray, G. K., "Slip-Form Paving Yields Concrete Advantages," Airport Services Management, Jul 1971.

7. Federal Aviation Administration, Department of Transportation, "Advance CriteriaSpecification P-501, Portland Cement Concrete Pavement-Slip-Form Method-AC 150/53701A," Order 5370.4, May 1971, Washington, D. C.

8. Office, Chief of Engineers, Department of the Army, "Corps of Engineers Guide SpecificationMilitary Construction-Concrete Pavement for Roads and Airfields," CE-806.01, May 1964, Washington, D. C.

9. Departments of the Army and Air Force, "Standard Practice for Concrete Pavements," Technical Manual TM 5-822-7 and Air Force Manual AFM 88-6, Chapter 6, May 1964, Washington, D. C.

10. "Proposed Revision of ACI 617-58: Recommended Practice for Construction of Concrete Pavements and Concrete Bases," Journal, American Concrete Institute, Vol 70, No.8, Aug 1973, pp 545-570. 
Table 1

Material Characteristics

\begin{tabular}{|c|c|c|c|c|c|c|}
\hline $\begin{array}{c}\text { Project } \\
\text { No. } \\
\end{array}$ & $\begin{array}{c}\text { Design } \\
\text { Concrete } \\
\text { Slump } \\
\text { in. } \\
\end{array}$ & $\begin{array}{c}\text { Design } \\
\text { Entrained } \\
\text { Air, \% } \\
\end{array}$ & $\begin{array}{l}\text { Cement } \\
\text { Content } \\
\text { lb } / \mathbf{y d}^{3} \\
\end{array}$ & $\begin{array}{c}\text { Type Coarse } \\
\text { Aggregate }\end{array}$ & $\begin{array}{c}\text { Maximum } \\
\text { Size } \\
\text { Coarse } \\
\text { Aggregate } \\
\text { in. } \\
\end{array}$ & $\begin{array}{c}\text { Percentage } \\
\text { Coarse } \\
\text { Aggregate } \\
\end{array}$ \\
\hline 1 & 1 & 6 & 580 & Crushed limestone & $1 / 2$ & 55 \\
\hline 2 & $1-3 / 4$ & 6 & 564 & Crushed limestone & $1-1 / 2$ & -- \\
\hline 3 & 1 & 6 & 564 & Crushed limestone & $2-1 / 2$ & - \\
\hline 4 & $3 / 4$ & 6 & 540 & Crushed syenite & $1-1 / 2$ & -- \\
\hline 5 & $3 / 4$ & - & 520 & Crushed limestone & $1-1 / 2$ & - \\
\hline 6 & 1 & 4 & 520 & Natural gravel & $1-1 / 4$ & 65 \\
\hline 7 & -- & - & -- & Natural gravel & $1-1 / 2$ & - \\
\hline 8 & $1 / 2$ & 4 & 540 & Crushed limestone & $1-1 / 2$ & 66 \\
\hline 9 & $3 / 4$ & -- & 504 & -- & $1-1 / 2$ & - \\
\hline
\end{tabular}


Table 2

Summary of Smoothness Measurements

\begin{tabular}{|c|c|c|c|c|c|c|c|c|c|c|}
\hline \multirow[b]{3}{*}{$\begin{array}{l}\text { Project } \\
\text { No. }\end{array}$} & \multicolumn{5}{|c|}{$\begin{array}{l}\text { Transverse Measurements } \\
\end{array}$} & \multicolumn{5}{|c|}{$\begin{array}{c}\text { Longitudinal Measurements } \\
\end{array}$} \\
\hline & \multicolumn{3}{|c|}{$\begin{array}{l}\text { Percent of Measurements } \\
\text { Greater than } 1 / 4 \mathrm{in.}\end{array}$} & \multicolumn{2}{|c|}{$\begin{array}{l}\text { Average Deviation } \\
\text { in. }\end{array}$} & \multicolumn{2}{|c|}{$\begin{array}{c}\text { Percent of Measure- } \\
\text { ments Greater } \\
\text { than } 1 / 8 \text { in. }\end{array}$} & \multicolumn{2}{|c|}{$\begin{array}{c}\text { Percent of Measure- } \\
\text { ments Greater } \\
\text { than } 1 / 4 \text { in. }\end{array}$} & \multirow{2}{*}{$\begin{array}{c}\text { Average } \\
\text { Deviation } \\
\text { in. } \\
\end{array}$} \\
\hline & $\begin{array}{r}\text { Lane } \\
\text { Positions } \\
\end{array}$ & $\frac{\text { terior }}{\text { Readings }}$ & $\begin{array}{c}\text { Lane } \\
\text { Edge }\end{array}$ & $\begin{array}{c}\text { Lane } \\
\text { Interior }\end{array}$ & $\begin{array}{l}\text { Lane } \\
\text { Edge }\end{array}$ & Positions & Readings & Positions & & \\
\hline 1 & 5 & 1 & 25 & 0.17 & 0.20 & 33 & 24 & 0 & 0 & 0.12 \\
\hline 2 & - & -- & 13 & -- & 0.18 & -- & -- & -- & -- & -- \\
\hline 3 & 36 & 20 & 10 & 0.18 & 0.10 & 48 & 61 & 3 & 2 & 0.17 \\
\hline 4 & $\begin{array}{l}5 \\
0 *\end{array}$ & $\begin{array}{l}7 \\
0 *\end{array}$ & $\begin{array}{l}65 \\
41^{*}\end{array}$ & $\begin{array}{l}0.17 \\
0.14^{*}\end{array}$ & $\begin{array}{l}0.37 \\
0.24^{*}\end{array}$ & 69 & 65 & 19 & 18 & 0.21 \\
\hline 5 & $\begin{array}{l}-- \\
-- \\
-- \\
--\end{array}$ & $\begin{array}{l}-- \\
-- \\
--\end{array}$ & $\begin{array}{l}71 * * \\
57^{* * *} \\
13 \dagger \\
6^{*} \dagger\end{array}$ & $\begin{array}{l}-- \\
-- \\
-- \\
--\end{array}$ & $\begin{array}{l}0.40^{* *} \\
0.32^{* * *} \\
0.18 \dagger \\
0.10^{*} \dagger\end{array}$ & $\begin{array}{l}-- \\
-- \\
--\end{array}$ & $\begin{array}{l}-- \\
-- \\
--\end{array}$ & $\begin{array}{l}-- \\
-- \\
--\end{array}$ & $\begin{array}{l}-- \\
-- \\
--\end{array}$ & $\begin{array}{l}-- \\
-- \\
--\end{array}$ \\
\hline 6 & -- & -- & -- & -- & -- & -- & -- & -- & -. & -- \\
\hline 7 & -- & -- & -- & -- & -- & 60 & 24 & 3 & 1 & 0.12 \\
\hline 8 & $\begin{array}{l}0 \\
0^{*}\end{array}$ & $\begin{array}{l}0 \\
0^{*}\end{array}$ & $\begin{array}{c}3 \\
32^{*}\end{array}$ & $\begin{array}{l}0.12 \\
0.14^{*}\end{array}$ & $\begin{array}{l}0.16 \\
0.21^{*}\end{array}$ & 37 & 26 & 2 & 1 & 0.14 \\
\hline 9 & $\begin{array}{l}8 \\
4 *\end{array}$ & $\begin{array}{l}-- \\
--\end{array}$ & $\begin{array}{l}46 \\
33^{*}\end{array}$ & $\begin{array}{l}-- \\
--\end{array}$ & $\begin{array}{l}0.30 \\
0.19^{*}\end{array}$ & $\begin{array}{l}54 \\
--\end{array}$ & -- & $\begin{array}{l}12 \\
--\end{array}$ & $\begin{array}{l}-- \\
--\end{array}$ & -- \\
\hline
\end{tabular}

* Measurements on fill-in lanes, others on slipform lanes.

** Runway pavement.

+ Taxiway pavement. 


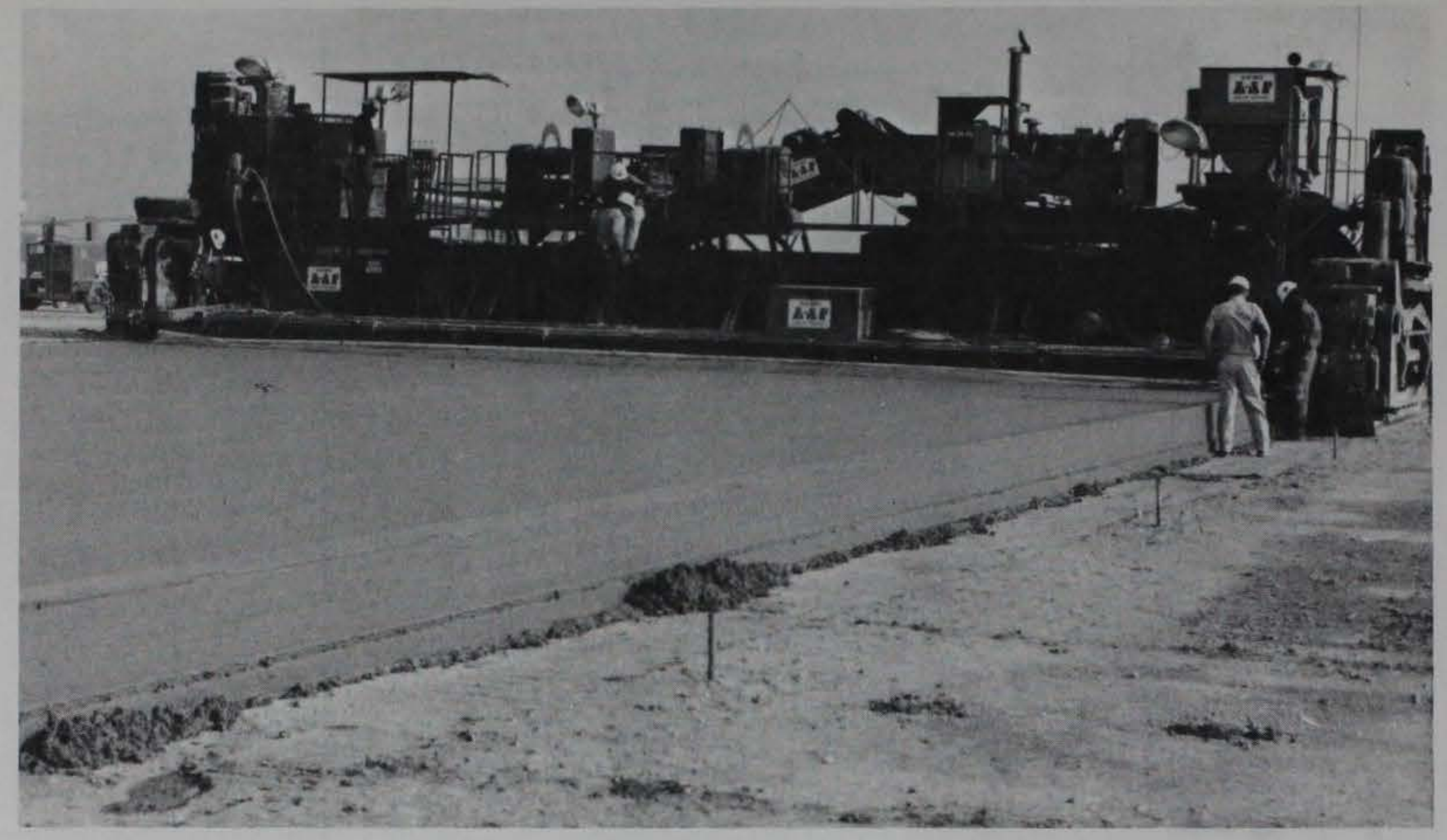

(Courtesy of Guntert and Zimmerman Construction Division, Inc.)

Photo 1. Example of Guntert and Zimmerman slipform paver

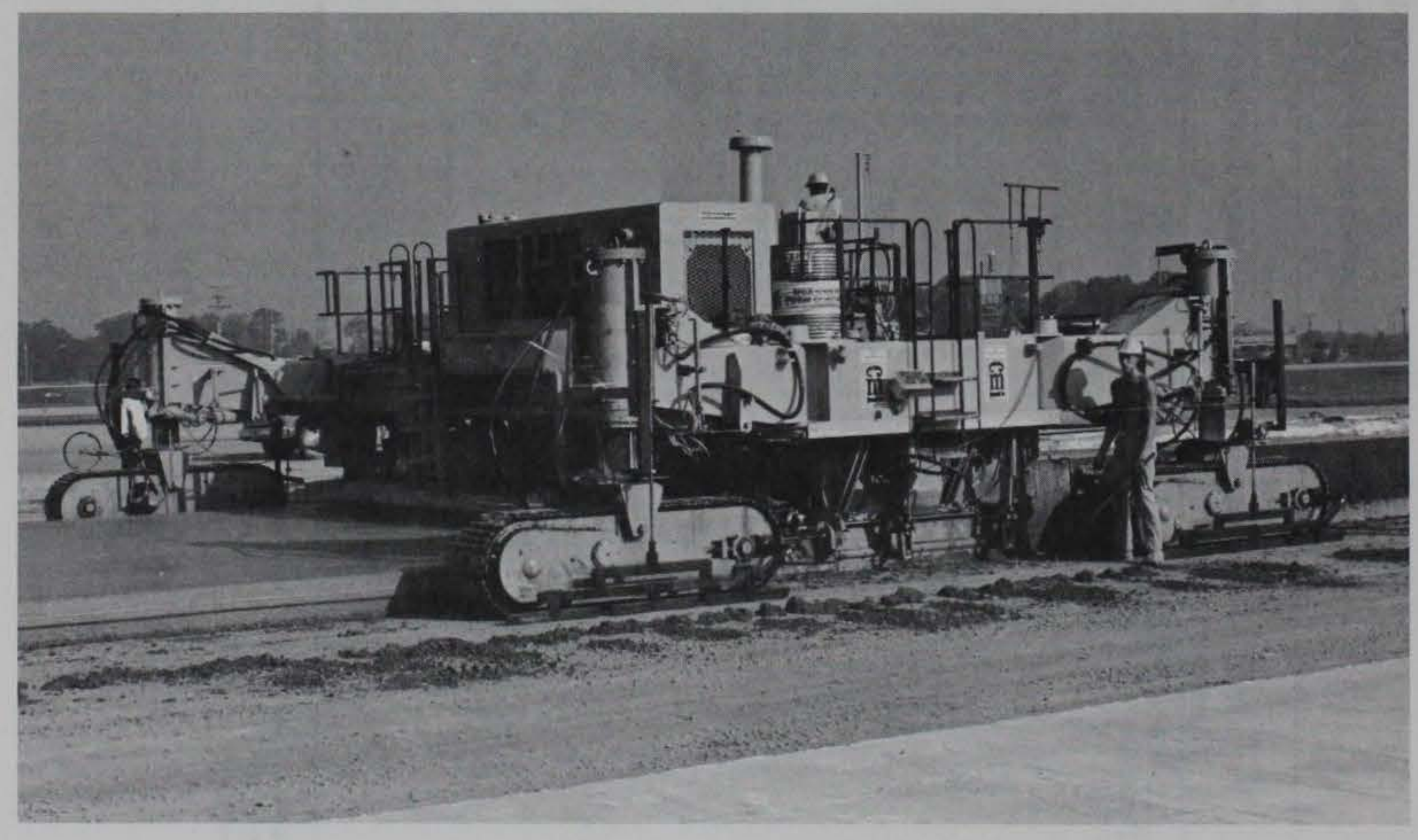




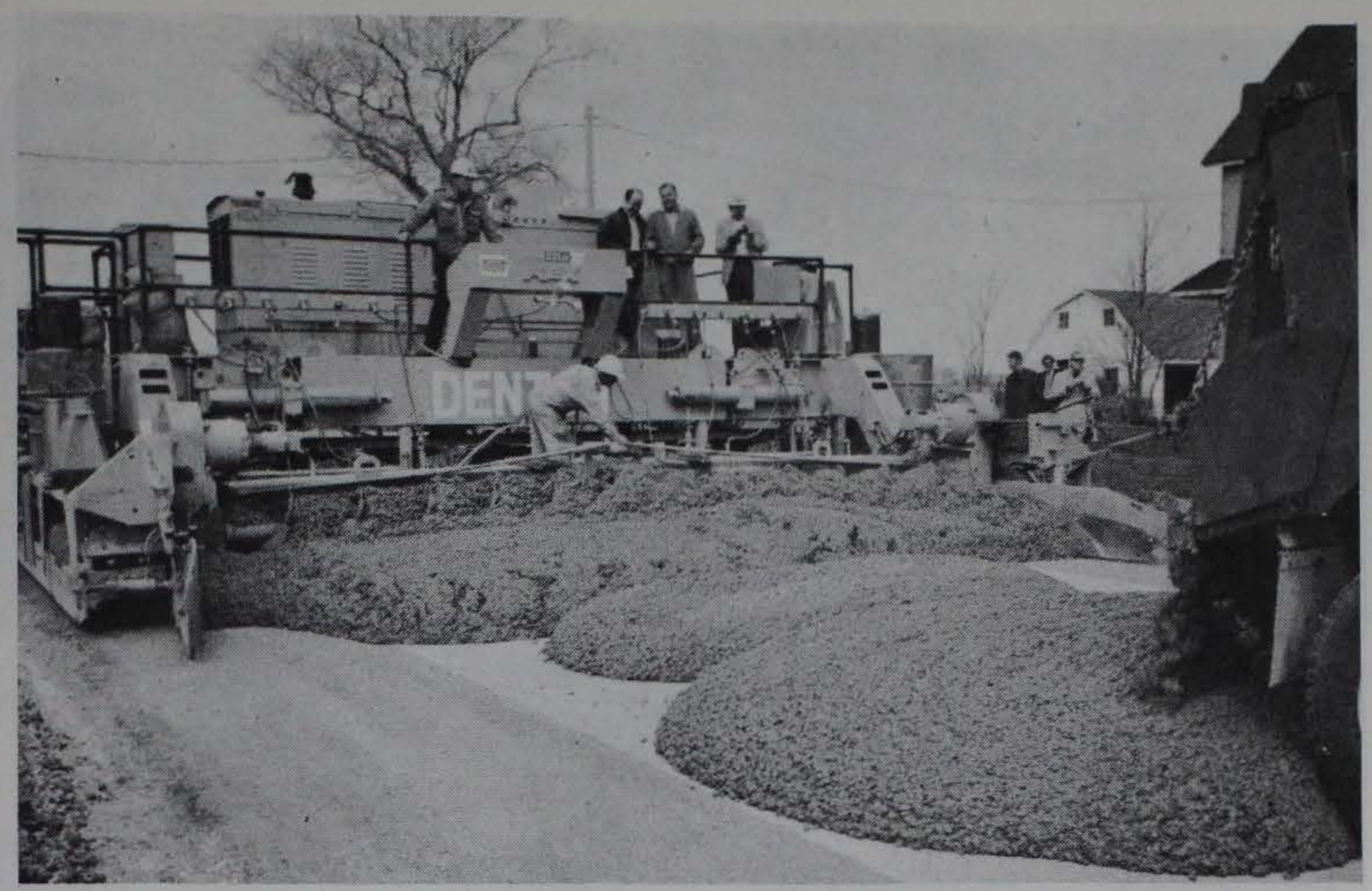

(Courtesy Rexnord, Inc.)

Photo 3. Example of Rex slipform paver

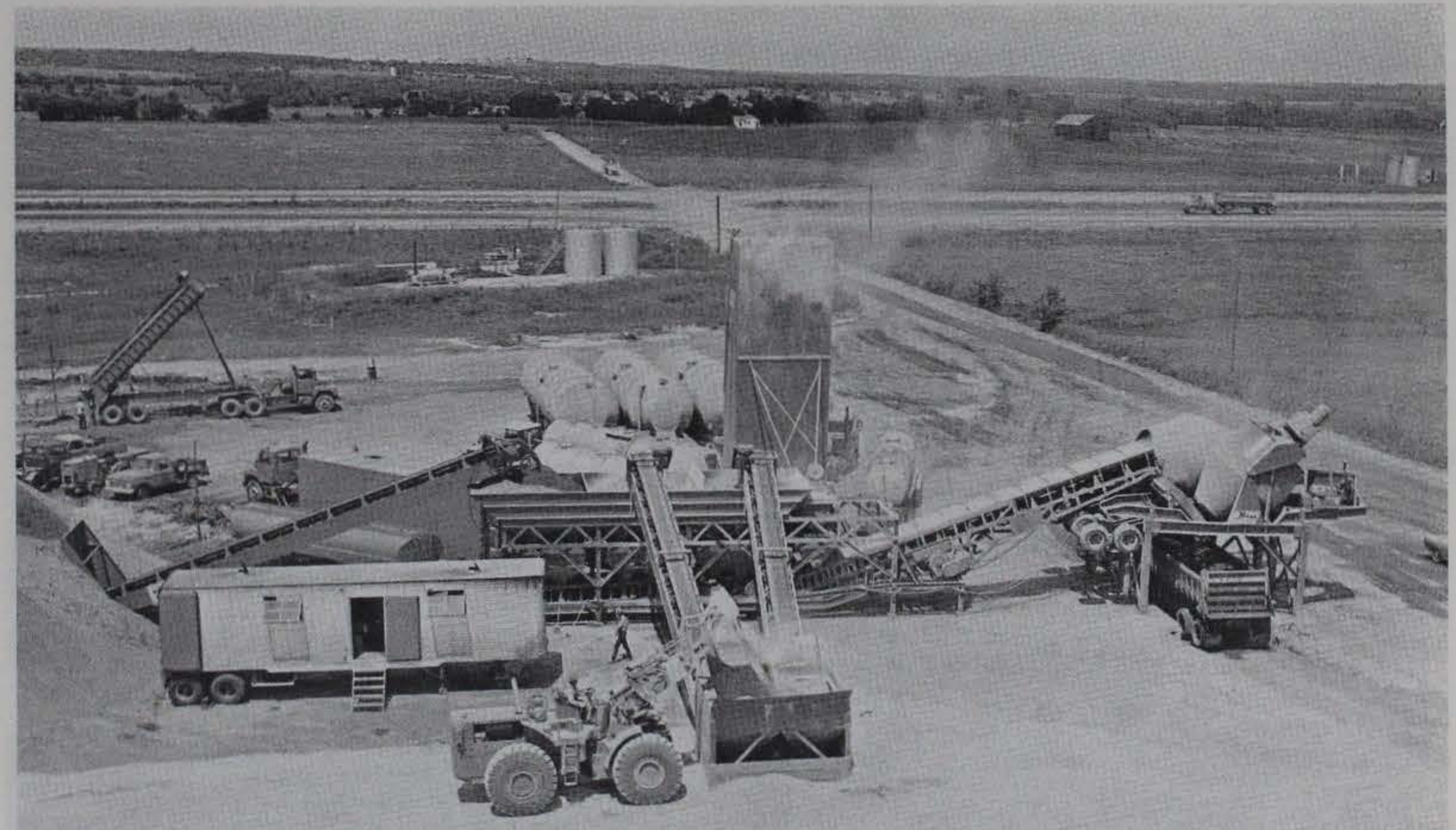




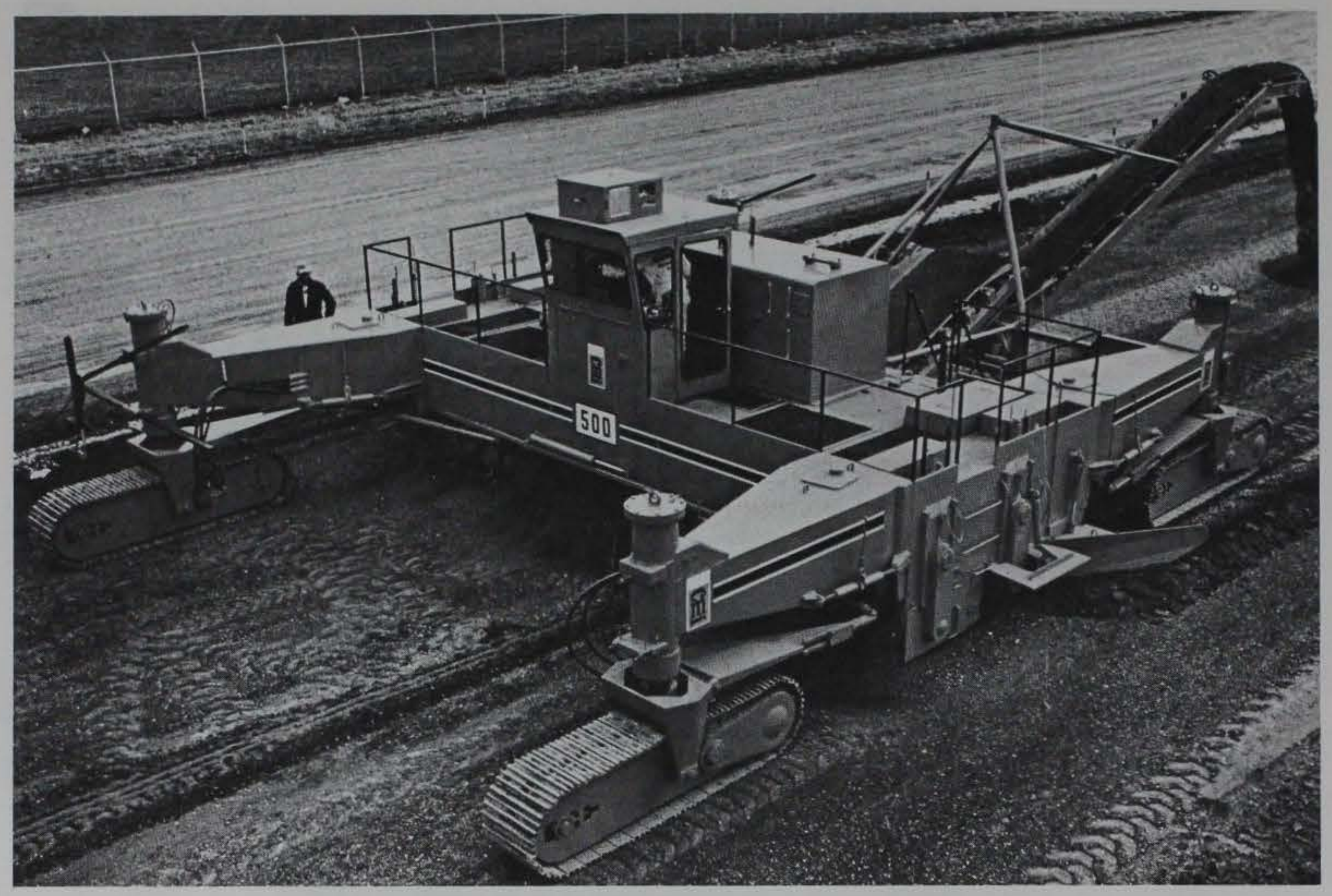

Photo 5. Example of automatically controlled fine-grading equipment

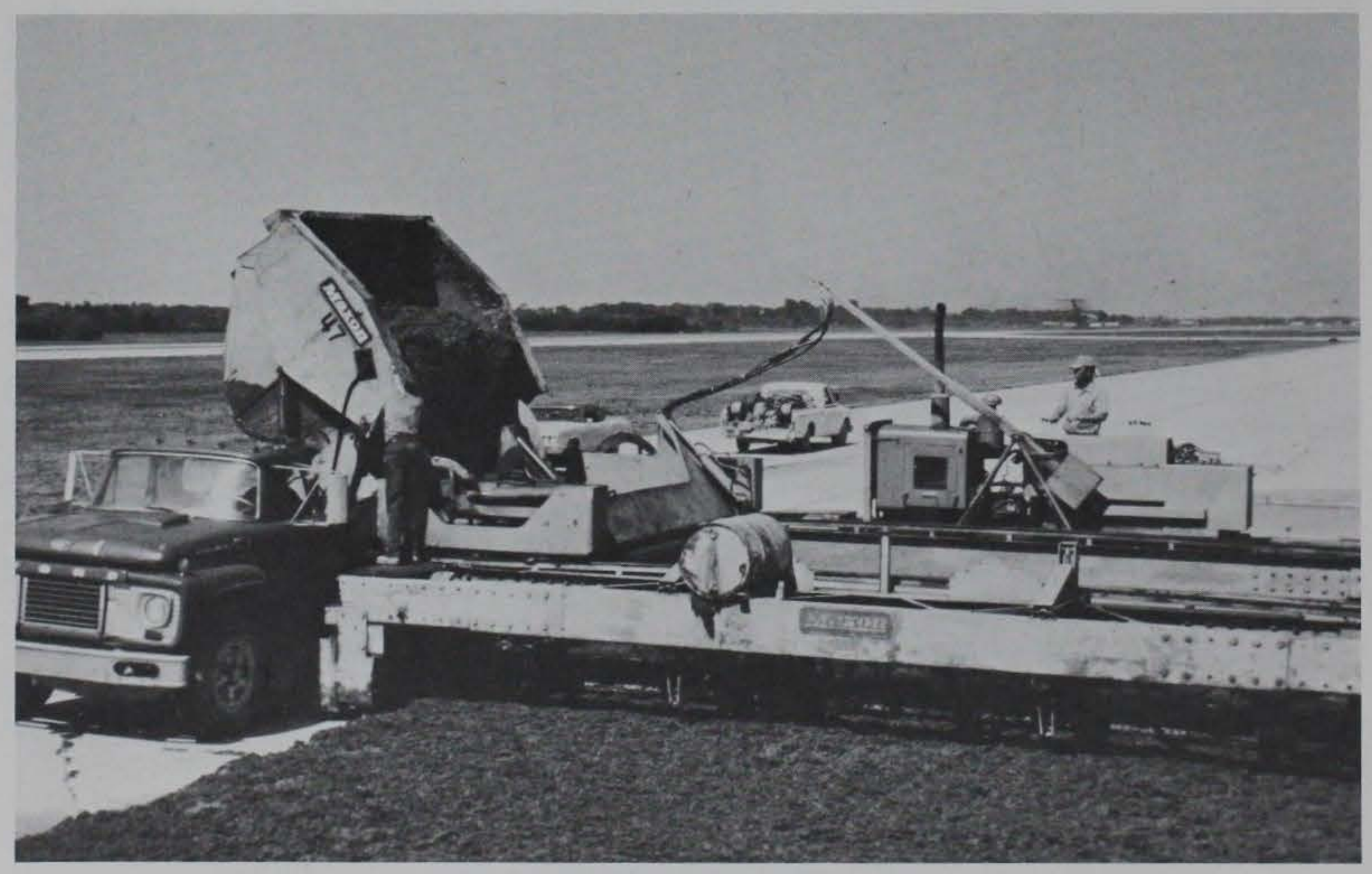

Photo 6. Example of haul equipment 


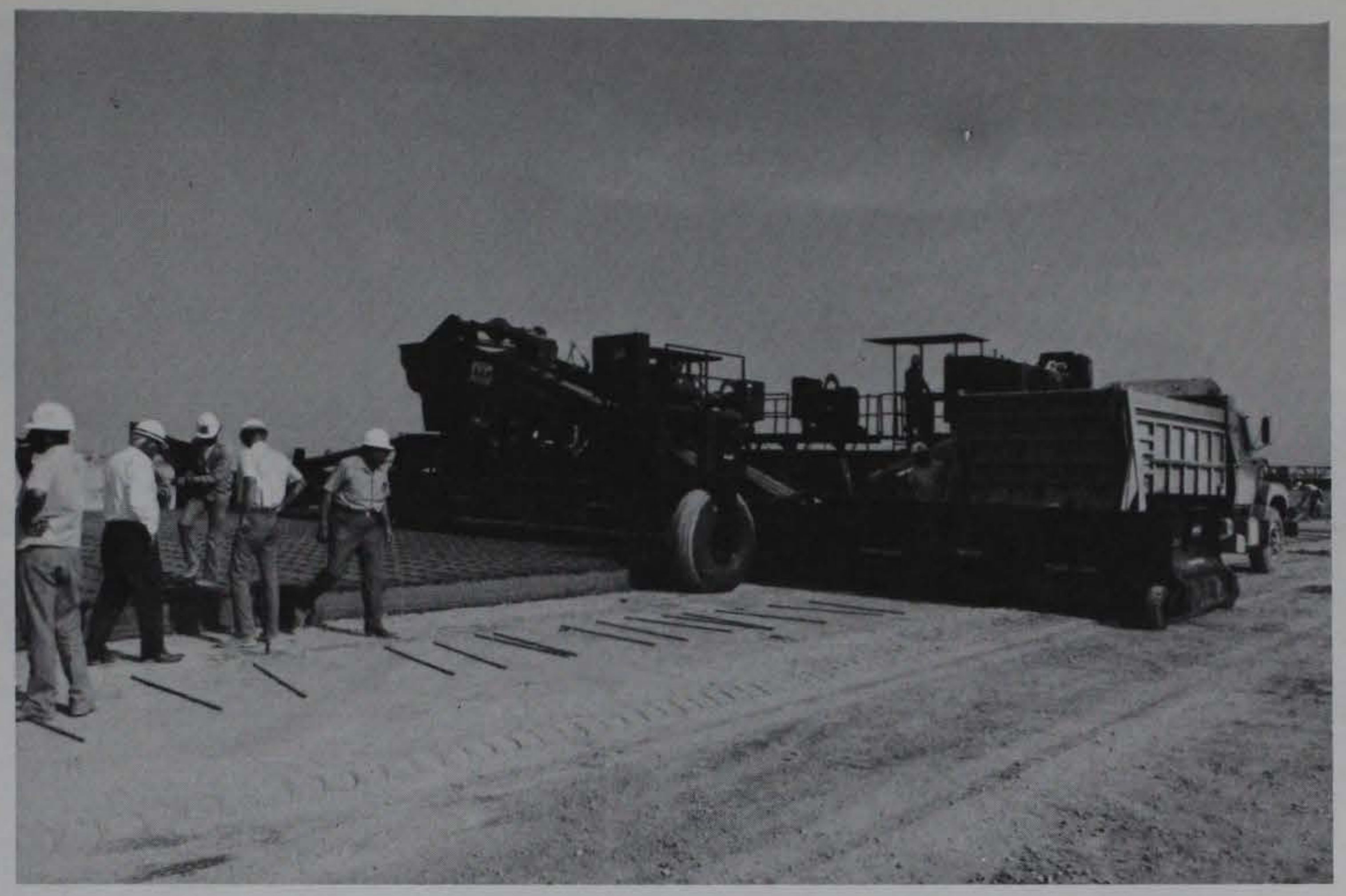

Photo 7. Typical belt-type spreader attached to paver

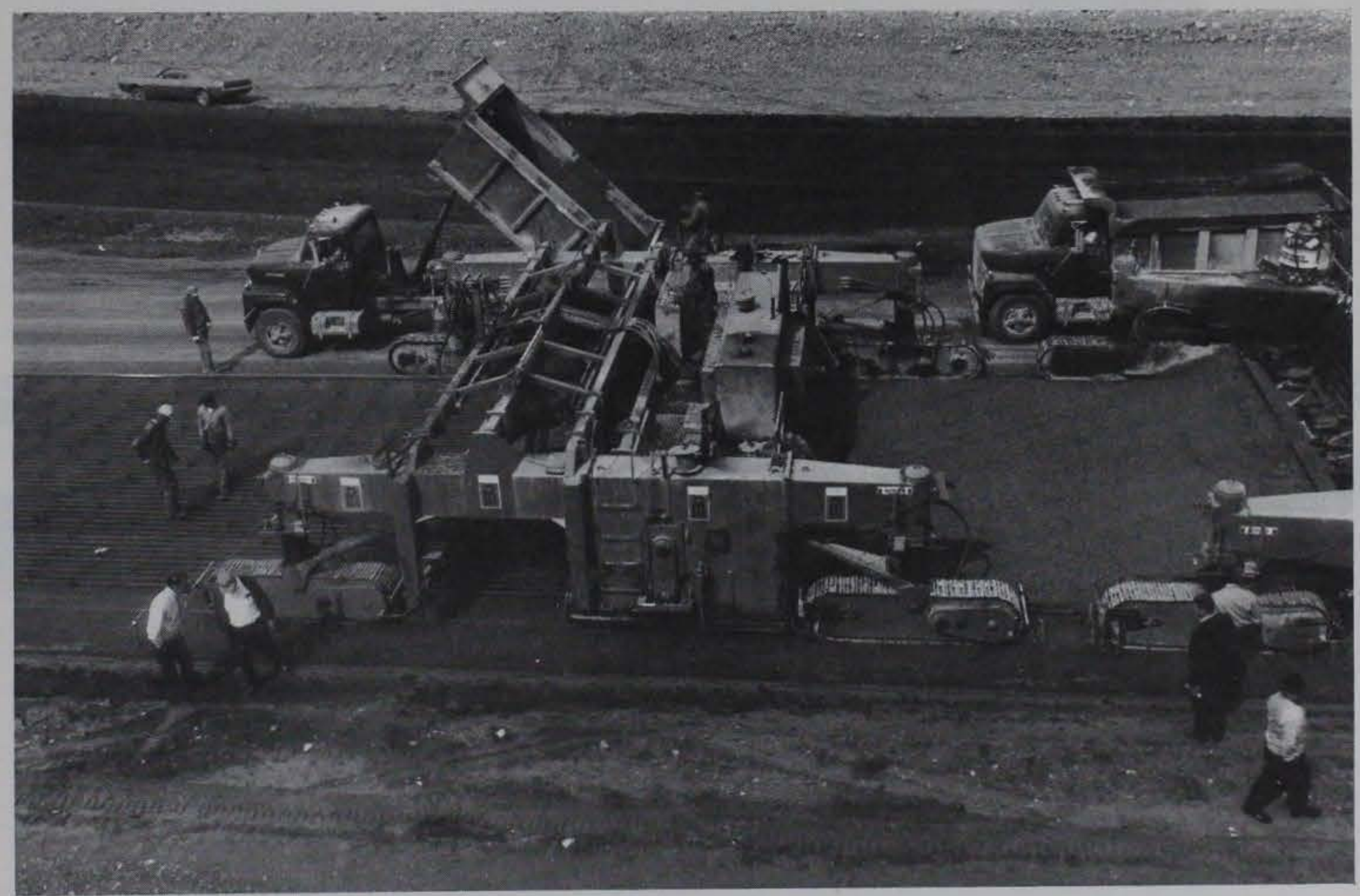

Photo 8. Typical combination belt-and-auger spreader 

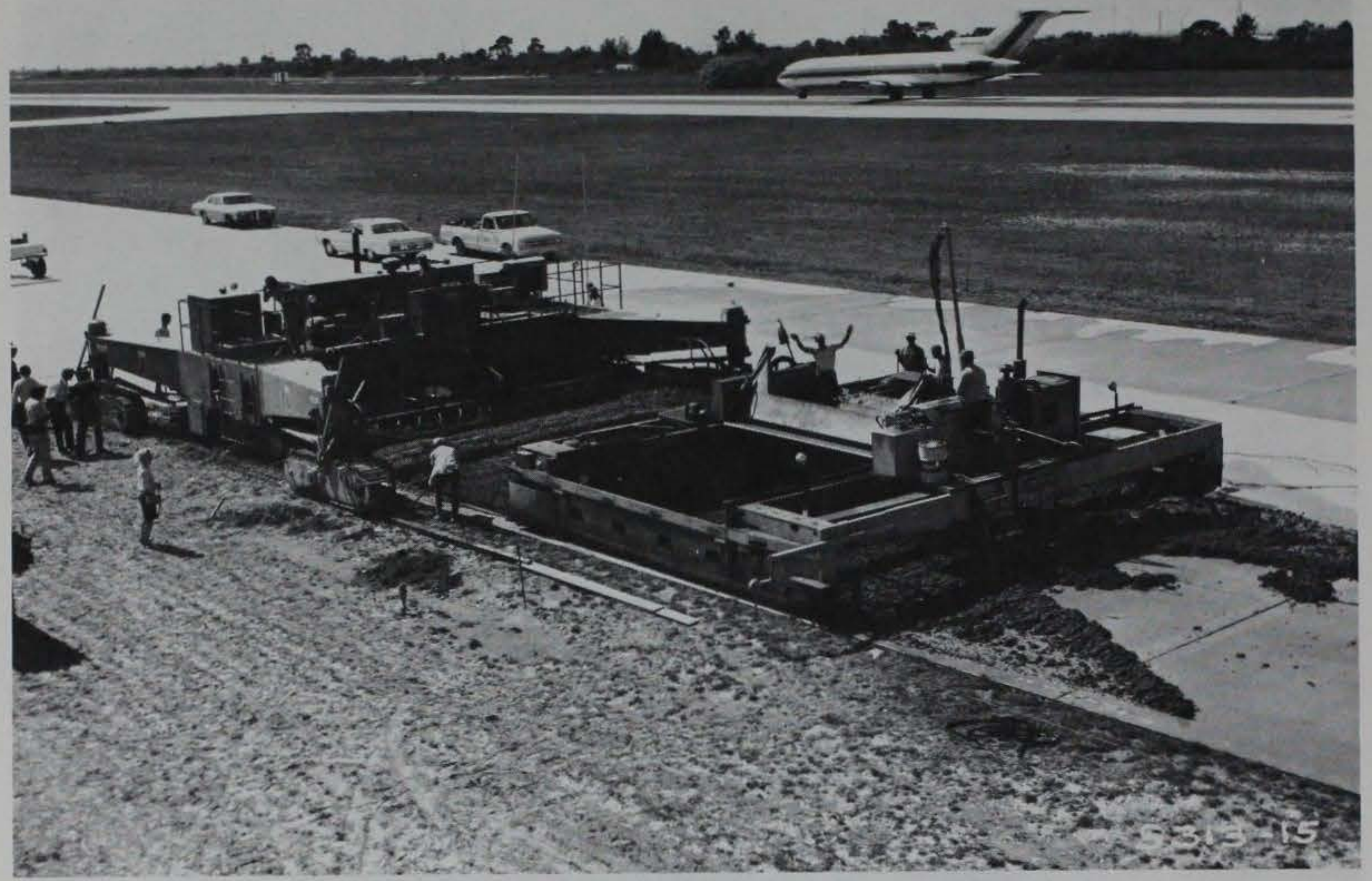

Photo 9. Typical box spreader

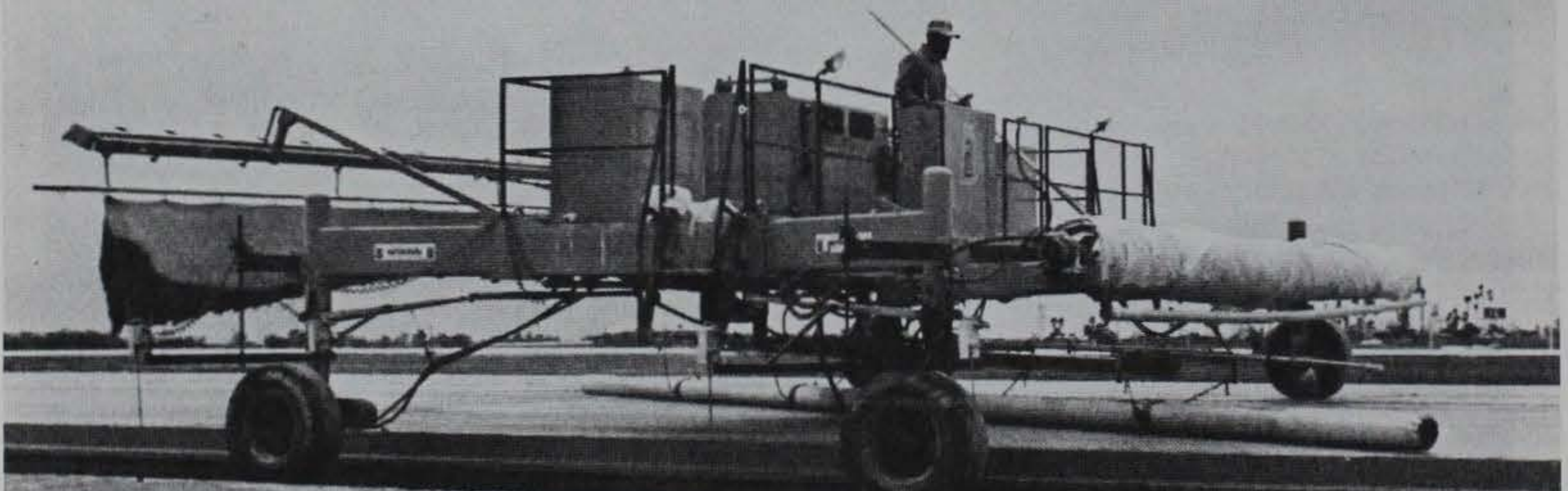

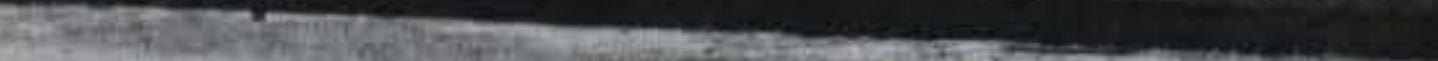

L 


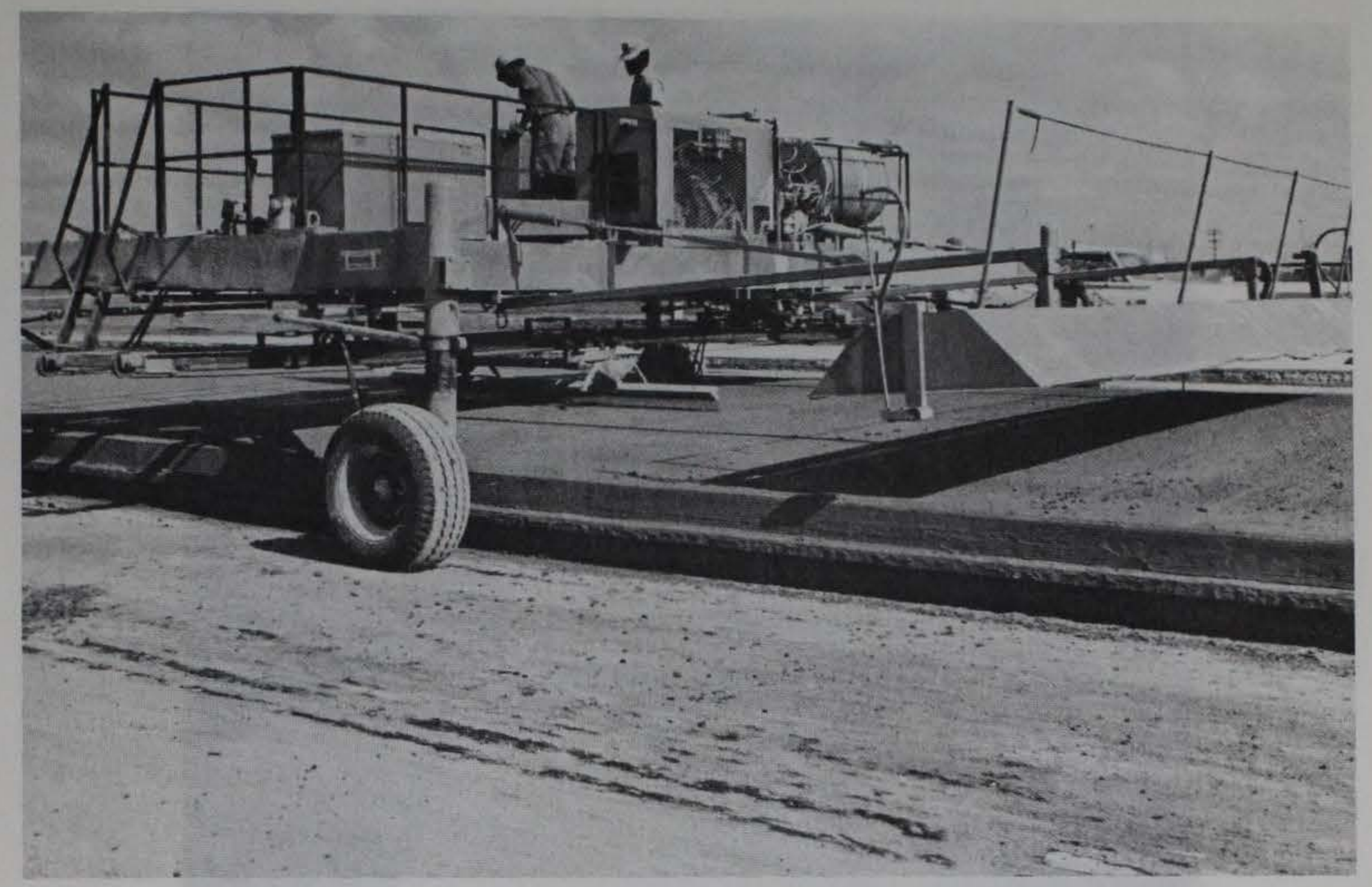

Photo 11. Typical texture-curing compound applicator

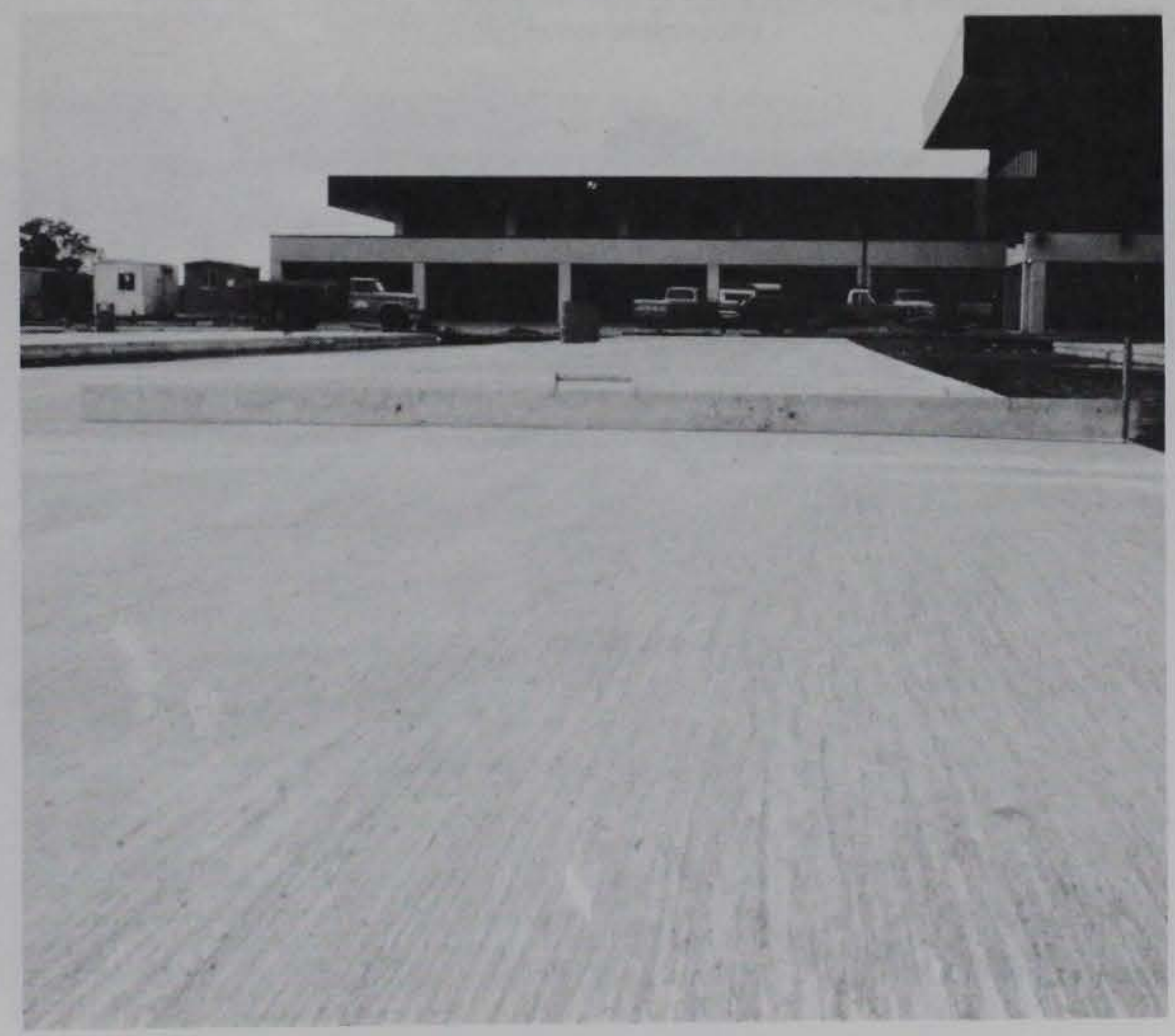

Photo 12. Placement of straightedge perpendicular to and along edge of slip-formed lane 


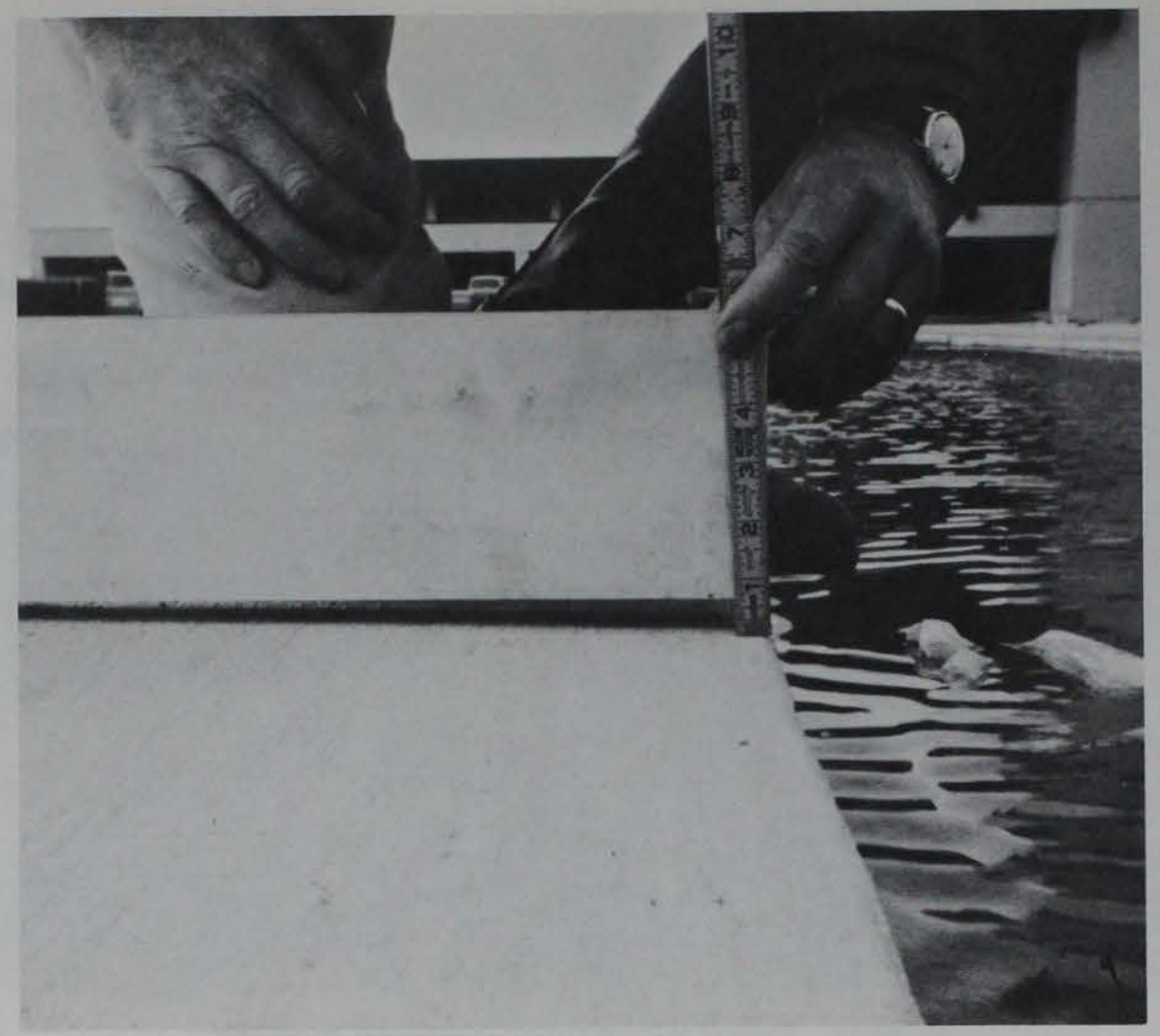

Photo 13. Measurement of slump along edge of slipformed lane

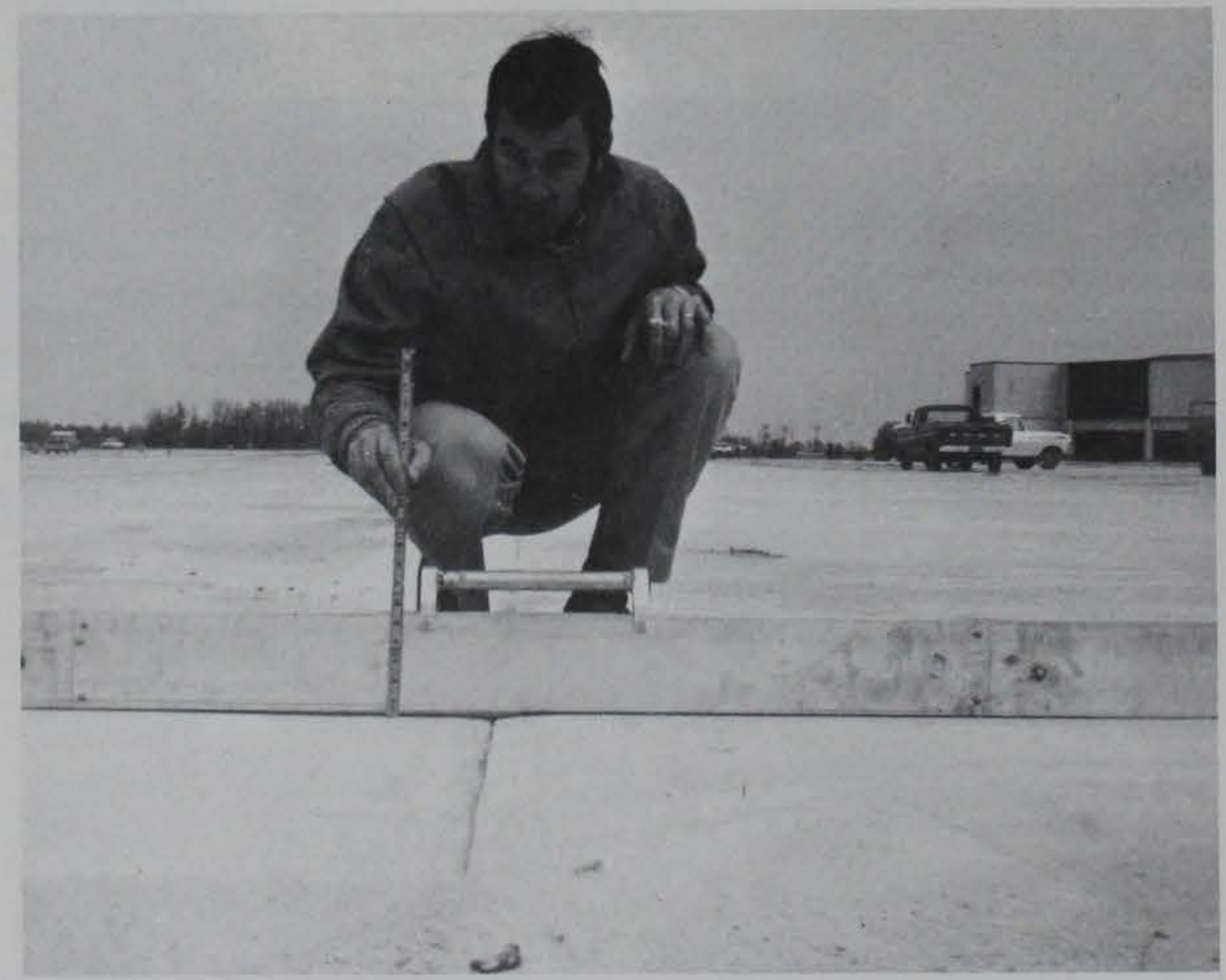

Photo 14. Placement of straightedge across longitudinal construction joint 


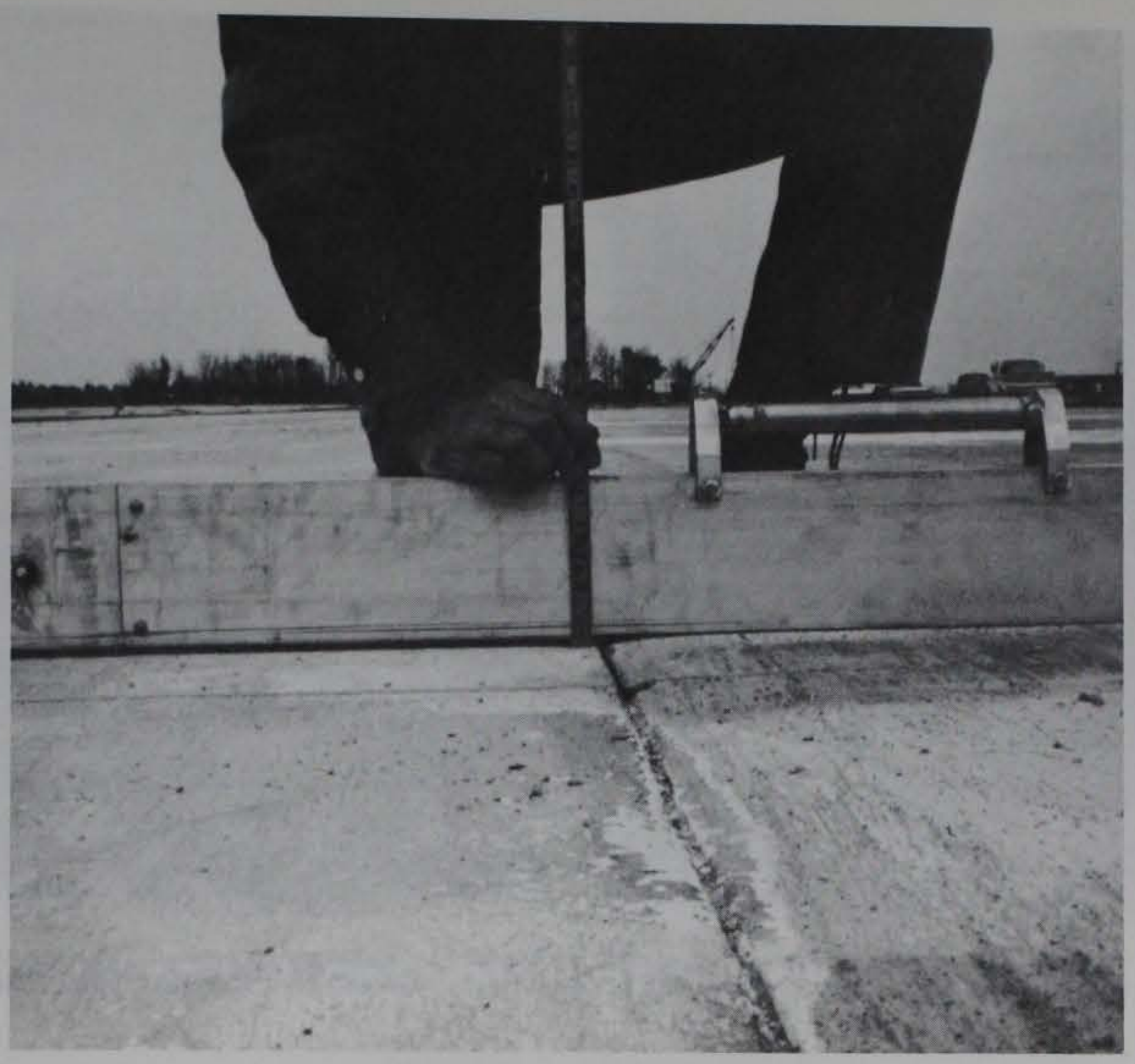

Photo 15. Close-up of measurement of deviation along a longitudinal construction joint

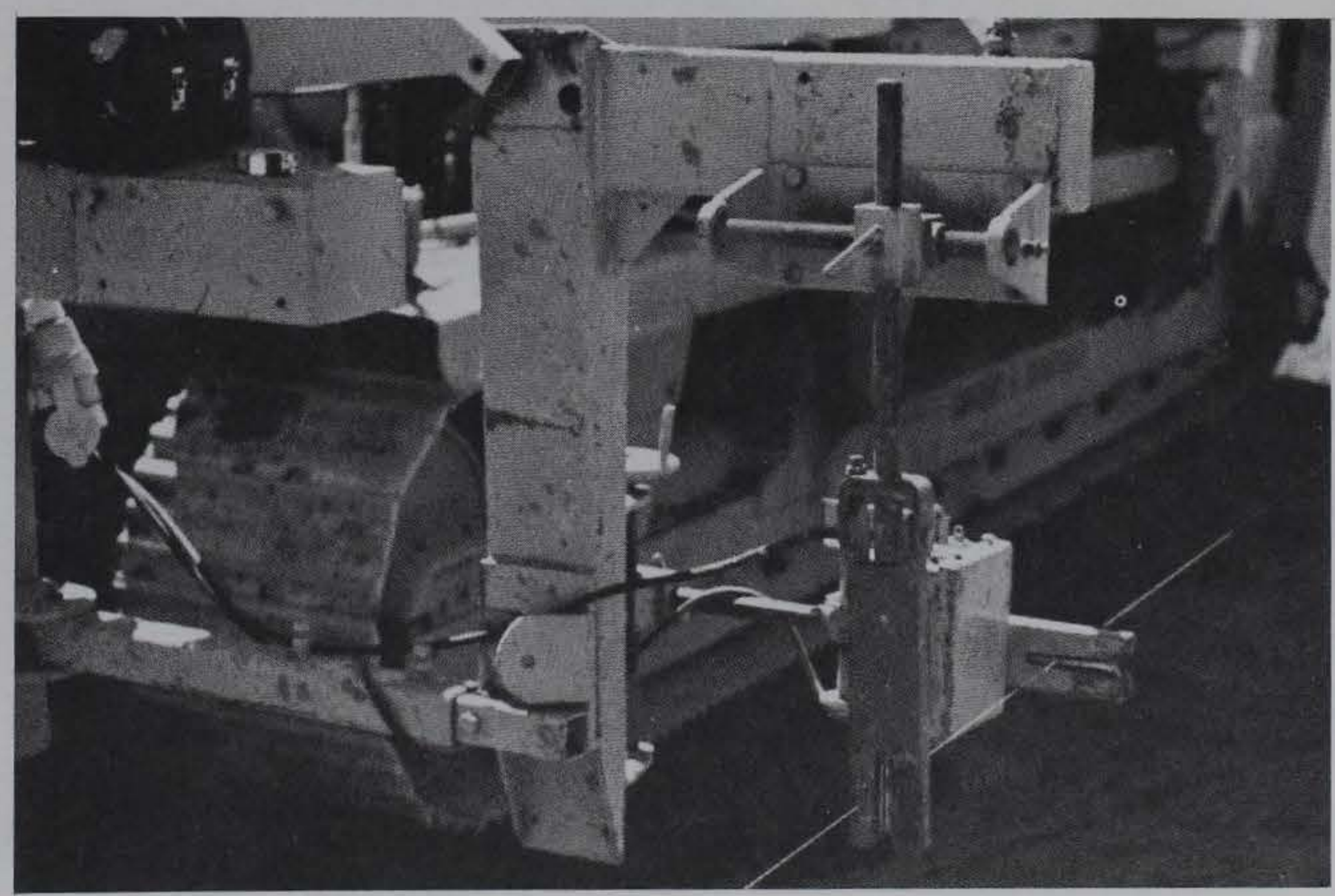

Photo 16. Example of sensors used with stringline 


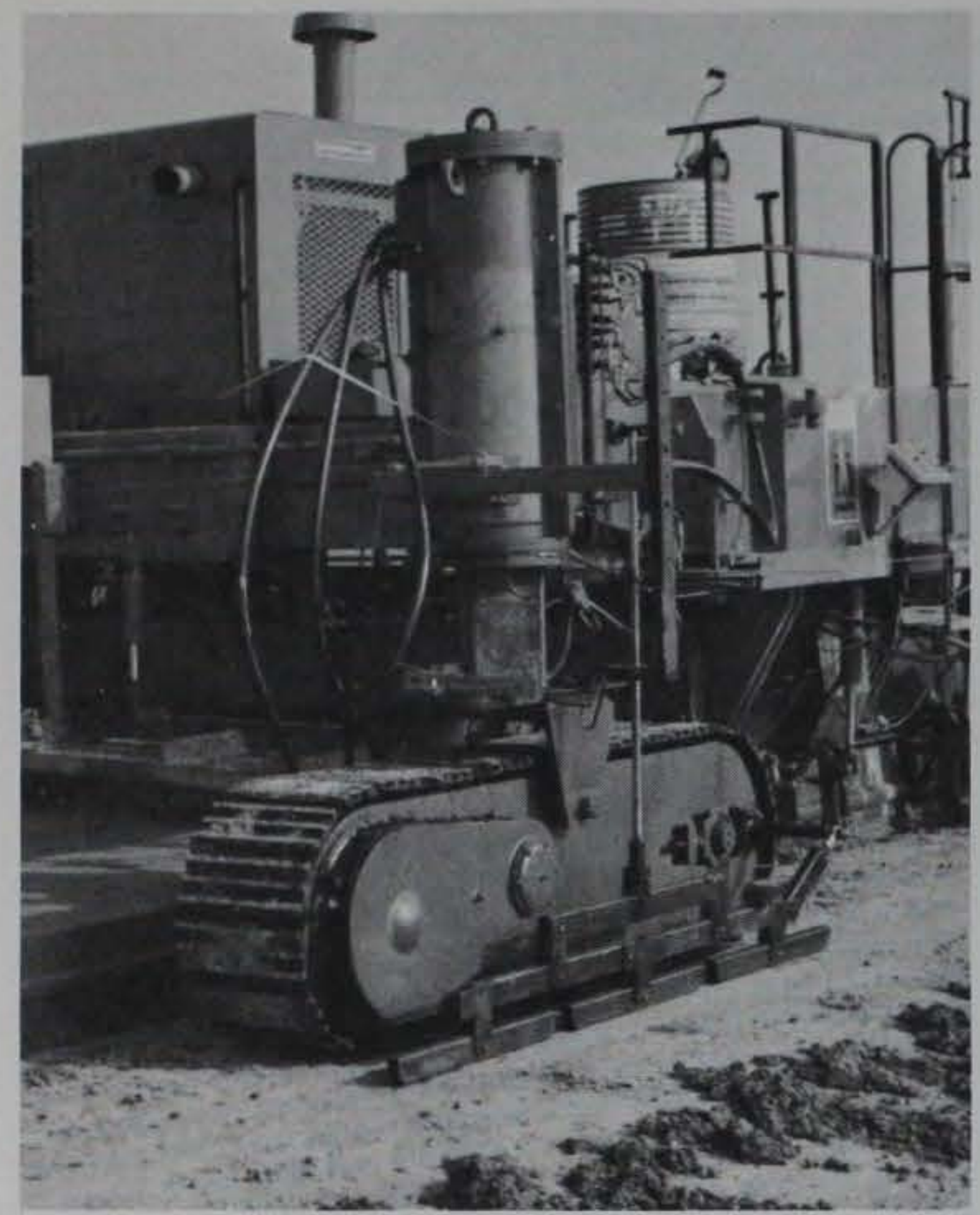

Photo 17. Example of sensor used when reference is preformed surface

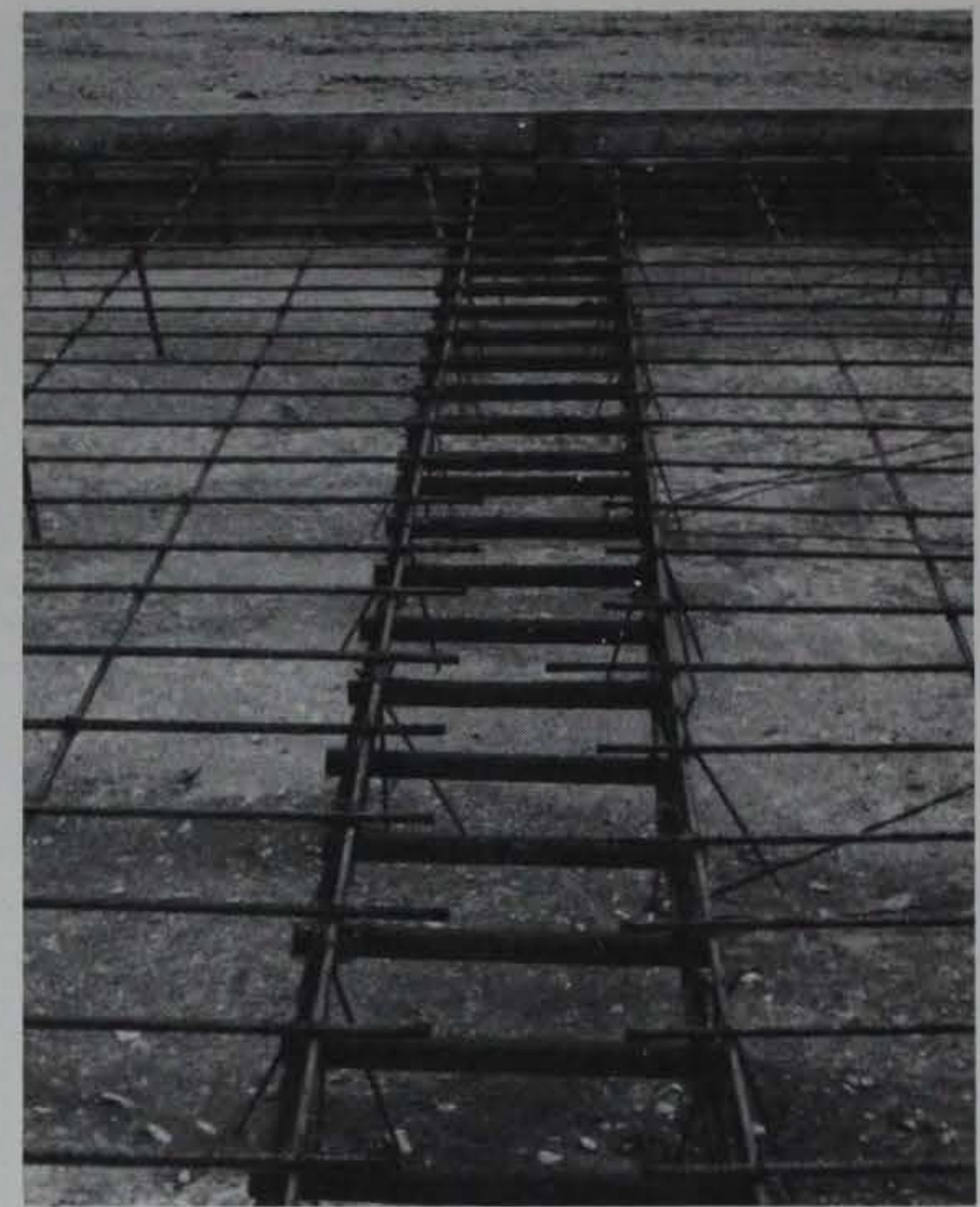

Photo 18. Reinforcing steel and dowel assembly preset and ready for concrete placement

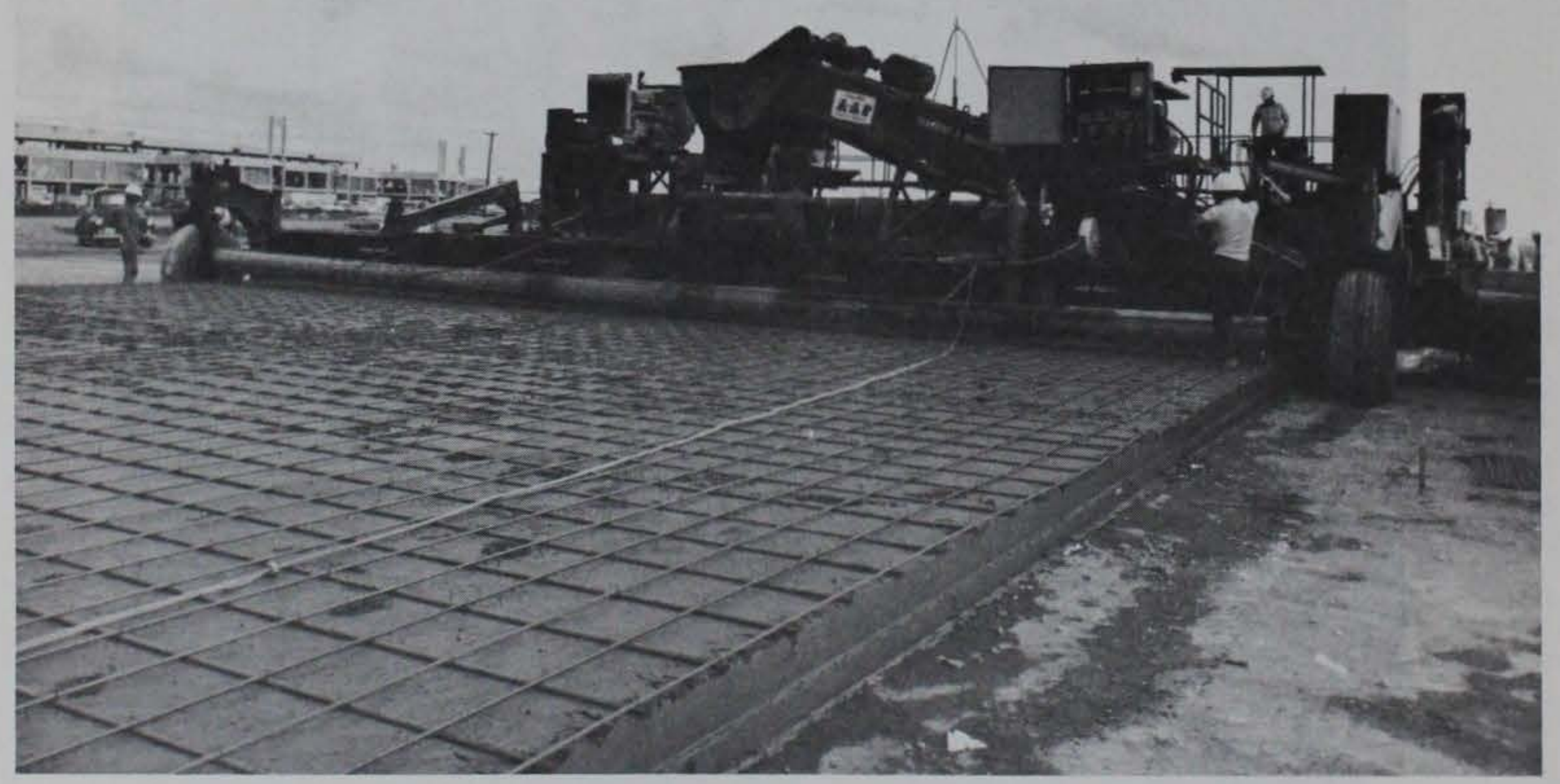

Photo 19. First lift and steel in place; spreader and paver placing second lift 


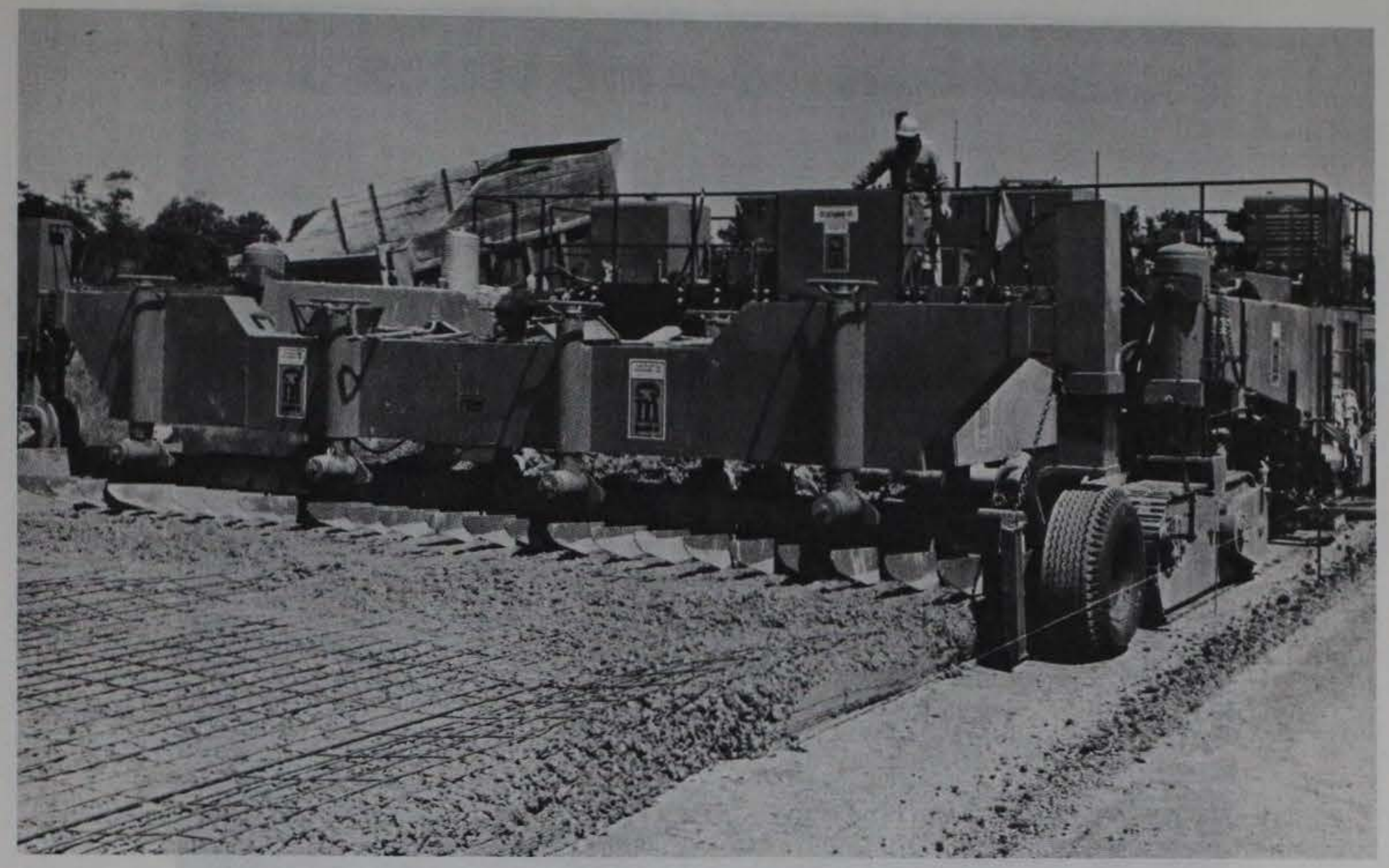

Photo 20. Wire mesh being depressed to desired elevation in unconsolidated concrete

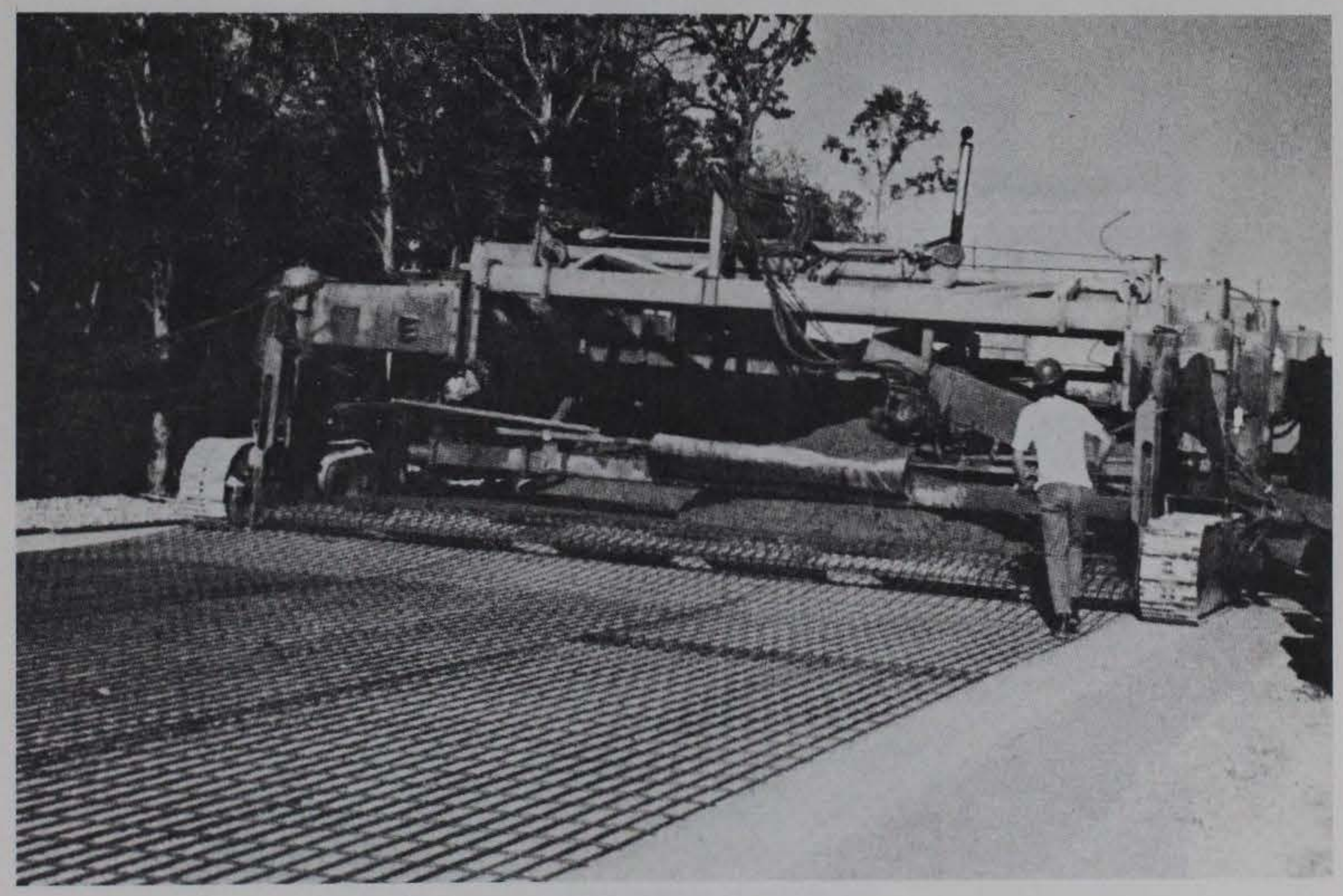

Photo 21. Reinforcing steel (bar mats) being lifted and held in position while concrete is placed 


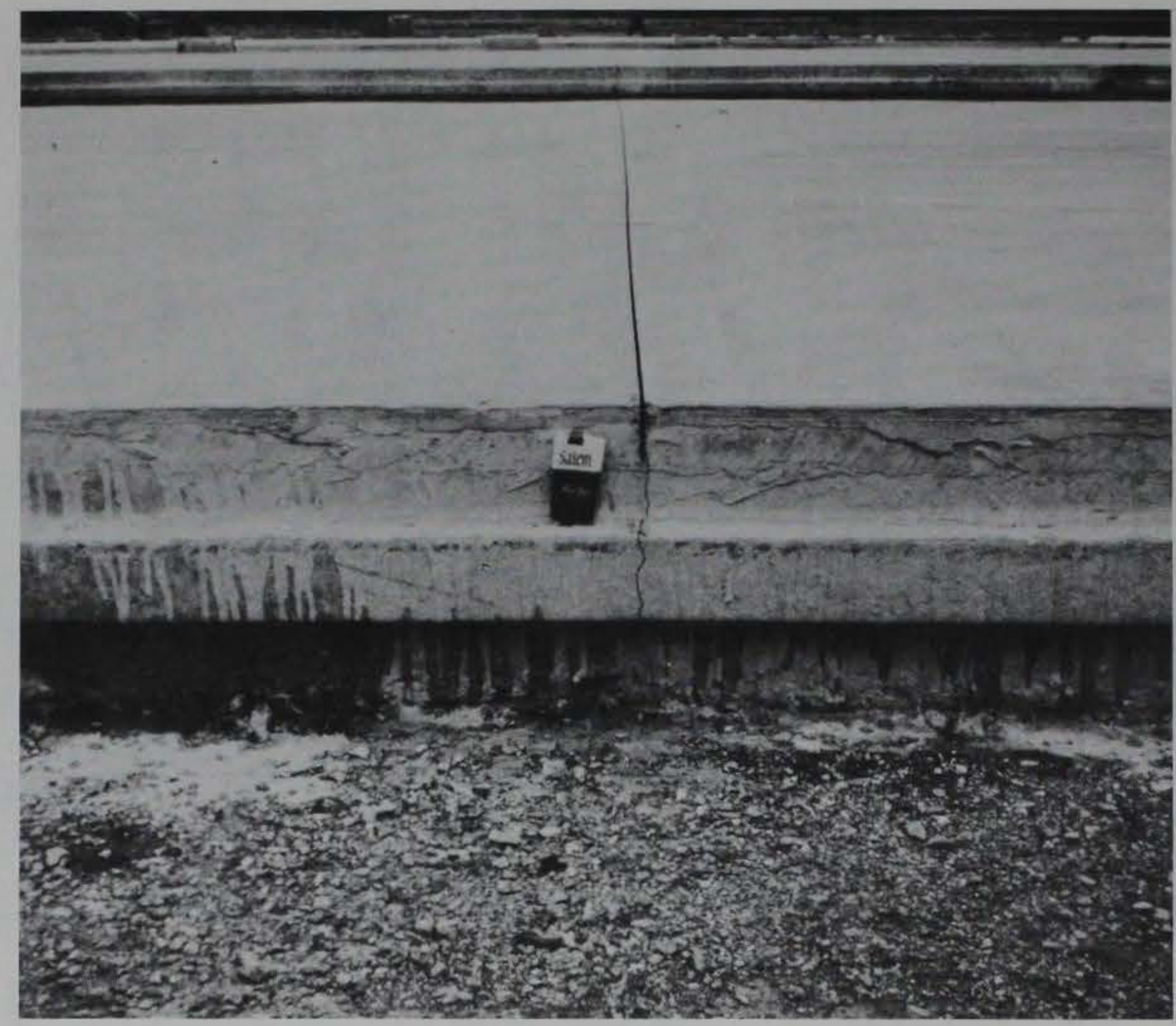

a. Good construction
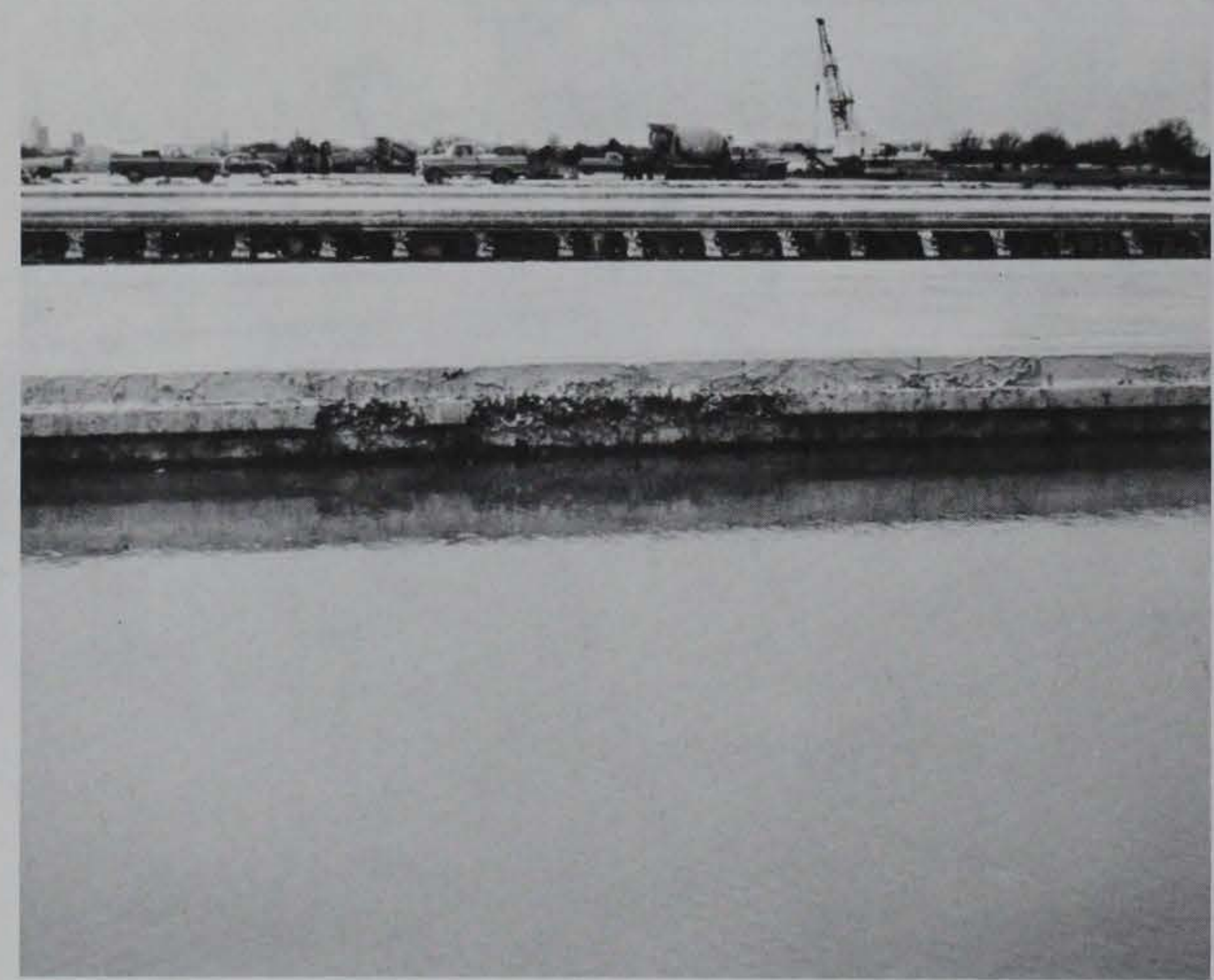

b. Poor construction

Photo 22. Examples of key construction 


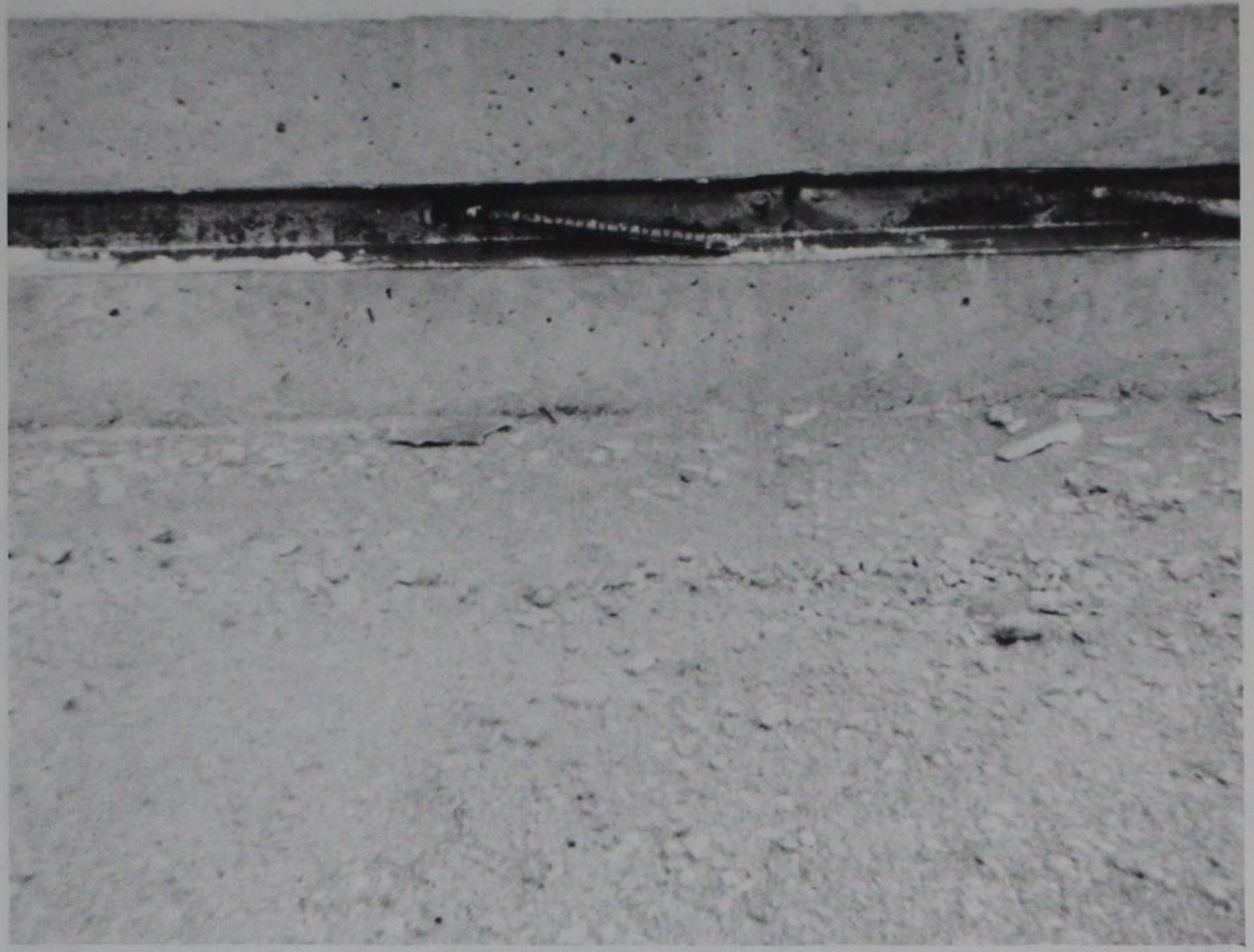

a. Good keyway construction with metal liner and bent tie bars

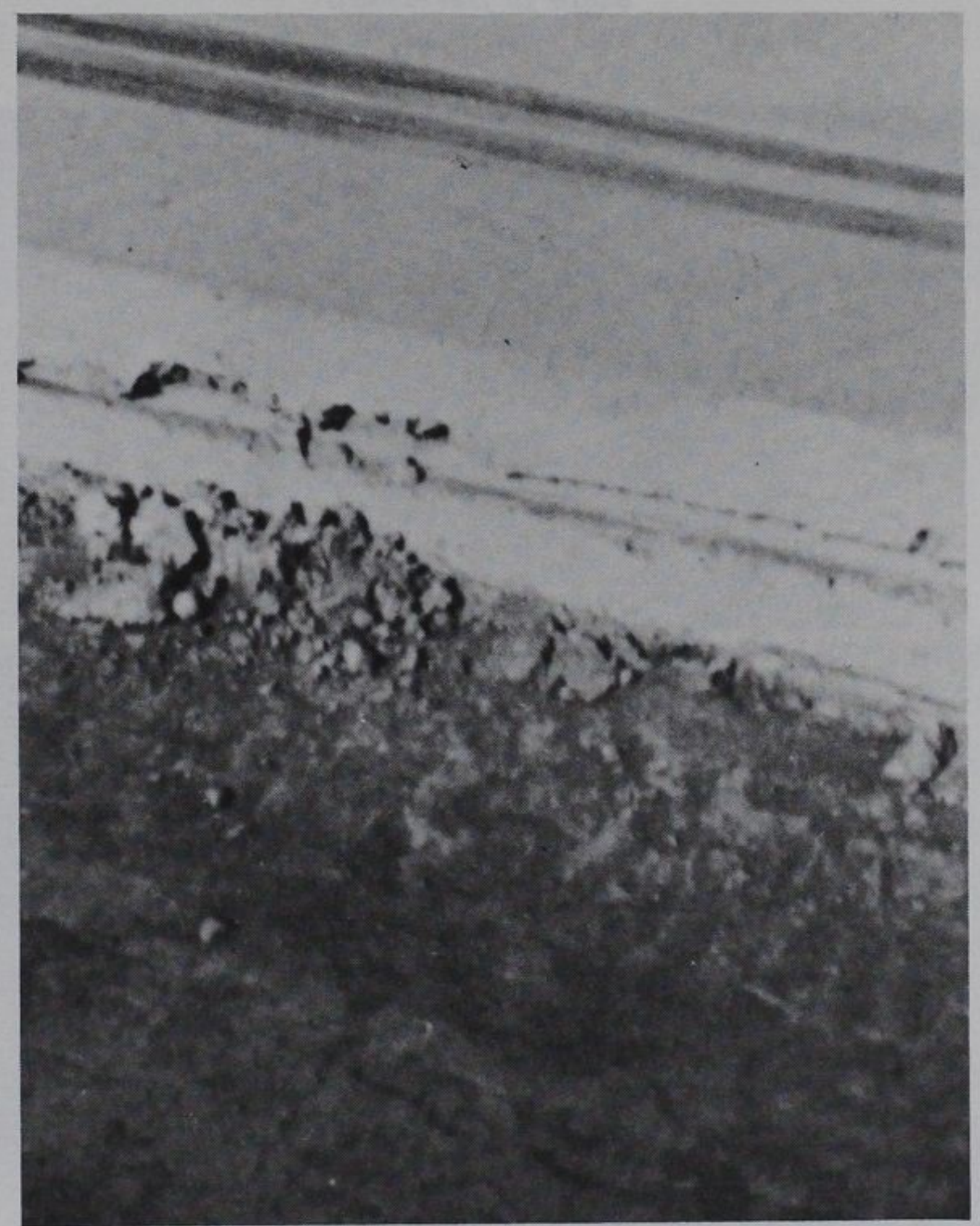

b. Poor keyway construction 


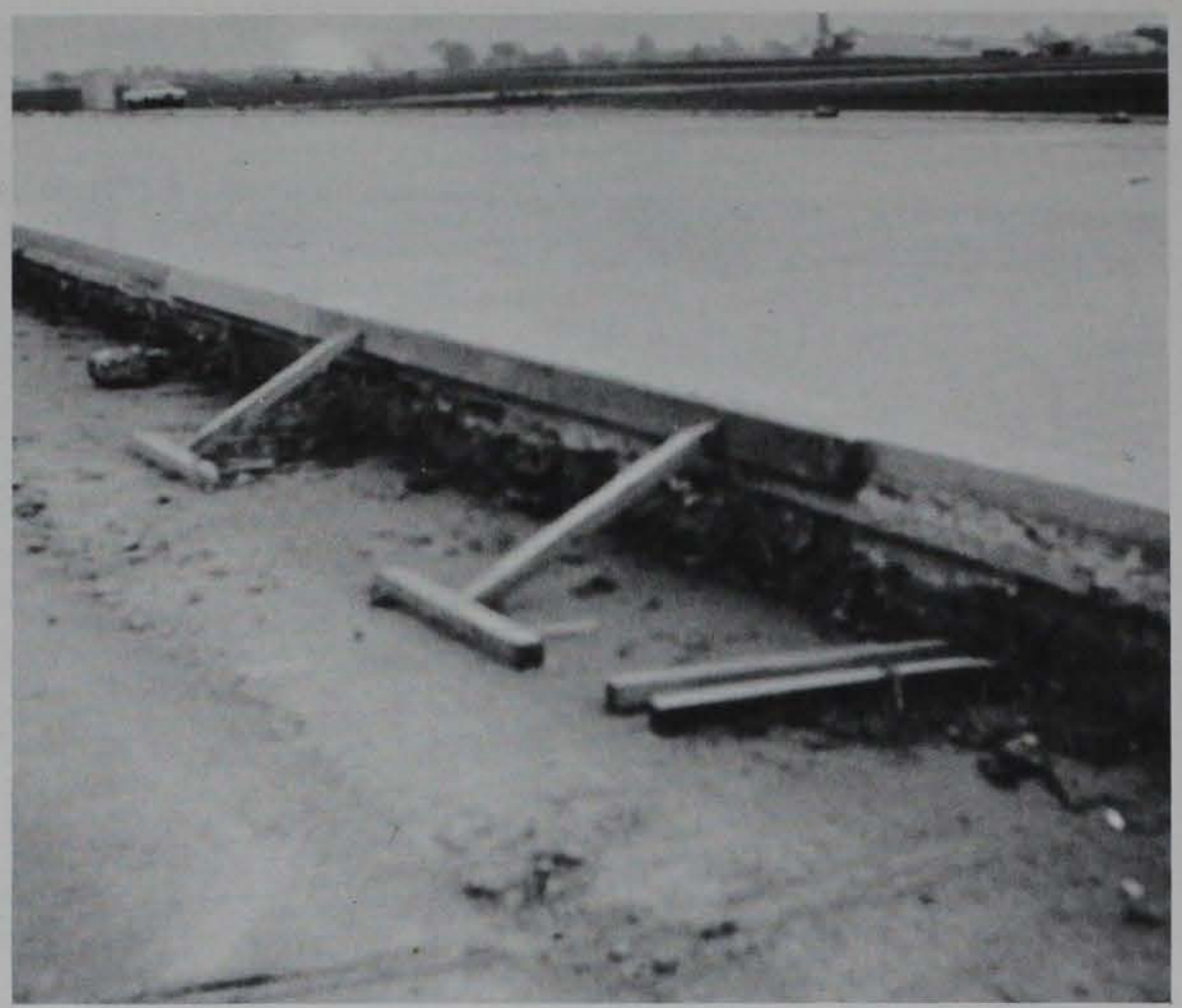

Photo 24. Example of method for providing lateral support to edge of pavement

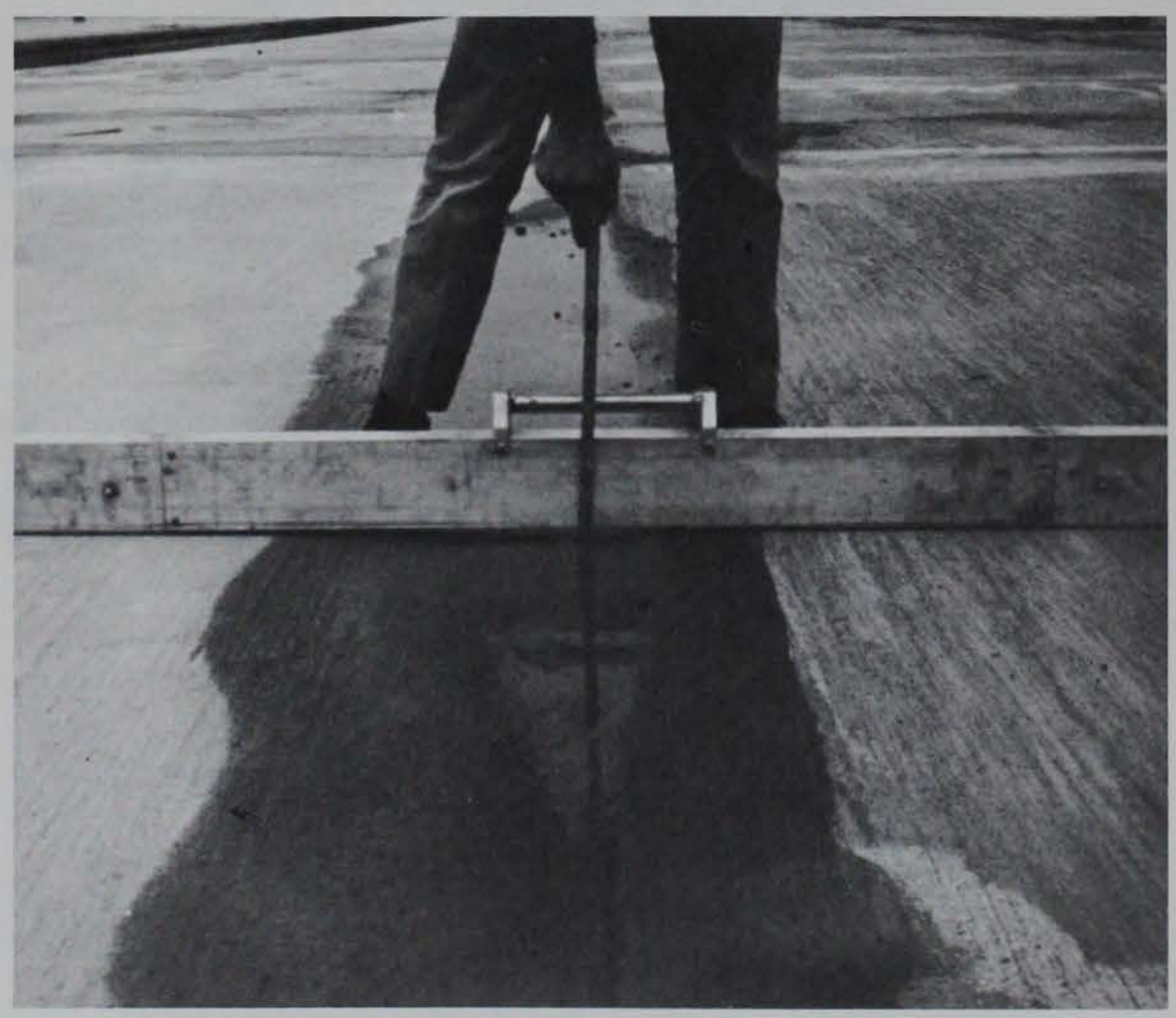

Photo 25. Collection of water along longitudinal construction joint 


\section{APPENDIX A: FIELD OBSERVATION}

1. This appendix contains the details of the field observations and a summary of the surface smoothness measurements made on nine construction projects.

\section{PROJECT 1}

2. On 18 August 1971 , the construction of a 146-ft-wide overlay of an existing concrete runway was observed. Details of the runway construction are given in the following paragraphs.

\section{Runway Description}

3. The runway was $146 \mathrm{ft}$ wide and consisted of an 11-1/2-in. mesh reinforced PCC overlay of an existing 150 -ft-wide concrete runway.

\section{Base Course}

4. The base for the overlay consisted of a 1-1/2-in. asphalt sand leveling course over an old 8-in. PCC pavement.

\section{Mix Design}

5. The mix, designed for a seven-day flexural strength of $700 \mathrm{psi}$, consists of $580 \mathrm{lb} / \mathrm{yd}^{3}$ of cement with 55 percent coarse aggregate and 45 percent sand. The contractor tried to maintain a slump of approximately 1 in. An air-entraining agent was used with 6 percent entrained air specified. The aggregate was a crushed limestone with a maximum size of $1 / 2$ in.

\section{Paving and Batch Equipment}

6. A fully automatic Rex batch plant with an 11-cu-yd drum capacity was used; a 60-sec mix time was specified. The paving train consisted of a Rex spreader, a tilting trailer for hauling and placing wire mesh, a Rex slipform paver, a pipe float, a burlap drag, a transverse broom, and a curing compound applicator. Horizontal alignment was automatically controlled from a stringline; vertical alignment was automatically controlled from the surface of the leveling course.

\section{Runway Layout}

7. The old runway was $150 \mathrm{ft}$ wide with 25 -ft-square slabs. The overlay was $146 \mathrm{ft}$ wide, but the joints of the overlay were staggered so that the joints in the old pavement coincided with the center of the slabs in the overlay. This arrangement resulted in five $25-\mathrm{ft}$ lanes with 10.5 - $\mathrm{ft}$ lanes on either edge. In the overlay, transverse joints were spaced at $25 \mathrm{ft}$, which resulted in 25 -by 25 - $\mathrm{ft}$ slabs in the five interior lanes and 25 - by 10.5 -ft slabs in the two outer lanes. The runway had a 1 percent cross slope.

\section{Construction Sequence}

8. The center lane was slipformed with vertical faces. Holes for the dowels were drilled and the dowel bars secured with epoxy grout. The two outer $25-\mathrm{ft}$ lanes were then slipformed with metal keyways and tie bars. After the concrete had hardened, the tie bars were straightened. The two 25 -ft lanes, on either side of the center lane, and the outer 10.5 - $\mathrm{ft}$ lanes were poured using conventional procedures. All transverse contraction joints were sawed. 


\section{Construction Procedure}

9. Transverse dowels were preplaced on chairs and pinned to the leveling course. Concrete was dumped directly on the dowels to prevent movement; the remainder of the concrete was placed with a belt-type spreader. Wire mesh was placed on top of the fresh concrete and tamped into place by beaters mounted on the front of the paver. The paver had an auger for removing excess concrete, spud vibrators for consolidating the concrete, tampers for pushing the aggregate from the surface, a forming screed for shaping the cross section, and an oscillating belt for finishing the surface. The paver was followed by a unit carrying a pipe float and burlap drag for final finishing and surface texturing and by another unit with a transverse brush and curing compound applicator for final surface texturing and application of curing compound.

\section{Joints and Load Transfer Devices}

10. Dowel bars in all transverse joints were placed during forming; the joints were sawed after the concrete had hardened. Dowels in the longitudinal joints along both edges of the center lane were placed by drilling and epoxying after the concrete had hardened. Keyways formed in the two outer 25 -ft lanes had 4-in.-thick upper and lower lips with a 3-1/2- by 1-1/4-in. metal keyway. Tie bars 5/8 in. in diameter by $24 \mathrm{in}$. long and spaced 24 in. center-to-center were slipped in with the keyways.

\section{Grade and Surface Smoothness Specifications}

11. Grade and smoothness requirements were established by FAA specifications. Smoothness requirements set a maximum deviation of $1 / 4 \mathrm{in}$. from a $16-\mathrm{ft}$ straightedge in any direction. For a vertical alignment, a maximum deviation of $1 / 4 \mathrm{in}$. from an established grade was allowed, and for a horizontal alignment a maximum $0.10-\mathrm{ft}$ deviation was allowed from an established line. In addition to the above-mentioned horizontal alignment requirement, no edge could have a deviation of more than $1 / 4$ in. from a $16-\mathrm{ft}$ straightedge.

12. A summation of measurements taken with a $16-\mathrm{ft}$ straightedge at the time of the inspection follows:

\section{TRANSVERSE MEASUREMENTS}

\section{Slipform Lane, Interior}

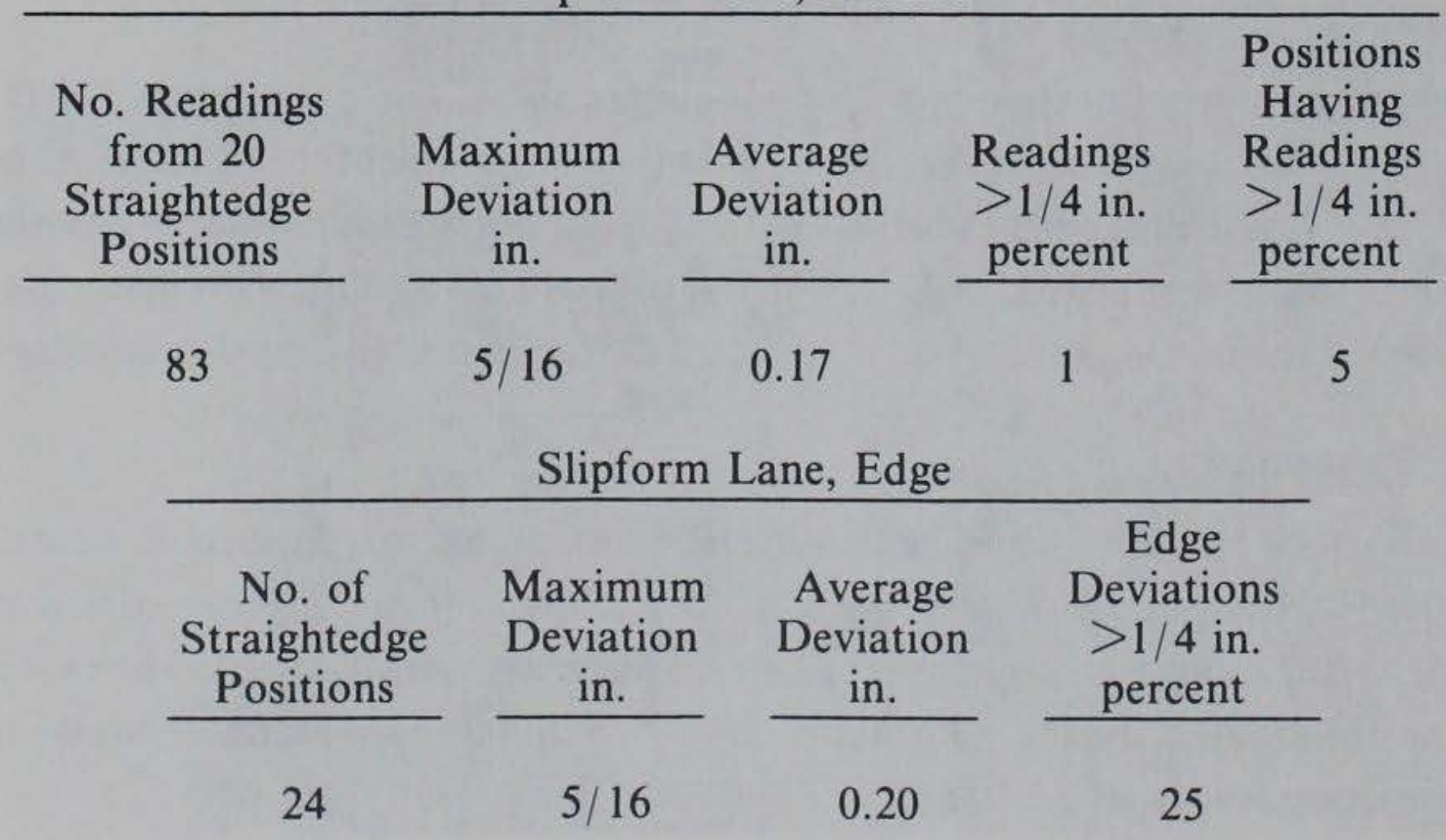




\begin{tabular}{|c|c|c|c|c|c|c|}
\hline $\begin{array}{c}\text { No. of Readings } \\
\text { from } 12 \\
\text { Straightedge } \\
\text { Positions } \\
\end{array}$ & $\begin{array}{c}\text { Maximum } \\
\text { Devia- } \\
\text { tion } \\
\text { in. } \\
\end{array}$ & $\begin{array}{l}\text { Average } \\
\text { Devia- } \\
\text { tion } \\
\text { in. } \\
\end{array}$ & $\begin{array}{l}\text { Readings } \\
>1 / 8 \text { in. } \\
\text { percent }\end{array}$ & $\begin{array}{c}\text { Positions } \\
\text { Having } \\
\text { Readings } \\
>1 / 8 \text { in. } \\
\text { percent }\end{array}$ & $\begin{array}{l}\text { Readings } \\
>1 / 4 \mathrm{in} . \\
\text { percent }\end{array}$ & $\begin{array}{c}\text { Positions } \\
\text { Having } \\
\text { Readings } \\
>1 / 4 \mathrm{in} . \\
\text { percent }\end{array}$ \\
\hline 25 & $1 / 4$ & 0.12 & 24 & 33 & 0 & 0 \\
\hline
\end{tabular}

13. The following comments are based on the observations noted at the time of the runway construction.

a. Inspection and supervision of the job were very good. The contractor frequently ran slump tests and tests for entrained air to ensure uniformity of the concrete. Two inspectors were present at all times to check thickness, grade, horizontal alignment, and edge slump.

b. Inspectors indicated that after the first day and a half, the contractor had no problems meeting grade and smoothness specifications.

c. Very little hand finishing was needed after the section was formed.

$d$. The contractor tried to compensate for the edge slump by thickening the edges slightly. The consensus was that after the edge had slumped, the pipe float would smooth out the section. It appeared that after the edge slumped, there was a small hump about 3 to 6 in. from the edge that the pipe float did not eliminate. However, the smoothness appeared to still be within the allowable values.

e. Inspectors and the contractor indicated they had less problem with edge slump on the keyed edges than they did on the vertical edges.

$f$. The general appearance and quality of the workmanship of the finished pavement were very good.

\section{PROJECT 2}

14. On 19-20 August 1971, the construction of a 24-ft-wide highway pavement was observed. Details of the highway pavement are given in the following paragraphs.

\section{Pavement Description}

15. The pavement was $24 \mathrm{ft}$ wide, 7 in. thick, and had continuous reinforcing steel.

\section{Base Course}

16. The base course consisted of 8 in. of crushed limestone which was placed, compacted, and finished with a grader that was automatically controlled from a stringline.

\section{Mix Design}

17. The mix was designed for $564 \mathrm{lb} / \mathrm{yd}^{3}$ of cement with a water to cement ratio of 0.44 . The contractor tried to maintain a slump of approximately 1-3/4 in. and approximately 6 percent entrained air. The aggregate was a crushed limestone with a maximum size of $1-1 / 2$ in. 


\section{Paving Equipment}

18. The paving train consisted of a CMI spreader with a mechanism for lifting the steel and holding it in place while the concrete was being placed, a CMI slipform paver, a pipe float, a burlap drag, a transverse brush, and a curing-compound applicator. Horizontal alignment was automatically controlled from a stringline; vertical alignment was automatically controlled from the surface of the base course.

\section{Pavement Layout}

19. The 24-ft-wide pavement consisted of two 12 -ft traffic lanes, separated by a longitudinal contraction joint along the center line.

\section{Construction Sequence}

20. Steel mats were preplaced on the subgrade in front of the spreader. The mats were tied, lifted, and held in place by a series of rollers on the spreader while the concrete was placed. An auger removed the excess concrete while spud vibrators consolidated the concrete. Two screeds oscillating transversely formed the cross section and a pan float finished the surface. The paver was followed by a unit carrying a pipe float and burlap drag for final finishing and surfacing texturing and by another unit with a transverse brush and curing compound applicator for final surface and application of curing compound.

\section{Joints and Load Transfer Devices}

21. The only joint in the pavement was a sawed longitudinal contraction joint along the center line of the pavement.

\section{Grade and Surface Smoothness Specifications}

22. A maximum deviation of $1 / 8 \mathrm{in}$. from a $10-\mathrm{ft}$ straightedge was allowed in a longitudinal direction. No requirements were established for transverse smoothness, but $3 / 8$ in. for edge slump was allowed.

23. A summation of edge slump measurements made with a 4-ft straightedge is shown below:

\begin{tabular}{|c|c|c|c|c|}
\hline $\begin{array}{c}\text { No. } \\
\text { Readings }\end{array}$ & $\begin{array}{c}\text { Maximum } \\
\text { Deviation } \\
\text { in. }\end{array}$ & $\begin{array}{c}\text { Average } \\
\text { Deviation } \\
\text { in. }\end{array}$ & $\begin{array}{l}\text { Readings } \\
>1 / 4 \text { in. } \\
\text { percent }\end{array}$ & $\begin{array}{l}\text { Readings } \\
>3 / 8 \text { in. } \\
\text { percent }\end{array}$ \\
\hline 110 & $3 / 4$ & 0.18 & 13 & 2 \\
\hline
\end{tabular}

24. The following comments are formed from personal observations of the highway pavement construction.

a. This was the contractor's first experience with slipform paving. The work was extremely poor initially, but as the equipment operators became familiar with the equipment, the quality of the work improved.

$b$. The inspection appeared to be poor. The only inspection of the finished surface that was observed were straightedge measurements taken longitudinally along the hardened concrete. 
c. At one time, the paver treads started digging into the subbase. The paver was going up a fairly steep grade and was carrying an excess of concrete in front of the auger. The steep grade and excess concrete apparently overloaded the paver.

d. Several problems with the placing of the steel were observed. The steel became entangled in the spreader, causing it to bow up behind the spreader. The steel had to be cut and pushed back into place. At one time, several bars were protruding through the surface of the finished concrete. These bars, probably bent in the spreader, had to be cut out with a torch.

$e$. The general appearance and quality of the workmanship of the finished pavement were poor. When an edge slumped excessively and required stabilization with wooden forms, very little care was taken to see that a smooth edge was obtained.

\section{PROJECT 3}

25. On 18-19 October 1971, the construction of a 150 -ft-wide overlay of an existing runway was observed. Details of the overlay construction are given in the following paragraphs.

\section{Overlay Description}

26. The overlay is $150 \mathrm{ft}$ wide with a variable thickness which averaged about $12 \mathrm{in}$. at the center.

\section{Existing Pavement}

27. The pavement being overlaid was a 9 -in. thick PCC pavement, $150 \mathrm{ft}$ wide. Joints were spaced to give 12-1/2-ft-square slabs. The only preparation given the surface of the old pavement was a cleaning with a broom and wetting just ahead of the paver.

\section{Mix Design}

28. The mix was designed for $564 \mathrm{lb} / \mathrm{yd}^{3}$ of cement. The aggregate was crushed limestone with a maximum size of 2-1/2 in. The allowable slump of the concrete was $1 / 2$ to $1-1 / 2 \mathrm{in}$. The contractor tried to maintain a slump of approximately $1 \mathrm{in}$. The air-entraining agent used resulted in an entrained air content of approximately 6 percent.

\section{Paving and Batch Equipment}

29. A fully automatic Rex batch plant with an 8-1/2-cu-yd tilting drum capacity was used to batch 8 -cu-yd batches. The mix time specified was $80 \mathrm{sec}$ after charging was complete. The paving train consisted of a CMI slipform paver, a burlap drag, and a curing-compound applicator. During observations, horizontal alignment was automatically controlled and referenced to the edge of a previously poured slab; vertical alignment was automatically controlled and referenced to a stringline on one side and to the top of the previously poured slab on the other side.

\section{Runway Layout}

30. The overlay was $150 \mathrm{ft}$ wide with $12-1 / 2-\mathrm{ft}$-square slabs arranged so that the joints matched the joints in the old pavement.

\section{Construction Sequence}

31. The overlay was constructed by paving six 25 -ft-wide lanes. The two outer lanes, constructed first, had keyways on the inside edges formed with metal strips. Bent tie bars were inserted through the 
key and straightened after the concrete had hardened. Tie bars were also inserted in the center of the $25-$ $\mathrm{ft}$ lane while the concrete was plastic. The tie bars tied the outer three $12-1 / 2-\mathrm{ft}$ slabs together. The two lanes adjacent to the outside lanes were then poured with keys formed on the inside edges. One of the center lanes was then poured with a key formed at the center line. The last center lane completed the runway. All transverse and logitudinal contraction joints were sawed.

\section{Construction Procedure}

32. Concrete was dumped directly on the old pavement in front of the paver from end-dump trucks and spread by an auger in front of the strike-off; this procedure roughly formed the section. Spud vibrators consolidated the concrete and two transversely oscillating screeds formed the cross section. A pan float finished the surface and extruded the male keyways. A burlap drag was attached to the paver for surface finishing. The paver was followed by the finishers who hand finished the surface. Behind the hand finishers was a burlap and curing-compound applicator unit.

\section{Grade and Surface Smoothness Specifications}

33. Grade and smoothness requirements were established by FAA specifications. Smoothness requirements set a maximum of 1/4-in. deviation from a 16-ft straightedge in any direction. For a vertical alignment, a maximum of 1/4-in. deviation from an established grade was allowed; for a horizontal alignment, a maximum 0.10 -ft deviation was allowed from an established line. In addition to the above-mentioned horizontal alignment requirement, no edge could have a deviation of more than $1 / 4$ in. from a $16-\mathrm{ft}$ straightedge.

34. Smoothness measurements were made at eleven transverse locations, $10 \mathrm{ft}$ apart, on a $100-\mathrm{ft}$ section of one of the slipformed lanes using a 12-ft straightedge. A summation of these measurements is as follows:

Slipform Lane, Interior

\begin{tabular}{|c|c|c|c|c|}
\hline $\begin{array}{l}\text { No. Readings } \\
\text { from } 33 \\
\text { Straightedge } \\
\text { Positions } \\
\end{array}$ & $\begin{array}{c}\text { Maximum } \\
\text { Deviation } \\
\text { in. } \\
\end{array}$ & $\begin{array}{c}\text { Average } \\
\text { Deviation } \\
\text { in. } \\
\end{array}$ & $\begin{array}{l}\text { Readings } \\
>1 / 4 \text { in. } \\
\text { percent }\end{array}$ & $\begin{array}{c}\text { Positions } \\
\text { Having } \\
\text { Readings } \\
>1 / 4 \text { in. } \\
\text { percent } \\
\end{array}$ \\
\hline 134 & $1 / 2$ & 0.18 & 19.5 & 36 \\
\hline
\end{tabular}

Slipform Lane, Edge

\begin{tabular}{|c|c|c|c|}
\hline $\begin{array}{c}\text { No. of } \\
\text { Straightedge } \\
\text { Positions }\end{array}$ & $\begin{array}{c}\text { Maximum } \\
\text { Deviation } \\
\text { in. } \\
\end{array}$ & $\begin{array}{c}\text { Average } \\
\text { Deviation } \\
\text { in. } \\
\end{array}$ & $\begin{array}{c}\text { Edge } \\
\text { Deviations } \\
>1 / 4 \text { in. } \\
\text { percent }\end{array}$ \\
\hline 20 & $9 / 16$ & 0.10 & 10 \\
\hline
\end{tabular}

35. Longitudinal measurements and transverse measurements were made in the same section of the runway. A summation of those measurements is shown below: 


\begin{tabular}{|c|c|c|c|c|c|c|}
\hline $\begin{array}{l}\text { No. of Readings } \\
\text { from } 60 \\
\text { Straightedge } \\
\text { Positions } \\
\end{array}$ & $\begin{array}{c}\text { Maximum } \\
\text { Devia- } \\
\text { tion } \\
\text { in. } \\
\end{array}$ & $\begin{array}{l}\text { Average } \\
\text { Devia- } \\
\text { tion } \\
\text { in. } \\
\end{array}$ & $\begin{array}{l}\text { Readings } \\
>1 / 8 \text { in. } \\
\text { percent }\end{array}$ & $\begin{array}{c}\text { Positions } \\
\text { Having } \\
\text { Readings } \\
>1 / 8 \mathrm{in} . \\
\text { percent } \\
\end{array}$ & $\begin{array}{l}\text { Readings } \\
>1 / 4 \text { in. } \\
\text { percent }\end{array}$ & $\begin{array}{c}\text { Positions } \\
\text { Having } \\
\text { Readings } \\
>1 / 4 \text { in. } \\
\text { percent }\end{array}$ \\
\hline 83 & $3 / 8$ & 0.17 & 61 & 48 & 2 & 3 \\
\hline
\end{tabular}

36. The following comments are based on visual observations made during this inspection.

a. No effort was made to compensate for edge slump by upsetting the edges. As the edge was formed, some slumping occurred, but the finishers were able to eliminate almost all evidence of edge slump by carefully finishing the edges. Large amounts of water were added to the surface thereby producing large amounts of grout or slurry. The slurry was worked across the surface to the edge where the excess was removed. Because of the large amount of grout at the surface, scaling may become a problem after the surface is subjected to traffic and freeze-thaw cycles.

b. Inspection of the finished pavement appeared limited.

c. The keys appeared rather ragged. Honeycombs or voids frequently appeared in the 1-by 2in. key. Large aggregate (2-1/2-in. maximum) was used and possibly caused the voids in the key.

d. The direct placement of the overlay on the surface of the oid pavement caused problems. Due to the roughness of the old pavement, the thickness of the overlay was varied constantly to create a smooth finished surface. The contractor, the engineers, and the paver manufacturer representative agreed that a much better pavement could have been obtained -if a leveling course had been used.

\section{PROJECT 4}

37. On 29-30 November 1971, construction of a concrete apron with a slipform paver was observed. Details of the apron construction are given in the following paragraphs.

\section{Pavement Description}

38. The apron is constructed around a terminal building to provide parking space for loading and refueling. The 16 -in.-thick pavement was formed in 25 -ft-wide pours.

\section{Base Course}

39. The base course consisted of 6 in. of cement-treated crushed syenite with fines for binder. The base course was placed on a 7 -in. layer of soil cement.

\section{Mix Design}

40. The mix was designed for $540 \mathrm{lb} / \mathrm{yd}^{3}$ of cement. An air-entraining agent was added resulting in an entrained air content of about 6 percent. The contractor tried to maintain a slump of approximately $3 / 4$ in. The crushed syenite aggregate had a maximum size of 1-1/2 in.

\section{Paving and Batch Equipment}

41. An automatically controlled batch plant was used to batch 8-cu-yd batches. The ingredients were discharged into 8-cu-yd truck mixers for mixing and transfer to the paving site. The paving train 
consisted of a CMI slipform paver and a self-propelled pipe float with a burlap drag attached. For the slipformed lanes, horizontal and vertical alignment were automatically controlled and referenced to a stringline. For the fill-in lanes, horizontal alignment was automatically controlled and referenced to the edge of a previously poured lane; vertical alignment was automatically controlled and referenced to the surface of the previously poured lanes.

\section{Construction Sequence}

42. The outer lanes and all lanes adjacent to drainage structures and terminal building were placed using forms. The forms produced a keyway. Tie bars tied the outer lanes to the adjacent lanes. Every other interior lane was placed with the CMI slipform paver which formed a key. Dimensions of the key are given in Figure A1. Fill-in lanes were placed using the CMI slipform paver with the sideforms removed. Transverse contraction joints were sawed in each lane, resulting in 25 -ft-square slabs. The transverse contraction joints coincided in all lanes.

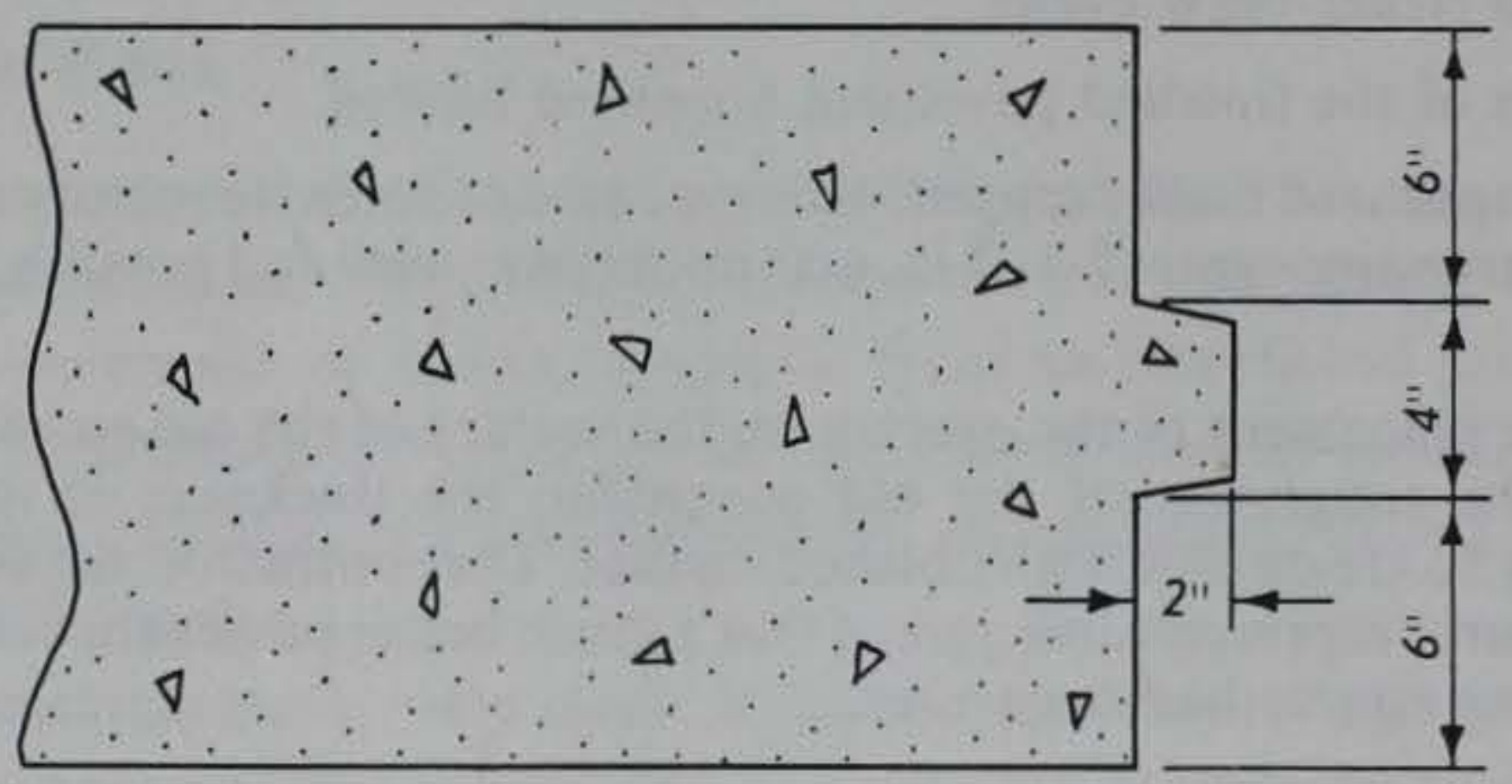

Figure A1. Key formed with CMI paver

\section{Construction Procedure}

43. Concrete was discharged from the truck mixers directly on the base in front of the paver and spread by an auger in front of the strike-off; this procedure roughly formed the cross section. Spud vibrators consolidated the concrete and two transversely oscillating screeds and a pan float formed the cross section. Final surface finishing was accomplished by hand finishers and a pipe float. A burlap drag was used for surface texturing.

\section{Grade and Surface}

\section{Smoothness Specifications}

44. Grade and smoothness requirements were established by FAA specifications. Smoothness requirements set a maximum of 1/4-in. deviation from a 16-ft straightedge in any direction. For a vertical alignment, a maximum of 1/4-in. deviation from an established grade was allowed; for a horizontal alignment, a maximum 0.10 -ft deviation was allowed from an established line. In addition to the above horizontal alignment requirement, no edge could have a deviation of more than $1 / 4$ in. from a 16-ft straightedge.

45. A summation of longitudinal, transverse, and edge measurements taken with a 12 - $\mathrm{ft}$ straightedge is shown below: 


\section{TRANSVERSE MEASUREMENTS}

Placement of Straightedge

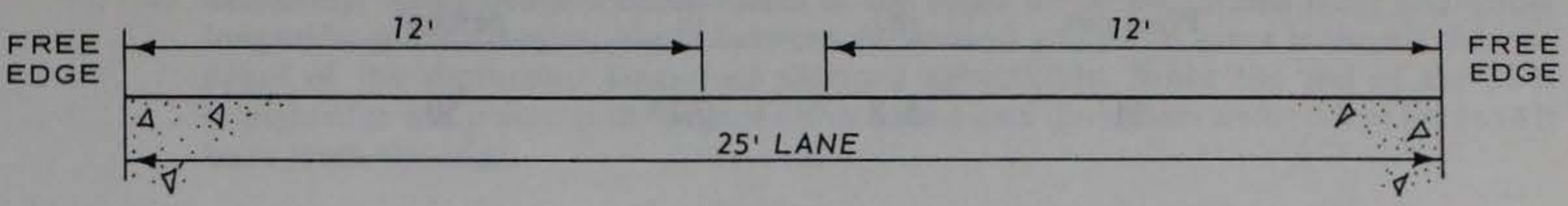

Slipform Lane, Interior

\begin{tabular}{|c|c|c|c|c|}
\hline $\begin{array}{l}\text { No. Readings } \\
\text { from } 22\end{array}$ & Maximum & Average & Readings & $\begin{array}{l}\text { Positions } \\
\text { Having } \\
\text { Readings }\end{array}$ \\
\hline $\begin{array}{l}\text { Straightedge } \\
\text { Positions }\end{array}$ & $\begin{array}{l}\text { Deviation } \\
\text { in. }\end{array}$ & $\begin{array}{l}\text { Deviation } \\
\text { in. }\end{array}$ & $\begin{array}{l}>1 / 4 \mathrm{in} . \\
\text { percent }\end{array}$ & $\begin{array}{l}>1 / 4 \mathrm{in} . \\
\text { percent }\end{array}$ \\
\hline 29 & $7 / 16$ & 0.17 & 7 & 9 \\
\hline
\end{tabular}

Slipform Lane, Edge

$\begin{array}{ccccc}\begin{array}{c}\text { No. of } \\ \text { Straightedge } \\ \text { Positions }\end{array} & \begin{array}{c}\text { Maximum } \\ \text { Deviation } \\ \text { in. }\end{array} & \begin{array}{c}\text { Average } \\ \text { Deviation } \\ \text { in. }\end{array} & & \begin{array}{c}\text { Edge } \\ \text { Deviations } \\ >1 / 4 \text { in. } \\ \text { percent }\end{array} \\ & 3 / 4 & & 0.47 & 82\end{array}$

Placement of Straightedge

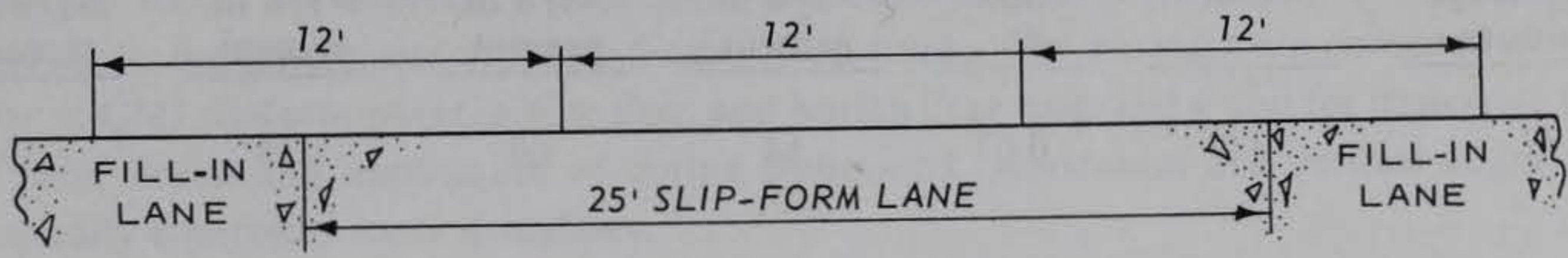

Slipform Lane, Interior

\begin{tabular}{|c|c|c|c|c|}
\hline $\begin{array}{l}\text { No. Readings } \\
\text { from } 30 \\
\text { Straightedge } \\
\text { Positions } \\
\end{array}$ & $\begin{array}{c}\text { Maximum } \\
\text { Deviation } \\
\text { in. } \\
\end{array}$ & $\begin{array}{c}\text { Average } \\
\text { Deviation } \\
\text { in. } \\
\end{array}$ & $\begin{array}{c}\text { Readings } \\
>1 / 4 \text { in. } \\
\text { percent }\end{array}$ & $\begin{array}{c}\text { Positions } \\
\text { Having } \\
\text { Readings } \\
>1 / 4 \mathrm{in} . \\
\text { percent }\end{array}$ \\
\hline 14 & $3 / 8$ & 0.16 & 7 & 3 \\
\hline
\end{tabular}




$\begin{array}{ccccc}\begin{array}{c}\text { No. of } \\ \text { Straightedge } \\ \text { Positions }\end{array} & \begin{array}{c}\text { Maximum } \\ \text { Deviation } \\ \text { in. }\end{array} & \begin{array}{c}\text { Average } \\ \text { Deviation } \\ \text { in. }\end{array} & & \begin{array}{c}\text { Edge } \\ \text { Deviations } \\ >1 / 4 \text { in. } \\ \text { percent }\end{array} \\ & 5 / 8 & & 0.27 & 50\end{array}$

Fill-In Lane, Edge

\begin{tabular}{|c|c|c|c|c|}
\hline $\begin{array}{l}\text { No. Readings } \\
\text { from } 24 \\
\text { Straightedge } \\
\text { Positions }\end{array}$ & $\begin{array}{l}\text { Maximum } \\
\text { Deviation } \\
\text { in. } \\
\end{array}$ & $\begin{array}{c}\text { Average } \\
\text { Deviation } \\
\text { in. }\end{array}$ & $\begin{array}{l}\text { Readings } \\
>1 / 4 \text { in. } \\
\text { percent }\end{array}$ & $\begin{array}{c}\text { Positions } \\
\text { Having } \\
\text { Readings } \\
>1 / 4 \text { in. } \\
\text { percent }\end{array}$ \\
\hline 13 & $1 / 4$ & 0.14 & 0 & 0 \\
\hline
\end{tabular}

Fill-In Lane, Edge

\begin{tabular}{|c|c|c|c|}
\hline $\begin{array}{c}\text { No. of } \\
\text { Straightedge } \\
\text { Positions } \\
\end{array}$ & $\begin{array}{l}\text { Maximum } \\
\text { Deviation } \\
\text { in. }\end{array}$ & $\begin{array}{c}\text { Average } \\
\text { Deviation } \\
\text { in. } \\
\end{array}$ & $\begin{array}{c}\text { Edge } \\
\text { Deviations } \\
>1 / 4 \text { in. } \\
\text { percent }\end{array}$ \\
\hline 24 & $5 / 8$ & 0.24 & 41 \\
\hline
\end{tabular}

LONGITUDINAL MEASUREMENTS

\begin{tabular}{|c|c|c|c|c|c|c|}
\hline $\begin{array}{l}\text { No. of Readings } \\
\text { from } 16 \\
\text { Straightedge } \\
\text { Positions } \\
\end{array}$ & $\begin{array}{c}\text { Maximum } \\
\text { Devia- } \\
\text { tion } \\
\text { in. } \\
\end{array}$ & $\begin{array}{l}\text { Average } \\
\text { Devia- } \\
\text { tion } \\
\text { in. } \\
\end{array}$ & $\begin{array}{l}\text { Readings } \\
>1 / 8 \text { in. } \\
\text { percent }\end{array}$ & $\begin{array}{c}\text { Positions } \\
\text { Having } \\
\text { Readings } \\
>1 / 8 \text { in. } \\
\text { percent } \\
\end{array}$ & $\begin{array}{l}\text { Readings } \\
>1 / 4 \mathrm{in} . \\
\text { percent }\end{array}$ & $\begin{array}{c}\text { Positions } \\
\text { Having } \\
\text { Readings } \\
>1 / 4 \text { in. } \\
\text { percent }\end{array}$ \\
\hline 17 & $3 / 8$ & 0.07 & 64 & 69 & 18 & 19 \\
\hline
\end{tabular}

46. The following comments are based on the observations of the apron construction during this inspection:

a. The edges were upset by up to 1 in. to compensate for edge slump.

b. Most of the keys formed during the slipform operation looked very good. However, some honeycombing was noted along the keys.

c. Horizontal alignment along the edges was adequate. Insignificant waviness was observed. In some locations along the edges, a large amount of grout had been deposited from surface finishing operations. 
d. During the construction of the fill-in lanes, the transversely oscillating screeds of the CMI paver did not cause any noticeable scour of the lanes on either side. On one job, the aggregate under oscillating screeds had caused a great deal of scouring of the existing lanes. This was apparently caused by an excessive overlap of the screeds over the existing lanes.

$e$. Transverse straightedge measurements at the edges of the slipformed lanes and across longitudinal construction joints between slipformed and fill-in lanes indicated that the edges of the slipformed lanes had slumped appreciably. When the end of the $12-\mathrm{ft}$ straightedge was placed at the edge of a slipformed lane, deviations were evident for 3 to $4 \mathrm{ft}$ back from the edge.

\section{PROJECT 5}

47. On 10-12 January 1972, the construction of a new PCC runway and the overlay of a taxiway were observed. Details of the runway and taxiway overlay construction are given in the following paragraphs.

\section{Pavement Description}

48. The 16-in.-thick pavement in the runway was formed in 25 -ft-wide lanes. The 6 -in. overlay on the taxiway was formed in 25 -ft-wide lanes.

\section{Base Course}

49. The base course for the new runway consisted of 6 in. of soil cement. The old pavement on the taxiway was $12 \mathrm{in}$. thick and was in good condition. The overlay, placed in anticipation of increased aircraft loads and traffic volume, was bonded to the old pavement with a $1 / 8$-in.-thick cement grout.

\section{Mix Design}

50. The mix was designed for $520 \mathrm{lb} / \mathrm{yd}^{3}$ of cement. The water-cement ratio varied by the contractor approached a slump of approximately $3 / 4 \mathrm{in}$. Specifications limited the slump to $1 / 2$ to 1 $1 / 2$ in. The aggregate was a crushed limestone of poor quality with a maximum size of $1-1 / 2$ in.

\section{Paving and Batching Equipment}

51. A fully automatic Rex twin-drum batch plant was used to batch and mix 9-cu-yd batches. Mix time was $20 \mathrm{sec}$ in the stationary horizontal drum and $50 \mathrm{sec}$ in the tilting drum. Concrete was transported to the paving site in 9-cu-yd side dump trucks. The paving train consisted of a Maxon spreader, a CMI slipform paver, a pipe float and burlap drag unit, and a unit for transverse texturing with a wire brush and application of curing compound. Horizontal and vertical alignment were automatically controlled from stringlines.

\section{Pavement Layout}

52. The old taxiway was $75 \mathrm{ft}$ wide with $16-\mathrm{ft}-8$-in. by $12-\mathrm{ft}-6$-in. slabs. The overlay was constructed so that the joints in the overlay matched the joints in the old pavement. The new runway is $150 \mathrm{ft}$ wide with $16-\mathrm{ft}-8$-in. by 12 -ft-6-in. slabs.

\section{Construction Sequence}

53. The 75 -ft-wide overlay was constructed by paving three 25 -ft-wide lanes; the two outer lanes were slipformed first while the center lane was formed by filling in between the two outer lanes. The 150- 
ft-wide runway was constructed of six 25 -ft-wide lanes by slipforming one of the center lanes and paving all other lanes with one edge of the lane abutting a previously poured lane and with one edge free. All transverse and longitudinal contraction joints were sawed.

\section{Construction Procedure}

54. Concrete was dumped into the Maxon spreader from the side-dump trucks and spread over the entire width of the pour. An auger for spreading concrete in front of the strike-off roughly formed the section. Spud vibrators consolidated the concrete and two transversely oscillating screeds formed the cross section. A pan float finished the surface and the male keyways were extruded by side forms on the paver. Final surface finishing was accomplished by a pipe float and hand finishers. The surface was textured by transverse brushing with a wire comb. Construction was completed with the application of a curing compound.

\section{Load Transfer Devices}

55. In the runway and taxiway, dowels were provided at the two transverse joints on either side of crossing runways and taxiways. Dowels were also provided at all transverse expansion and construction joints. No load transfer devices were used in longitudinal joints in the overlay of the taxiway. In the runway, all longitudinal construction joints were keyed. Keys were formed with dimensions shown in Figure A2. Deformed tie bars were installed along all longitudinal contraction joints on the runway. These tie bars were placed while the concrete was plastic by pushing them into place along the center line of the 25 -ft-wide pours.

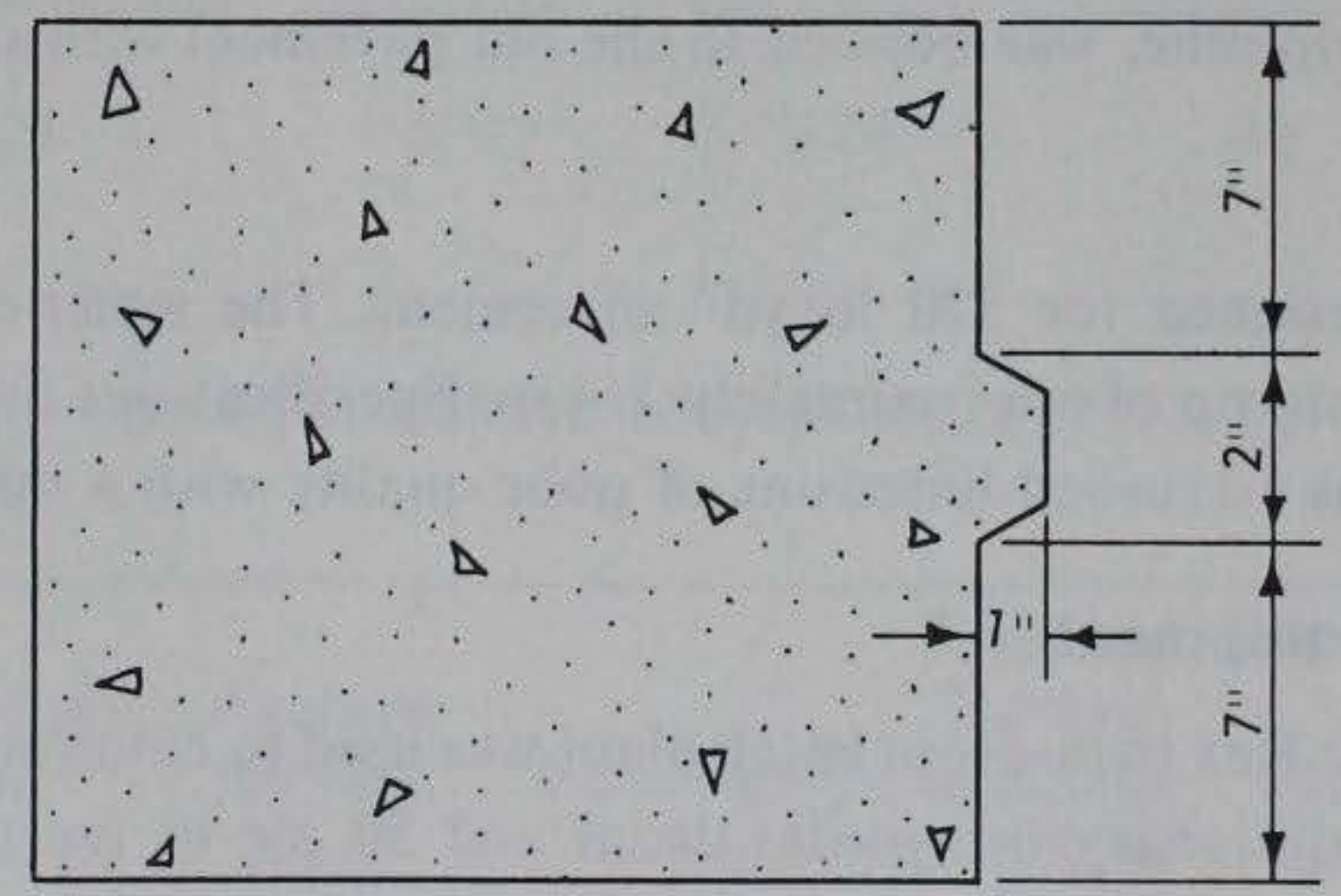

Figure A2. Key formed with CMI paver

\section{Grade and Surface \\ Smoothness Specifications}

56. Grade and smoothness requirements were established by FAA specifications. Smoothness requirements set a maximum of 1/4-in. deviation from a 16-ft straightedge in any direction. For a vertical alignment, a maximum 1/4-in. deviation from an established grade was allowed; for a horizontal alignment, a maximum 0.10 -ft deviation was allowed from an established line. In addition to the above-mentioned horizontal alignment requirement, no edge could have a deviation of more than $1 / 4$ in. from a $16-\mathrm{ft}$ straightedge.

57. Smoothness measurements were taken across longitudinal construction joints with a $4-\mathrm{ft}$ 
straightedge on both the runway and the taxiway. A summation of the measurements follows:

\section{RUNWAY PAVEMENT}

\begin{tabular}{|c|c|c|c|}
\hline \multicolumn{4}{|c|}{ Slipform Lane, Edge } \\
\hline $\begin{array}{c}\text { No. } \\
\text { Readings }\end{array}$ & $\begin{array}{l}\text { Maximum } \\
\text { Deviation } \\
\text { in. }\end{array}$ & $\begin{array}{c}\text { Average } \\
\text { Deviation } \\
\text { in. } \\
\end{array}$ & $\begin{array}{c}\text { Edge } \\
\text { Deviations } \\
>1 / 4 \text { in. } \\
\text { percent } \\
\end{array}$ \\
\hline 21 & $3 / 4$ & 0.40 & 71 \\
\hline
\end{tabular}

Fill-In Lane, Edge

\begin{tabular}{ccccc}
\hline $\begin{array}{c}\text { No. } \\
\text { Readings }\end{array}$ & $\begin{array}{c}\text { Maximum } \\
\text { Deviation } \\
\text { in. }\end{array}$ & $\begin{array}{c}\text { Average } \\
\text { Deviation } \\
\text { in. }\end{array}$ & $\begin{array}{c}\text { Edge } \\
\text { Deviations } \\
>1 / 4 \text { in. } \\
\text { percent }\end{array}$ \\
\cline { 1 - 1 } & $1 / 2$ & & 0.32 & 57
\end{tabular}

\section{TAXIWAY PAVEMENT}

Slipform Lane, Edge

\begin{tabular}{|c|c|c|c|}
\hline $\begin{array}{c}\text { No. } \\
\text { Readings }\end{array}$ & $\begin{array}{c}\text { Maximum } \\
\text { Deviation } \\
\text { in. } \\
\end{array}$ & $\begin{array}{l}\text { Average } \\
\text { Deviation } \\
\text { in. } \\
\end{array}$ & $\begin{array}{c}\text { Edge } \\
\text { Deviations } \\
>1 / 4 \text { in. } \\
\text { percent } \\
\end{array}$ \\
\hline 15 & $5 / 16$ & 0.18 & 13 \\
\hline \multicolumn{4}{|c|}{ Fill-In Lane, Edge } \\
\hline $\begin{array}{c}\text { No. } \\
\text { Readings }\end{array}$ & $\begin{array}{c}\text { Maximum } \\
\text { Deviation } \\
\text { in. } \\
\end{array}$ & $\begin{array}{c}\text { Average } \\
\text { Deviation } \\
\text { in. } \\
\end{array}$ & $\begin{array}{c}\text { Edge } \\
\text { Deviations } \\
>1 / 4 \text { in. } \\
\text { percent } \\
\end{array}$ \\
\hline 15 & $5 / 16$ & 0.10 & 6.5 \\
\hline
\end{tabular}

58. The following comments are personal observations of the runway and taxiway construction:

a. The edges were upset about $1 / 2$ in. to compensate for edge slump.

$b$. The keys appeared rather ragged. Honeycombing and sloughing occurred frequently. The poorly formed keys were probably caused by the large aggregate used. The dimensions of the keys were $1 \mathrm{in}$. by $2 \mathrm{in}$. and the maximum size aggregate used was $1-1 / 2 \mathrm{in}$. The large aggregate probably contributed significantly to the poor quality of the keys. Patching with an epoxy grout was attempted.

c. During construction of a 20 -ft-wide fill-in lane on one of the ramps between the runway and taxiway, considerable scour was caused by aggregate trapped under the oscillating 
screeds where they extended over a previously formed lane. This problem had been observed on another job and resulted in a badly scoured surface.

$d$. The transverse brushing with the wire comb resulted in a very uneven surface texture. In areas where the hand finishers had deposited large amounts of grout, e.g. along the edges, the texture was coarse, while in areas of smaller grout concentration the texture was fine. This was caused by the difference in the ability of the teeth to penetrate the surface of the pavement.

\section{PROJECT 6}

59. On 27 March 1972, the construction of the apron around a new terminal building was observed. Details of the apron construction are given in the following paragraphs.

\section{Pavement Description}

60. The pavement was 14 in. thick in the center with 18 -in.-thickened edges. The transition section was $6 \mathrm{ft}$ wide. The pavement was placed in 37-1/2-ft-wide paving lanes.

\section{Base Course}

61. The base consisted of 10 in. of crushed stone base. The crushed stone was minus 1-1/4-in. material with the upper $1 \mathrm{in}$. of the base course containing no particles larger than $5 / 8$ in. The $5 / 8$-in. maximum-aggregate specification facilitated trimming with an automatically controlled fine grader. A RAHCO autograder was used to trim the base material. The transition sections were shaped with the fine grader.

\section{Mix Design}

62. The mix was designed for $520 \mathrm{lb} / \mathrm{yd}^{3}$ of cement with 35 percent fine aggregate (minus No. 4 material) and 65 percent coarse aggregate ( 50 percent minus 1-1/4-in. material and 50 percent minus 3/4-in. material). The aggregate was a natural gravel. The allowable range of slump was $1 / 2$ to $1-1 / 2 \mathrm{in}$. The contractor tried to maintain a slump of about $1 \mathrm{in}$. The allowable range of entrained air was 3 to 5 percent; the contractor tried to hold the level at about 4 percent.

\section{Paving and Batch Equipment}

63. A fully automatic combination Rex-Blaw Knox batch plant was used. Two 8-cu-yd Rex drums with a mix time of approximately $60 \mathrm{sec}$ were used to mix 8-cu-yd batches. The paving train consisted of a Guntert-Zimmerman slipform paver and a self-propelled machine for texturing and application of curing compound. Vertical and horizontal alignment were automatically controlled and referenced to taut wires on either side of the paver.

\section{Construction Sequence}

64. The pavement was constructed in 37-1/2-ft-wide paving lanes. Keyways were formed in slipformed lanes with metal keyway lines and bent tie bars spaced on 18 -in. centers. The tie bars were straightened and the fill-in lanes placed. Transverse contraction joints were sawed.

\section{Construction Procedure}

65. A key-strip machine formed the keyway liner from 24-gage cold rolled sheet metal strip material and punched holes in the liner for insertion of the tie bars. The tie bars were inserted manually 
and held in place with a horizontal rod attached to the side forms of the paver until the concrete was placed. Concrete was dumped directly onto the subgrade from end-dump trucks. The paver had an auger for spreading the concrete, spud vibrators (spaced 18 in. on center) for consolidating the concrete, a conforming screed for forming the cross section, a strike-off paddle for removing excess material, a rotating screed for initial surface finishing, and a pan float for final surface finishing. A burlap drag attached to the paver filled the smaller voids in the surface; hand finishers worked the edges of slabs only. The surface was textured by transverse brushing with a wire comb. Construction was completed with the application of a membrane-curing compound and burlap.

\section{Load Transfer Devices}

66. Longitudinal construction joints were keyed and tied. The keyway portion of the joint was formed during the slipform operation. Metal keyway liners were left in place and became an integral part of the joint. The dimensions of the keyway are shown in Figure A3. In odd-shaped slabs and near areas of direction, change tie bars were placed along the longitudinal contraction joint. These bars were inserted into the plastic concrete with a hydraulic ram located on the front of the paver. The transverse contraction joints at 20,40 , and $60 \mathrm{ft}$ on either side of expansion joints and at change-of-direction locations were doweled. The dowels were placed on wire assemblies and set on the subgrade in front of the paver at the required locations. Concrete was placed on the dowel assemblies with a front-end loader to minimize movement as the paver passed.

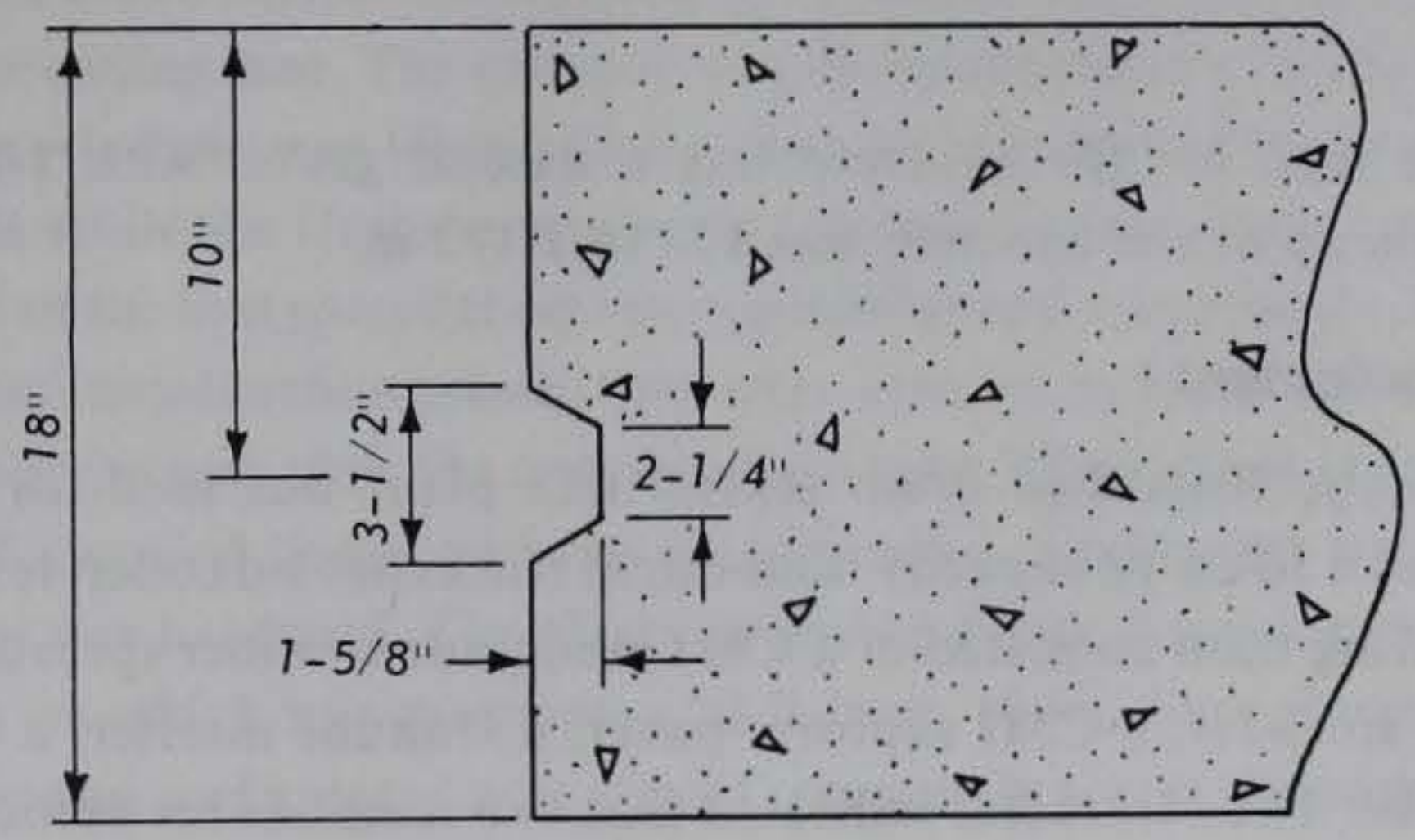

Figure A3. Keyway formed with Guntert-Zimmerman paver

67. The following comments are personal observations of the pavement construction:

a. The keyways formed with the metal liner looked very good. In one instance, the contractor formed the keyway without inserting the bent tie bars. In this instance, the metal liner pulled away from the edge and caused sloughing along the edge. As a result, the contractor inserted some tie bars to hold the liner in place, although they were not required. The tie bars were apparently necessary to hold the liner in place.

$b$. The rod attached to the side form of the paver to hold the tie bars horizontal until concrete was placed worked well.

c. Although no straightedge measurements were made, the edge slump did not appear to be excessive.

d. Hand finishing was confined to the edge of the slabs and the areas near headers. 
$e$. The method of placing the dowels seemed to be unsatisfactory. The assembly used to hold the dowels was made of small wire and did not appear to be very stable. In addition, little care was taken in placing the assemblies. They were simply placed on the subgrade and covered with concrete from a front-end loader. Adjustments in alignment were made with the heel of a workman's boot, thus the resulting alignment was very poor. Heavier assemblies should be used and firmly staked to the subgrade.

\section{PROJECT 7}

68. On 10-11 May 1972, the construction of a concrete runway and taxiway with a slipform paver was observed. Details of the pavement construction are given in the following paragraphs.

\section{Pavement Description}

69. Work on the runway consisted of both overlay and new pavement. The 150 -ft-wide existing concrete runway was overlaid with thicknesses ranging from 9 to 12 in. A 12 -in.-thick 800 -ft extension was added. A new 12-in.-thick 75 -ft-wide taxiway was constructed.

\section{Base Course}

70. A bituminous leveling course, varying in thickness from 2 to $12 \mathrm{in}$., was placed on the old runway pavement. For the new pavement, 6 in. of clay gravel containing 1 -in.-maximum size aggregate was used as a base course. A CMI autograde trimmer was used to trim the surface of the clay gravel base.

\section{Mix Design}

71. The aggregate used for the concrete was a natural gravel with 1-1/2-in.-maximum size aggregate. Allowable slump of the concrete was $1 / 2$ to $1-1 / 2$ in.

\section{Paving and Batch Equipment}

72. A fully automatic Ross dual drum central mix plant was used for batching and mixing concrete. The drums had a 10-cu-yd capacity. End-dump trucks hauled concrete from the batch plant to the paving site. The paving train consisted of a CMI autograde trimmer spreader, a CMI mesh cart, a CMI autograde placer spreader, a CMI slipform paver, a Unitube inserter, a CMI tube float, and a plastic grooving machine. The contractor indicated that two methods for vertical control of the paver had been tried. In the first method, vertical control was referenced to the top of the prepared base or leveling course; the second, and more successful, referenced vertical control to a stringline. Horizontal alignment was referenced to a stringline.

\section{Runway Layout}

73. Slabs in the old pavement were $25 \mathrm{ft}$ square. Slabs in the overlay and runway extension were 45 by $25 \mathrm{ft}$ in the two center lanes and 45 by $12.5 \mathrm{ft}$ in the outer four lanes. In the overlay, no effort was made to match joints in the base pavement.

\section{Taxiway Layout}

74. The taxiway was $75 \mathrm{ft}$ wide with $45-$ by 12.5 - $\mathrm{ft}$ slabs.

\section{Construction Sequence}

75. The runway pavement was constructed by paving six 25 -ft-wide lanes. All longitudinal joints 
were keyed with the two outer lanes on either side of the runway tied with deformed tie bars. The keys were constructed during slipform operations and the tie bars inserted by hand through the key immediately after they were formed. Longitudinal contraction joints were sawed along the center of the four outer lanes resulting in a 12.5 -ft longitudinal joint spacing. No longitudinal joint was sawed in the two center lanes resulting in a 25 - $\mathrm{ft}$ longitudinal-joint spacing.

76. Transverse contraction joints were formed every $45 \mathrm{ft}$ by insertion of a Unitube. Expansion and transverse construction joints were spaced so that the 45 - $\mathrm{ft}$ transverse-joint spacing was maintained. All transverse joints were doweled.

77. The taxiway pavement was constructed by paving three 25 -ft-wide lanes. Both longitudinal construction joints were tied and formed as described above for the runway. All three lanes were sawed longitudinally at midspan to form a 12.5 -ft longitudinal joint spacing. Transverse contraction, expansion, and construction joints were formed as described above which resulted in a 45 -ft transverse joint spacing.

\section{Construction Procedure}

78. The pavement was constructed in two lifts. Concrete was dumped directly onto the base from end-dump trucks and spread by a CMI autograde trimmer spreader to form the first lift. Wire mesh mats were removed from the mesh cart and placed on the first lift by hand. The second lift of concrete was placed with a CMI autograde placer spreader. Side-dump trucks operating beside the spreader dumped the concrete onto a belt which carried the concrete to the center of the paving lane where an auger spread it uniformly across the paving lane. The concrete was then consolidated and the cross section formed by a CMI slipform paver. Unitube was vibrated into place directly behind the paver. No confinement was provided for the sides while the Unitube was being inserted. Dowels for transverse contraction joints were preplaced ahead of the first spreader on wire assemblies and staked to the base. Where tie bars were required in longitudinal construction joints, they were inserted by hand directly behind the paver. The bent tie bars were straightened after the concrete hardened. The surface of the pavement was floated with a tube float and required hand finishing accomplished. Transverse grooves were formed in the surface before the concrete hardened. The plastic grooving device was self-propelled and consisted of a self-propelled chassis on which was mounted a 10 -ft-long, 10-in.-diam aluminum tube. The tube had ridges for forming grooves and rotated as it moved transversly across the pavement. Theoretically, the grooves formed were 1/4 in. wide, $1 / 4$ in. deep, and spaced either 1-1/ 2 or 2 in. on center. After grooving, the pavement was sprayed with a curing compound.

\section{Grade and Surface Smoothness Specifications}

79. Grade and smoothness requirements were established by FAA specifications. Smoothness requirements set a maximum of $1 / 4-i n$. deviation from a 16-ft straightedge in any direction. For a vertical alignment, a maximum of 1/4-in. deviation from an established grade was allowed; for a horizontal alignment, a maximum $0.10-\mathrm{ft}$ deviation was allowed from an established line. In addition to the above-mentioned horizontal alignment requirement, no edge could have a deviation of more than $1 / 4$ in. from a $16-\mathrm{ft}$ straightedge.

80. A summation of longitudinal measurements made on the taxiway with a 12 -ft straightedge is shown below: 


\begin{tabular}{|c|c|c|c|c|c|c|}
\hline $\begin{array}{l}\text { No. of Readings } \\
\text { from } 74 \\
\text { Straightedge } \\
\text { Positions }\end{array}$ & $\begin{array}{l}\text { Maximum } \\
\text { Devia- } \\
\text { tion } \\
\text { in. }\end{array}$ & $\begin{array}{l}\text { Average } \\
\text { Devia- } \\
\text { tion } \\
\text { in. }\end{array}$ & $\begin{array}{l}\text { Readings } \\
>1 / 8 \text { in. } \\
\text { percent }\end{array}$ & $\begin{array}{c}\text { Positions } \\
\text { Having } \\
\text { Readings } \\
>1 / 8 \text { in. } \\
\text { percent }\end{array}$ & $\begin{array}{l}\text { Readings } \\
>1 / 4 \mathrm{in} \text {. } \\
\text { percent }\end{array}$ & $\begin{array}{c}\text { Positions } \\
\text { Having } \\
\text { Readings } \\
>1 / 4 \text { in. } \\
\text { percent }\end{array}$ \\
\hline 188 & $5 / 16$ & 0.12 & 24 & 60 & 1 & 3 \\
\hline
\end{tabular}

81. The following are personal observations of the pavement construction:

a. The insertion of the bent tie bars through the key caused sloughing and slumping of the key. The contractor also stated that the insertion of the tie bars caused some distortion of the surface which was corrected by required hand finishing. Inspection of the tie bars revealed that about half of them could be rotated by hand. However, the contractor indicated that pull tests had shown that adequate bond was obtained. He indicated that even loose bars withstood forces that produced stress near the yield point of the steel.

$b$. The edges and keys looked good except near tie bars.

c. The vibration of the Unitube into place caused some distortion of the surface and free edges. Since no confinement was provided at the free edges, they had to be reshaped by hand. The tube float and hand finishers eliminated the distortion on the surface. The biggest problem with the Unitube was the depth of penetration rather than the disturbance of the free edges. When the Unitube penetrated too deep, spalling would occur after the crack was formed; apparently, the layer of grout deposited over the Unitube during finishing had sufficient strength to shear off the edges of the groove. At these joints where the Unitube was close to the surface, the thin layer of grout would fracture and leave a sharp edge.

d. The success of the plastic grooving is questionable. Surface texture was provided, but whether or not the texture was adequate would be debatable. Theoretically, grooves $1 / 4 \mathrm{in}$. wide and 1/4 in. thick spaced at 1-1/2- or 2-in. centers were to be formed. The average depth of the grooves appeared to be about $1 / 8$ in. rather than $1 / 4$ in. The grooving was very nonuniform, both longitudinally and transversely. In some areas, the grooves would be well formed while in others, there would be very little surface penetration; this is caused by hard and soft areas in the surface of the pavement. Because of the nonuniformity of the surface, it is impossible to apply enough pressure to cause satisfactory grooving of all areas.

\section{PROJECT 8}

82. On 15-16 November 1972, the construction of new apron, taxiway, and runway was observed. Details of the pavement construction are given in the following paragraphs.

\section{Pavement Description}

83. The pavement was 15-, 16-, and 17-in.-thick jointed reinforced concrete pavement. The thickness depended on the type pavement, i.e., apron pavements were $17 \mathrm{in}$. thick. Slabs were 25 by $25 \mathrm{ft}$.

\section{Subbase and Base Course}

84. The subbase was lime-stabilized clay ranging in thickness from 9 to $18 \mathrm{in}$. A cement-treated base was mixed in a pugmill, hauled in bottom-dump trucks, spread, compacted with a vibratory steelwheeled roller, and cut to grade with automatically controlled subgrade planer. The pit-run sandy gravel had a 2-in.-maximum size aggregate which made trimming difficult. 


\section{Mix Design}

85. The mix was designed for $540 \mathrm{lb} / \mathrm{yd}^{3}$ of cement. The concrete slump was maintained at about $1 / 2$ in. Two sizes of crushed limestone were used as aggregate: $3 / 4$ in. to No. 4 and $1-1 / 2$ to $3 / 4$ in.; natural sand was also used. The amount of sand was varied to get a workable mix and a sand content of 34 percent by volume was selected. Entrained air was specified as 4 percent. During hot weather, the contractor resorted to chilled water and nighttime placement to keep the temperature of the concrete within acceptable limits. A water reducing agent was used.

\section{Paving and Batch Equipment}

86. Two fully automatic 12 -cu-yd and one 8-cu-yd Rex dual drum plants were used. The 12-cu-yd capacity plants were used to batch and mix 10-cu-yd batches. Concrete was hauled to the paving site in 20-cu-yd end-dump trucks equipped with ejector systems. Two Guntert and Zimmerman paving trains, which allowed 25 - and 50-ft-wide lanes to be placed were used. A paving train consisted of a paver, a mesh cart, a crane for hauling and placing steel, a second paver equipped with a belt spreader, a combination work bridge and burlap drag unit, and a unit for applying curing compound. Horizontal and vertical alignment were referenced to a taut wire.

\section{Pavement Layout}

87. The two 200 - by 11,400 -ft runways, one 200 - by 9000 -ft crosswind taxiway, and the 100 -ft-wide taxiways were constructed in 50 -ft-wide lanes. Longitudinal contraction joints were sawed in each 50 - $\mathrm{ft}$ wide lane; transverse contraction joints were sawed every $50 \mathrm{ft}$. Longitudinal construction joints were either keyed and tied or doweled; transverse construction and contraction joints were doweled. Apron pavements and transition areas were constructed in 25 -ft-wide lanes. Transverse joints were sawed every $25 \mathrm{ft}$; every other one was doweled with the alternate joints tied with the mats. Longitudinal joints were either doweled or keyed and tied.

\section{Load Transfer Devices}

88. Doweled joints had 1-1/2- by 20 -in. smooth bars. Alternate transverse contraction joints and longitudinal contraction joints depend on aggregate interlock for load transfer. The reinforcing steel extends across the transverse contraction joints creating a tied condition. The 25 - by 50 -ft mats overlap along the longitudinal contraction joints and probably effectively tie the slabs together along this joint. Those longitudinal construction joints, which were not doweled, were keyed and tied with high-strength (60 ksi) deformed tie bars.

\section{Construction Sequence}

89. Taxiways and connectors were constructed with two 50 -ft-wide lanes; runways were constructed in four 50-ft-wide lanes. One of the center lanes was constructed first, the outer lane adjacent to the previously placed center lane placed second, the other center lane third, and finally the outer lane adjacent to the second center lane. Apron pavement was constructed in 25 -ft-wide lanes. Alternate lanes were slipformed first and intermediate lanes filled in between the slipformed lanes. At changes in direction, a clear distance of $25 \mathrm{ft}$ was left between the beginning of the lane and the edge of the abutting lane. These leaveouts and curved sections were filled in by hand.

\section{Construction Procedure}

90. When a paving lane was begun, the steel was staked to the cement-treated base for a distance of 
$75 \mathrm{ft}$ from the header, and the entire thickness placed with the second paver. The remainder of the concrete was placed in two lifts; the steel was placed on top of the first lift. Concrete was dumped directly onto the subgrade in front of the first paver from end-dump trucks. The trucks backed onto the paving lane from the side between the dowel assemblies which were staked to the cement-treated base. This sequence permitted the trucks to back onto the subgrade at all times.

91. The first paver had an auger for spreading the concrete, spud vibrators spaced at $14 \mathrm{in}$. for consolidating the concrete, and a large forming pan for forming the cross section. The first paver placed thicknesses of 10,11 , or 12 in., depending on the total thickness of the pavement. The width of the first lift was about $8 \mathrm{in}$. narrower than the final 25 or $50 \mathrm{ft}$. The 25 - by $50-\mathrm{ft}$ tied mats were lifted from a mesh cart by a crane and positioned on top of the first lift. Two mats were placed side by side across the paving lane. The second paver had three vibrating pans attached to the front which depressed the steel into the first lift.

92. The second lift ( 5 in. thick) was spread in front of the second paver by a series of belts. Concrete was ejected from the end-dump trucks into a paver-mounted hopper. The concrete was fed to a second belt that deposited the concrete directly in front of the spud vibrators (14-in. spacing) on the second paver. In addition to the vibrators, the second paver had a large forming pan, a transversely oscillating screed, a pan float, and a burlap drag. The surface and edges of the pavement were finished manually and a membrane curing compound was sprayed onto the fresh concrete.

93. A very elaborate procedure was used to finish the edges to eliminate the effects of edge slump; this operation, although very efficient, was time-consuming and expensive since it required four men. The procedure called for an on-site mixture of a high slump-high cement content concrete with a $3 / 8$-in. maximum-size aggregate. The sand, aggregate, and cement were preweighed and mixed in a small truckmounted mixer. One man ran the mixer and spread the concrete along the edge; a second troweled the fresh concrete over the surface near the edge (about $1 \mathrm{ft}$ back from the edge) while supporting the vertical face; a third finished the surface and vertical face; and a fourth man formed the edge. The resulting surface should be as durable as the remainder of the surface since the workmen were apparently working the fresh concrete into the surface and the bond should have been good. However, the procedure can only be evaluated after it has been subjected to traffic and weathering. Dowels and tie bars along longitudinal construction joints were placed by drilling holes in the hardened concrete and epoxying the tie bars and dowels. The original plans called for insertion of the tie bars and dowels into the plastic concrete through a slot in the trailing form; this had been abandoned in favor of drilling and grouting.

\section{Grade and Surface Smoothness Specifications}

94. Grade and smoothness requirements were established by FAA specifications.

95. Smoothness measurements, both longitudinal and transverse, were made on Runway 13-31 with a 12 -ft straightedge. A summation of the measurements is shown below:

TRANSVERSE MEASUREMENTS

Slipform Lane, Interior

\begin{tabular}{|c|c|c|c|c|}
\hline $\begin{array}{l}\text { No. Readings } \\
\text { from } 42\end{array}$ & Maximum & Average & Readings & $\begin{array}{l}\text { Positions } \\
\text { Having } \\
\text { Readings }\end{array}$ \\
\hline $\begin{array}{l}\text { Straightedge } \\
\text { Positions }\end{array}$ & $\begin{array}{c}\text { Deviation } \\
\text { in. } \\
\end{array}$ & $\begin{array}{l}\text { Deviation } \\
\text { in. } \\
\end{array}$ & $\begin{array}{l}>1 / 4 \mathrm{in} . \\
\text { percent }\end{array}$ & $\begin{array}{l}>1 / 4 \mathrm{in} . \\
\text { percent }\end{array}$ \\
\hline 20 & $1 / 8$ & 0.12 & 0 & 0 \\
\hline
\end{tabular}


Slipform Lane, Edge

\begin{tabular}{ccccc}
$\begin{array}{c}\text { No. of } \\
\text { Straightedge } \\
\text { Positions }\end{array}$ & $\begin{array}{c}\text { Maximum } \\
\text { Deviation } \\
\text { in. }\end{array}$ & $\begin{array}{c}\text { Average } \\
\text { Deviation } \\
\text { in. }\end{array}$ & & $\begin{array}{c}\text { Edge } \\
\text { Deviations } \\
>1 / 4 \text { in. } \\
\text { percent }\end{array}$ \\
\cline { 1 - 1 } & $5 / 16$ & & 0.16 & 3
\end{tabular}

Fill-In Lane, Interior

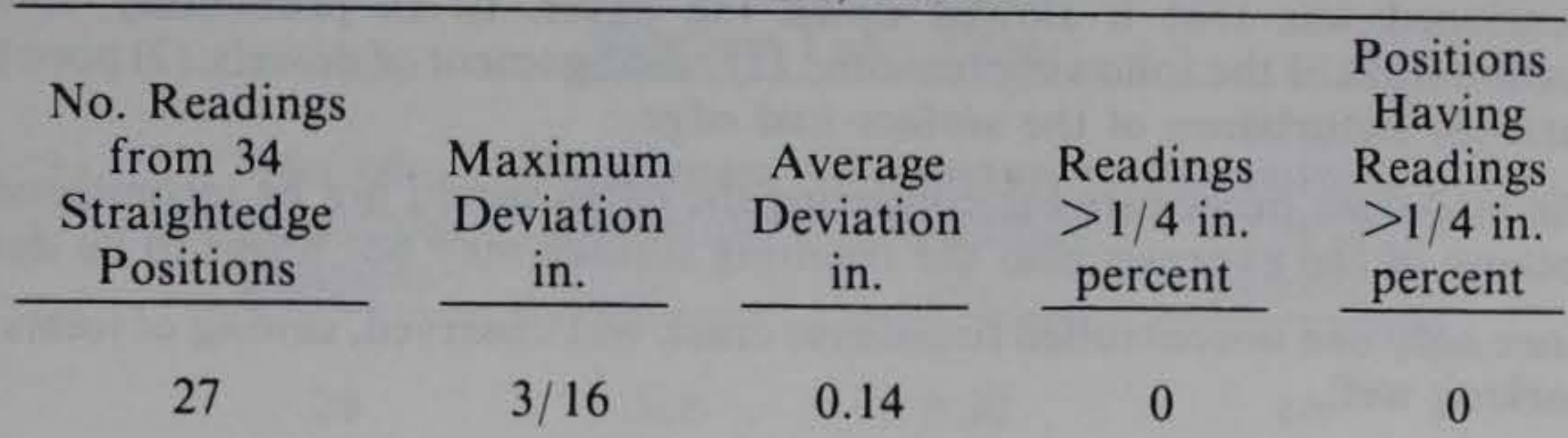

Fill-In Lane, Edge

\begin{tabular}{|c|c|c|c|}
\hline $\begin{array}{c}\text { No. of } \\
\text { Straightedge } \\
\text { Positions } \\
\end{array}$ & $\begin{array}{c}\text { Maximum } \\
\text { Deviation } \\
\text { in. } \\
\end{array}$ & $\begin{array}{c}\text { Average } \\
\text { Deviation } \\
\text { in. } \\
\end{array}$ & $\begin{array}{c}\text { Edge } \\
\text { Deviations } \\
>1 / 4 \text { in. } \\
\text { percent }\end{array}$ \\
\hline 34 & $1 / 2$ & 0.21 & 32 \\
\hline
\end{tabular}

LONGITUDINAL MEASUREMENTS

\begin{tabular}{|c|c|c|c|c|c|c|}
\hline $\begin{array}{l}\text { No. of Readings } \\
\text { from } 46 \\
\text { Straightedge } \\
\text { Positions }\end{array}$ & $\begin{array}{c}\text { Maximum } \\
\text { Devia- } \\
\text { tion } \\
\text { in. }\end{array}$ & $\begin{array}{l}\text { Average } \\
\text { Devia- } \\
\text { tion } \\
\text { in. }\end{array}$ & $\begin{array}{l}\text { Readings } \\
>1 / 8 \text { in. } \\
\text { percent }\end{array}$ & $\begin{array}{c}\text { Positions } \\
\text { Having } \\
\text { Readings } \\
>1 / 8 \text { in. } \\
\text { percent }\end{array}$ & $\begin{array}{l}\text { Readings } \\
>1 / 4 \text { in. } \\
\text { percent }\end{array}$ & $\begin{array}{c}\text { Positions } \\
\text { Having } \\
\text { Readings } \\
>1 / 4 \text { in. } \\
\text { percent }\end{array}$ \\
\hline 65 & $3 / 8$ & 0.14 & 26 & 37 & 1 & 2 \\
\hline
\end{tabular}

Note: Straightedge positions for transverse measurements:

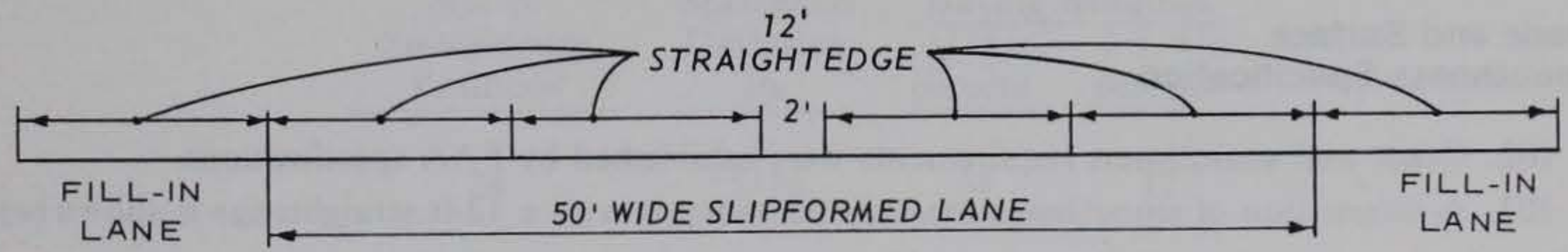

Longitudinal measurements: straightedge placed end to end. 
96. The following comments are based on discussion with personnel and observations made at the time of the inspection.

a. The side forms were pinched in at the top in an attempt to control edge slump. The edges looked adequate before being worked.

$b$. The surface finish obtained looked very good and required very little hand finishing.

c. The keyway formed along longitudinal joints looked good.

d. The alignment of the dowels appeared to be adequate. Why the procedure of inserting the dowels and tie bars in the plastic concrete was abandoned is uncertain. One reason mentioned was that it slowed down the paver. In all probability, it was one or a .combination of the following reasons: (1) misalignment of dowels; (2) poor bond of the tie bars; (3) disturbance of the surface and edge.

$e$. The elaborate procedure for correcting the edges would not be recommended, primarily because of the expense; also the resulting surface may not prove to be durable.

$f$. Since only one uncontrolled transverse crack was observed, sawing of joints appears to be working well.

\section{PROJECT 9}

97. On 24 January 1973, the construction procedures of slipform paving of a 16-in.-thick runway and taxiway were observed. Details of pavement construction are given in the following paragraphs.

\section{Pavement Description}

98. The pavement was 16-in.-thick PCC and was placed in two lifts with wire mesh reinforcing. The 150 - $\mathrm{ft}$-wide runway was formed in six 25 - $\mathrm{ft}$ lanes; and the 75 -ft-wide taxiway was formed in three 25 - $\mathrm{ft}$ pours.

\section{Base Course}

99. The base course consisted of 8 in. of cement-treated base material placed on a 6-in. layer of stabilized subgrade.

\section{Mix Design}

100. The mix was designed for $564 \mathrm{lb} / \mathrm{yd}^{3}$ of cement. The maximum aggregate size was $1-1 / 2 \mathrm{in}$. and the contractor tried to maintain a slump of $3 / 4 \mathrm{in}$.

\section{Paving Equipment}

101. The paving train consisted of a Maxon spreader, a CMI slipform paver, a tube float, and burlap drag unit. Horizontal and vertical alignment were controlled from stringlines.

\section{Grade and Surface Smoothness Specification}

102. Grade and smoothness requirements were established by FAA specifications.

103. A summation of smoothness measurements made with a 12-ft straightedge is shown below: 


\section{TRANSVERSE MEASUREMENTS}

Slipform Lane, Interior

\begin{tabular}{|c|c|c|}
\hline $\begin{array}{c}\text { No. of } \\
\text { Straightedge } \\
\text { Positions } \\
\end{array}$ & $\begin{array}{l}\text { Maximum } \\
\text { Deviation } \\
\text { in. } \\
\end{array}$ & $\begin{array}{c}\text { Positions Having } \\
\text { Readings }>1 / 4 \text { in. } \\
\text { percent }\end{array}$ \\
\hline 24 & $1 / 2$ & 8 \\
\hline
\end{tabular}

Slipform Lane, Edge

\begin{tabular}{ccccc}
$\begin{array}{c}\text { No. of } \\
\text { Positions } \\
24\end{array}$ & $\begin{array}{c}\text { Maximum } \\
\text { Deviation } \\
\text { in. }\end{array}$ & $\begin{array}{c}\text { Average } \\
\text { Deviation } \\
\text { in. }\end{array}$ & & $\begin{array}{c}\text { Edge } \\
\text { Deviations } \\
>1 / 4 \text { in. } \\
\text { percent }\end{array}$ \\
\cline { 1 - 1 } & $5 / 8$ & & 0.30 & 46
\end{tabular}

Fill-In Lane, Interior

\begin{tabular}{|c|c|c|}
\hline $\begin{array}{l}\text { No. of } \\
\text { Straightedge } \\
\text { Positions }\end{array}$ & $\begin{array}{l}\text { Maximum } \\
\text { Deviation } \\
\text { in. }\end{array}$ & $\begin{array}{c}\text { Positions Having } \\
\text { Readings }>1 / 4 \text { in. } \\
\text { percent }\end{array}$ \\
\hline 24 & $5 / 16$ & 4 \\
\hline
\end{tabular}

Fill-In Lane, Edge

\begin{tabular}{ccccc}
$\begin{array}{c}\text { No. of } \\
\text { Straightedge } \\
\text { Positions }\end{array}$ & $\begin{array}{c}\text { Maximum } \\
\text { Deviation } \\
\text { in. }\end{array}$ & $\begin{array}{c}\text { Average } \\
\text { Deviation } \\
\text { in. }\end{array}$ & $\begin{array}{c}\text { Edge } \\
\text { Deviations } \\
>1 / 4 \text { in. } \\
\text { percent }\end{array}$ \\
\cline { 1 - 1 } & $9 / 16$ & & 0.19 & 33
\end{tabular}

LONGITUDINAL MEASUREMENTS

Slipform Lane

\section{Positions}

No. of Maximum Having Readings

Straightedge Deviation $>1 / 8$ in. $>1 / 4$ in.

Positions $\quad$ in. percent percent

24

$5 / 16$

54

12 